\title{
Artigo Original / Original Paper \\ As tribos Vernonieae e Eupatorieae (Asteraceae) de Morro do Chapéu, Bahia, Brasil
}

The Vernonieae and Eupatorieae tribes (Asteraceae) from Morro do Chapéu, Bahia, Brazil

\author{
Mariana Guerra Staudt ${ }^{1,3,4}$ \& Nádia Roque $e^{2}$
}

\begin{abstract}
Resumo
Estudos acerca da composição florística ao longo da Cadeia do Espinhaço revelam a expressiva diversidade de Asteraceae, especialmente de Eupatorieae e Vernonieae, que são as tribos com o maior número de espécies. O objetivo deste estudo foi realizar o levantamento florístico e taxonômico das espécies pertencentes às tribos Vernonieae e Eupatorieae que ocorrem em Morro do Chapéu, Chapada Diamantina, Bahia. Foram realizadas seis viagens ao campo e visitadas as principais coleções dos herbários de referência para a Chapada Diamantina. A tribo Vernonieae está representada por 13 gêneros e 28 espécies, na qual Lepidaploa possui o maior número de espécies (6 spp.), seguido de Stilpnopappus e Vernonanthura, com quatro espécies cada. A tribo Eupatorieae apresenta 17 gêneros e 30 espécies, sendo Mikania e Acritopappus, com seis e cinco espécies respectivamente, os gêneros com maior riqueza, seguidos de Trichogonia (3 spp.). As espécies Acritopappus jacobaeus, Acritopappus santosii, Lapidia apicifolia, Scherya bahiensis, Stylotrichium edmundoi, Trichogonia tombadorensis e uma espécie nova pertencente ao gênero Stilpnopappus são endêmicas de Morro do Chapéu. São apresentadas chaves de identificação genérica e específica, descrições, comentários taxonômicos e materiais examinados para todas as espécies, além de fotos.
\end{abstract}

Palavras-chave: Cadeia do Espinhaço, Campo rupestre, Compositae, taxonomia.

\begin{abstract}
Studies dealing with the floristic composition of the Espinhaço Range corroborate the impressive diversity of Asteraceae, especially Eupatorieae and Vernonieae, which are the tribes with the largest number of species. The aim of this study was to carry out a floristic and taxonomic survey of the species belonging to the Vernonieae and Eupatorieae tribes which occur in Morro do Chapéu, Chapada Diamantina, Bahia. Six field trips were conducted and the main herbaria with the most important Chapada Diamantina collections were visited. Tribe Vernonieae is represented by 13 genera and 28 species. Lepidaploa (6 spp.) entails the highest number of species, followed by Stilpnopappus and Vernonanthura with four species each. For tribe Eupatorieae we found 17 genera and 30 species. Acritopappus and Mikania, with six and five species respectively, represent the richest genera, followed by Trichogonia (3 spp.). The species Acritopappus jacobaeus, Acritopappus santosii, Lapidia apicifolia, Scherya bahiensis, Stylotrichium edmundoi, Trichogonia tombadorensis and a new species belonging to the genus Stilpnopappus, are endemic to the Morro do Chapéu municipality. Keys to genera and species identification, descriptions, taxonomic comments and examined materials for all species are presented, as well as images.
\end{abstract}

Key words: Espinhaço Range, Campo rupestre, Compositae, taxonomy.

Veja material suplementar em <https://doi.org/10.6084/m9.figshare.11594181.v1>

\footnotetext{
${ }^{1}$ Universidade Estadual de Feira de Santana, Prog. Pós-graduação em Botânica, Depto. Ciências Biológicas, km 3, BR-116, 44031-460, Feira de Santana, BA, Brasil.

${ }^{2}$ Universidade Federal da Bahia, Inst. Biologia, Campus Universitário de Ondina, Rua Barão de Jeremoabo s/n, 40170-115, Salvador, BA, Brasil.

${ }^{3}$ ORCID: <https://orcid.org/0000-0001-8925-7029>

${ }^{4}$ Autor para correspondência: marianastaudt@gmail.com
} 


\section{Introdução}

Asteraceae é considerada uma das maiores famílias dentre as Angiospermas, com aproximadamente 25.037 espécies (Panero \& Crozier 2016), reunidas em cerca de 1.600-1.700 gêneros, representando $10 \%$ de toda a flora mundial (Funk et al. 2009). A família é reconhecida pelas flores que são arranjadas em capítulo, anteras sinânteras com apresentação secundária do grão de pólen e ovário ínfero bicarpelar com um óvulo basal ereto, que se desenvolve em uma cipsela geralmente com pápus (Funk et al. 2009; Roque \& Bautista 2008).

No Brasil são registradas 28 tribos representadas por 290 gêneros e 2.100 espécies, sendo 70 gêneros e 1.330 espécies endêmicas do Brasil, com ocorrência em todos os domínios fitogeográficos (BFG 2018).

Estudos sistemáticos da família Asteraceae na Cadeia do Espinhaço revelam a riqueza da sua flora, principalmente no que se refere às tribos Eupatorieae e Vernonieae, que juntas ocupam as primeiras posições em número de espécies, representando mais da metade das Asteraceae nas áreas estudadas (Harley \& Simmons 1986; Leitão-Filho \& Semir 1987; Hind 1995; Guedes \& Orge 1998; Pirani et al. 2003; Zappi et al. 2003; Hatschbach et al. 2006; Queiroz et al. 2006; Almeida 2008; Hind \& Miranda 2008; Moura \& Roque 2014; Roque et al. 2016; Campos et al. 2016; Staudt et al. 2017).

A tribo Vernonieae engloba 125 gêneros e mais de 1.500 espécies encontradas principalmente nas Américas e África, além da Ásia e Austrália (Keeley \& Robinson 2009). No Brasil, é a segunda maior tribo e está representada por 52 gêneros e 444 espécies (BFG 2018). Por sua vez, a tribo Eupatorieae é uma das mais diversas tribos nos Neotrópicos, com aproximadamente 2.400 espécies e 186 gêneros (King \& Robinson 1987; Hind \& Robinson 2007; Rivera et al. 2016; Roque et al. 2017), distribuídos principalmente do México até a América do Sul, com vários representantes na América do Norte e poucos no Velho Mundo (Bremer 1994). No Brasil, Eupatorieae é a tribo mais rica em gêneros (91) e espécies (616), seguida por Vernonieae, Heliantheae, Astereae e Senecioneae (BFG 2018).

A Cadeia do Espinhaço abrange aproximadamente $1.000 \mathrm{~km}^{2}$, na direção nortesul, desde a Serra de Jacobina, ao norte da Bahia, até a Serra de Ouro Branco, ao sul de Minas Gerais (Fig. 1). A região divide os domínios do Cerrado e da Mata Atlântica em sua porção centro-sul e também o Cerrado e a Caatinga em sua porção norte (Giulietti et al. 1987; Harley 1995). Na Cadeia do Espinhaço são reconhecidas ca. 125 gêneros e 500 espécies de Asteraceae e destes táxons, 10 gêneros e ca. 75 espécies são endêmicas da Chapada Diamantina na Bahia (Roque et al. 2016).

Considerando a riqueza de Asteraceae e o elevado número de espécies microendêmicas da Cadeia do Espinhaço, torna-se de grande relevância o desenvolvimento de novas pesquisas que revelem as especificidades e os endemismos, de forma a contribuir na definição do estado de conservação de suas espécies, na identificação de áreas prioritárias e no estabelecimento de estratégias para a conservação dos ambientes que se encontram em situação de risco. O município de Morro do Chapéu, área do presente estudo, é classificado como zona de extrema prioridade e mapeado como área insubstituível para a conservação na Chapada Diamantina, onde os enclaves únicos de caatinga e campo rupestre setentrional encontramse ameaçados (Maury 2002; Zappi 2008). Sendo assim, este estudo tem como objetivo apresentar o tratamento taxonômico das tribos Vernonieae e Eupatorieae de Morro do Chapéu, Bahia, contribuindo para ampliar o conhecimento da flora de Asteraceae e reforçar a importância de estudos florísticos e taxônomicos de grupos representativos e endêmicos da Cadeia do Espinhaço.

\section{Material e Métodos}

O município de Morro do Chapéu na Chapada Diamantina (Fig. 1) pertence a região semi-árida da Bahia e ocupa uma área de $5.920 \mathrm{~km}^{2}$. Sua posição geográfica confere-lhe características climáticas do tipo tropical, fortemente alteradas pela altitude, que varia de $480 \mathrm{~m}$ a $1.293 \mathrm{~m}$ (Rocha \& Costa 1995). Morro do Chapéu apresenta tipos vegetacionais bem distintos como caatinga, campo rupestre e floresta estacional semidecidual, bem como, vegetações de ecótonos e complexas áreas de transição, devido a altitude e a topografia local (França \& Melo 2013). O mapa apresentado na Fig. 1 foi gerado através do software $A r c G I S$, versão 10.0 (ESRI 2010).

Para o levantamento florístico foram realizadas seis viagens de coleta no período de novembro de 2014 a março de 2016, sendo contempladas as diferentes sazonalidades e variações pluviométricas. O procedimento adotado para as coletas foi através de caminhadas aleatórias que atingiram os acessos principais e secundários de 


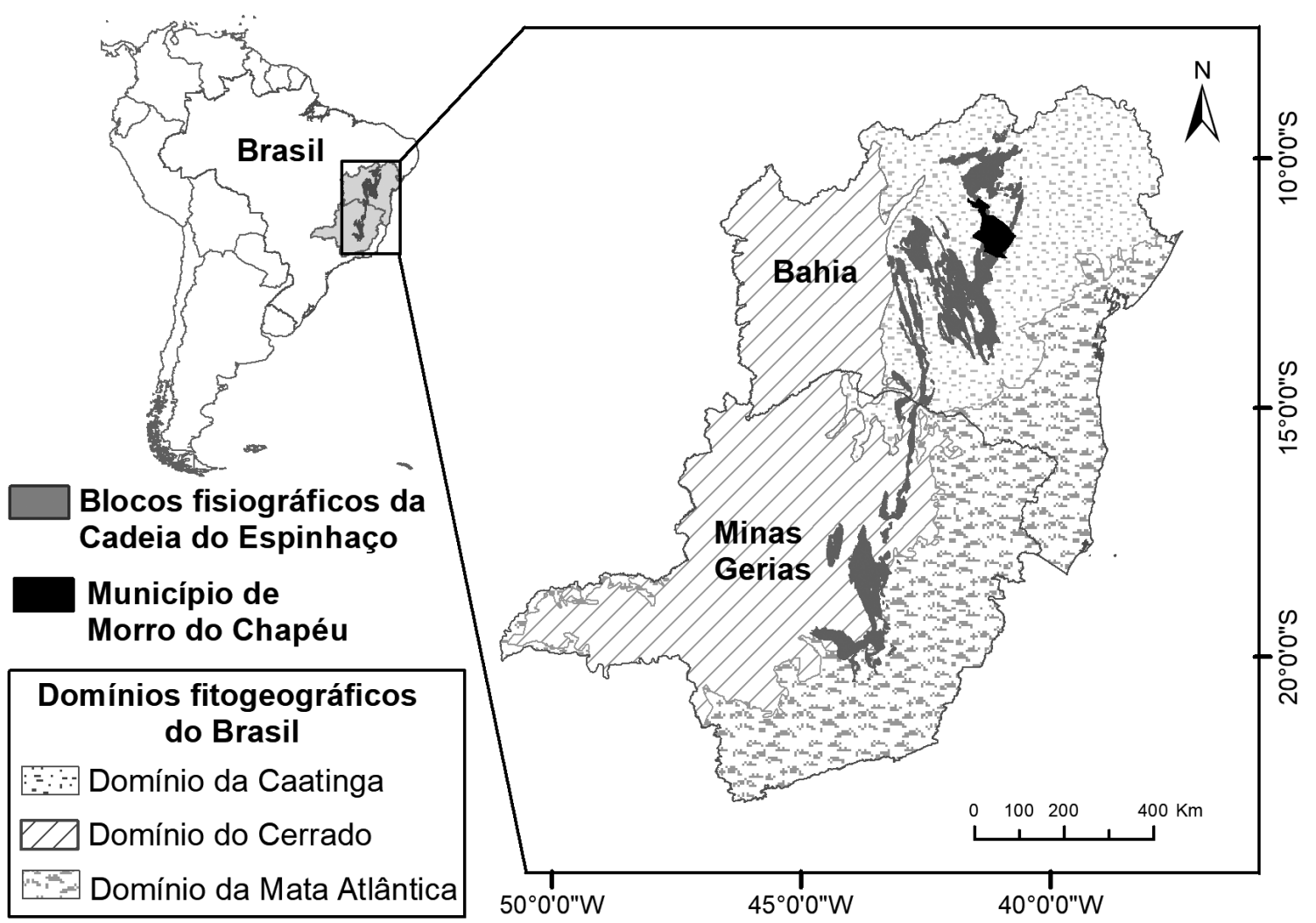

Figura 1 - Mapa da Cadeia do Espinhaço e de localização do município de Morro do Chapéu, Bahia, Brasil. Fonte: IBGE 2004, 2007; MMA 2007; CPRM 2010; Guimarães et al. 2012.

Figure 1 - Map showing the location of the municipality of Morro do Chapéu in the Espinhaço Range, Brazil. Source: IBGE 2004, 2007; MMA 2007; CPRM 2010; Guimarães et al. 2012.

estradas, trilhas e áreas circunvizinhas, abrangendo todas as fitofisionomias existentes na região.

Nas viagens supramencionadas foram observados dados sobre habitat, hábito e a fenologia das espécies. O material coletado e georreferenciado foi processado conforme as técnicas descritas por Peixoto \& Maia (2013), e depositado no Herbário ALCB, com o envio de duplicatas ao acervo do Herbário HUEFS.

Para as identificações e descrições dos táxons foram examinados os materiais coletados nas expedições a Morro do Chapéu e analisados os espécimes depositados nos Herbários: ALCB, CEPEC, HRB, HUEFS, R, RB, SP e SPF (acrônimos conforme Thiers, continuamente atualizado). Também foram utilizados protólogos, espécimes-tipo (exsicatas e fotos) e literatura específica (artigos, revisões, monografias e teses). A caracterização morfológica das espécies foi consoante às obras de Small (1919), Radford et al. (1974), Harris \& Harris (2001) e Beentje (2010) para a descrição dos caracteres vegetativos e, para os caracteres reprodutivos, utlizou-se Roque \& Bautista (2008) e Roque et al. (2009).

A apresentação das tribos Vernonieae e Eupatorieae está de acordo com Funk et al. (2009). Chaves de identificação genérica e específica são apresentadas e os gêneros e as respectivas espécies encontram-se em ordem alfabética e estão acompanhadas de descrições taxonômicas, materiais examinados, comentários diagnósticos e de distribuição geográfica e fotos. Para os gêneros monoespecíficos, somente a espécie é descrita.

\section{Resultados e Discussão}

Em Morro do Chapéu, Asteraceae está representada por 18 tribos, 72 gêneros e 119 espécies, sendo que $43 \%$ das espécies tem distribuição restrita a um único tipo de fitofisionomia (floresta estacional semidecidual, caatinga ou campo rupestre) (Staudt et al. 2017). Com 58 espécies registradas para Morro do Chapéu, Vernonieae e 
Eupatorieae são as tribos com maior diversidade, compondo $50 \%$ da flora local de Asteraceae.

A tribo Vernonieae está representada por 13 gêneros e 28 espécies. Lepidaploa (Cass.) Cass. possui o maior número de espécies (6 spp.), seguido de Stilpnopappus Mart. ex DC. e Vernonanthura H.Rob., com quatro espécies cada e juntos representam 50\% das espécies da tribo. Assim como o município de Jacobina (Moura \& Roque 2014), Morro do Chapéu apresentou ausência e baixa representatividade dos gêneros Lychnophora Mart. e Lessingianthus H.Rob. respectivamente, se comparado com outras áreas de cerrado e campo rupestre da Cadeia do Espinhaço, onde ambos os gêneros apresentam elevada diversidade (Giulietti et al. 1987; Hind 1995; Pirani et al. 2003; Zappi et al. 2003; Campos et al. 2016; Roque et al. 2016).

Para a tribo Eupatorieae foram encontrados 17 gêneros e 30 espécies e destas, 20\% são endêmicas de Morro do Chapéu. Mikania Willd. e Acritopappus R.M.King \& H.Rob. com seis e cinco espécies respectivamente, são os gêneros com maior riqueza, seguidos de Trichogonia Gardner, com três espécies. Mikania domina as primeiras posições em número de espécies na Cadeia do Espinhaço para a tribo (Giulietti et al. 1987; Hind 1995; Pirani et al. 2003; Zappi et al. 2003; Moura \& Roque 2014; Campos et al. 2016; Roque et al. 2016) e junto com Chromolaena DC., compreende mais de $45 \%$ da diversidade de espécies de Eupatorieae no Brasil, sendo muitas dessas espécies endêmicas do país (Rivera et al. 2016).

Dentre os gêneros registrados, seis são monoespecíficos (Albertinia Spreng., Bahianthus R.M.King \& H.Rob., Conocliniopsis R.M.King \& H.Rob., Lapidia Roque \& S.C.Ferreira, Prolobus R.M.King \& H.Rob. e Scherya R.M.King \& H.Rob.) e dentre os táxons encontrados, 19 (32,7\%) são endêmicos da Bahia. As espécies da tribo Eupatorieae, Acritopappus jacobaeus Bautista, Rodr.Oubinã \& S.Ortiz, Acritopappus santosii R.M.King \& H.Rob., Lapidia apicifolia Roque \& S.C.Ferreira, Scherya bahiensis R.M.King \& H.Rob., Stylotrichium edmundoi G.M.Barroso, Trichogonia tombadorensis R.M.King \& H.Rob. e, uma espécie inédita da tribo Vernonieae, Stilpnopappus sp. nov. são, até o momento, endêmicas para o município.

Stilpnopappus suffruticosus Gardner é registrada como nova ocorrência para o estado da Bahia e encontra-se na Lista Vermelha de plantas ameaçadas, assim como as espécies Paralychnophora harleyi (H.Rob.) D.J.N.Hind,
Stilpnopappus semirianus R.Esteves, Stylotrichium corymbosum (DC.) Mattf. e S. edmundoi (Nakajima et al. 2013).

As tribos Vernonieae e Eupatorieae predominam nos campos rupestres de Morro do Chapéu, sendo 34\% das espécies restritas para essa fitofisionomia na região, destacando-se as espécies endêmicas da Cadeia do Espinhaço (Cyrtocymura harleyi (H.Rob.) H.Rob., Lepidaploa lilacina (Mart. ex DC.) H.Rob. e Mikania elliptica DC.) e da Chapada Diamantina (Acritopappus prunifolius R.M.King \& H.Rob., Agrianthus empetrifolius Mart. ex DC., Lepidaploa bahiana H.Rob., Lepidaploa tombadorensis (H.Rob.) H.Rob., P. harleyi, S. corymbosum, S. semirianus e Stilpnopappus tomentosus Mart. ex DC.).

Neste sentido, é importante ressaltar que mesmo com a grande diversidade e elevado grau de endemismos, as espécies de Asteraceae, especialmente de Eupatorieae e Vernonieae (sete espécies endêmicas, sendo dois gêneros da tribo Eupatorieae (Lapidia e Scherya) monoespecíficos), vem sofrendo ameaças contantes nas áreas de campo rupestre de Morro do Chapéu, tanto com a diminuição da população quanto na perda de habitat, através da intensa extração de areia e da expansão de áreas para a agricultura.

\section{Tratamento taxonômico} da tribo Vernonieae

\section{Vernonieae Cass.}

Vernonieae caracteriza-se pelas folhas geralmente alternas e simples; inflorescência em cimeiras, corimbiformes ou paniculiformes, capítulos discóides, homógamos, invólucro campanulado a cilíndrico, brácteas involucrais multisseriadas e imbricadas, persistentes ou decíduas, receptáculo plano a sub-convexo, glabro a paleáceo; capítulos frequentemente agrupados em capítulos secundários (sincefalia); flores de 1 a 400, tubulosas, actinomorfas, raramente zigomorfas, bissexuais, corola roxa-avermelhada a lilás, rosa, azulada a alva e raro amarela, anteras usualmente calcaradas, ramos do estilete com tricomas se prolongando abaixo do ponto de bifurcação, ápice agudo ou obtuso; cipsela 3-20 costada, pápus geralmente duplo, série externa geralmente mais curta e paleácea, e interna cerdosa, ou com duas ou mais séries de elementos similares, geralmente cerdosos, podendo conter elementos espiralados, raramente coroniforme ou ausente (Robinson 1999; Keeley \& Robinson 2009). 
Chave de identificação dos gêneros da Tribo Vernonieae no Morro do Chapéu, Bahia, Brasil

1. Ramos fistulosos; lâmina foliar pinatipartida, amplexicaule

4. Chresta

1'. Ramos não fistulosos; lâmina foliar inteira, não amplexicaule.

2. Brácteas involucrais fundidas na base e receptáculo profundamente alveolado, envolvendo parcialmente a cipsela ..... 1. Albertinia

2'. Brácteas involucrais livres e receptáculo de outras formas, não envolvendo a cipsela.

3. Arbusto escandente; ramos quadrangulares; brácteas involucrais decíduas

11. Piptocarpha

3'. Ervas, subarbustos, arbustos eretos ou árvores; ramos cilíndricos; brácteas involucrais persistentes.

4. Capítulos com 1-4 flores.

5. Arbustos ou árvores; pápus 3-4 séries

7. Eremanthus

5'. Ervas rosuladas; pápus 1-2 séries

6. Elephantopus

4'. Capítulos com 5 ou mais flores.

6. Capitulescências em sincéfalos (capítulos secundários) que pendem tardiamente. 10. Paralychnophora

6'. Capítulos sésseis ou pedunculados e capitulescências de outras formas.

7. Ervas; brácteas subinvolucrais foliáceas circundando o capítulo; receptáculo alveolado-aristado.

8. Brácteas involucrais com ápice aristado; capítulos com ca. 155 flores; pápus unisseriado, cerdoso-barbelado; cipsela cilíndrica.

3. Centratherum

8'. Brácteas involucrais com ápice agudo, acuminado ou apiculado; capítulos com 24-60 flores; pápus bisseriado, paleáceo; cipsela obcônica....

12. Stilpnopappus

7'. Subarbustos, arbustos ou árvores; capítulos não circundados por brácteas subinvolucrais foliáceas; receptáculo fimbriado, alveolado.

9. Capitulescência glomeruliforme; tricomas estrelados e pontuações glandulares em ambas as faces da lâmina foliar.

2. Blanchetia

9'. Capitulescência paniculiforme ou cimoso-escorpióide; sem tricomas estrelados e pontuações glandulares na lâmina foliar.

10. Capitulescência paniculiforme ou tirsóide ...

13. Vernonanthura

10'. Capitulescência em cimeiras escorpióides.

11. Capítulos dispostos em duas séries (subduplicadas) em ramos terminais

5. Cyrtocymura

11'. Capítulos em uma série em ramos terminais.

12. Receptáculo alveolado; cipsela com pontuações glandulares 8. Lepidaploa

12'. Receptáculo não alveolado; cipsela sem pontuações glandulares 9. Lessingianthus

1. Albertinia Spreng.

1.1. Albertinia brasiliensis Spreng., Neue Entdeck. Pflanzenk. 2: 133. 1821.

Fig. 2a

Arbusto escandente, 3-5 m alt. Ramos cilíndricos, estriados, glabrescentes. Folhas alternas, pecioladas, pecíolo ca. $0,5 \mathrm{~cm}$ compr.; lâmina foliar 2,2-4,7 × 1,4-3 cm, membranácea, discolor, elíptica, ápice agudo a acuminado, margem inteira, base atenuada, face adaxial estrigosa, face abaxial serícea, tricomas glandulares sésseis em ambas as faces. Capitulescência corimbiforme, terminal. Capítulos pedunculados, pedúnculo $0,5-1,5 \mathrm{~cm}$ compr. Invólucro $6-7 \times$ 7-8 mm, campanulado, multisseriado; brácteas involucrais fundidas na base, 40, 3-4 séries, sub-iguais, externas ovadas, internas lanceoladas, $1,2-2,8 \times 0,5-1,2 \mathrm{~mm}$, ápice acuminado, margem inteira, base concrescida, tomentosas, esverdeadas. Receptáculo profundamente alveolado, envolvendo parciamente a cipsela, glabro. Flores ca. 45, corola 5-7 mm compr., rósea a alva, glabra, tubo $2-3$ mm compr., limbo ca. $1 \mathrm{~mm}$ compr., lacínias $2-3$ 
mm compr. Antera 2,5-2,8 mm compr., apêndice do conectivo agudo, 0,6-0,8 mm compr., base calcarada. Estilete ca. $8 \mathrm{~mm}$ compr., alvo, ramos do estilete ca. $2 \mathrm{~mm}$ compr. Cipsela 1-1,4 mm compr., obcônica, serícea, 10-costada; carpopódio inconspícuo. Pápus bisseriado, série externa paleácea, 1,8-2,8 mm compr., série interna cerdosa barbelada, 4-4,5 mm compr., persistentes, creme a ferrugíneo.

Material selecionado: próximo ao Ventura, 11³9'07’'S, 4057'42”W, 765 m, 18.XI.1999, E. Melo et al. 3185 (CEPEC, HUEFS).

Albertinia é um gênero monoespecífico endêmico do Brasil (BFG 2018; Loeuille 2011). Albertinia brasiliensis é reconhecida pelo hábito arbustivo escandente, brácteas involucrais fundidas na base e receptáculo profundamente alveolado, que envolve parcialmente a cipsela, deixando somente o pápus exposto (Ogasawara \& Roque 2015). Em Morro do Chapéu foi encontrada em área de caatinga.

\section{Blanchetia DC.}

O gênero caracteriza-se por apresentar capítulos ovóides e dois tipos de tricomas: simples, escuros e não ramificados ou estrelados com braços bifurcados (Loeuille et al. 2014). É representado por apenas duas espécies, Blanchetia coronata (G.M.Barroso) Loeuille \& Pirani e Blanchetia heterotricha DC., que são endêmicas do nordeste do Brasil, com registros para a Caatinga e a Mata Atlântica (BFG 2018). No município de Morro do Chapéu foi encontrada apenas uma espécie.

2.1. Blanchetia heterotricha DC., Prodr. 5: 75. 1836.

Fig. $2 b$

Arbusto ca. 1,5 m alt. Ramos cilíndricos, cinéreo-tomentosos a glabrescentes com tricomas tectores estrelados. Folhas alternas, pecioladas, pecíolo 0,2-0,5 cm compr.; lâmina foliar 3,3-8 $\times$ 2,2-3,4 cm, membranácea, fortemente discolor, oblanceolada a obovada, ápice obtuso a agudomucronado, margem inteira a denticulata, base cuneada, face adaxial esparsamente cinéreotomentosa a glabrescente, face abaxial densamente cinéreo-tomentosa, com tricomas tectores estrelados e pontuações glandulares em ambas as faces. Capitulescência glomeruliforme, axilar. Capítulos sésseis a pedunculados, pedúnculo ca. 0,2 mm compr. Invólucro 4,5-6 × 4,5-5 mm, campanulado a globoso, imbricado, multisseriado; brácteas involucrais 23-25, 5-6 séries, externas $2-2,8 \times 1,1-1,4 \mathrm{~mm}$, ovadas a oblongas, internas
4-4,5 × 1-1,2 mm, lanceoladas, ápice agudo a cuspidado, margem inteira, esverdeadas com ápice vináceo, seríceas. Receptáculo plano, fimbriado. Flores 6-10, corola 4-6,5 mm compr., alva, glabra, tubo 2,2-3,5 mm compr., lacínias lanceoladas que se estendem até o tubo, 2,8-3 mm compr. Antera 2,2-2,4 mm compr., apêndice do conectivo agudo, 0,3-0,4 mm compr. Estilete 3,5-4,2 mm compr., lilás, ramos do estilete $1-1,2 \mathrm{~mm}$ compr., ápice agudo. Cipsela 1,2-2 mm compr., obcônica, glabra, 10-costada; carpopódio inconspícuo. Pápus 1,4-3,2 mm compr., bisseriado, paleáceo, desigual, caduco, alvo.

Material selecionado: saída do Ventura para Santa

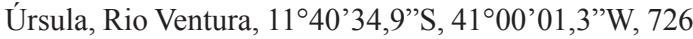
m, 16.VI.2015, M.G. Staudt et al. 36 (ALCB, HUEFS).

Blanchetia heterotricha pode ser reconhecida pela capitulescência axilar, indumento cinéreotomentoso e presença de tricomas estrelados nos ramos e na lâmina foliar. A espécie possui distribuição restrita para o nordeste (Alagoas, Bahia, Paraíba, Pernambuco e Sergipe) (BFG 2018). Na região de estudo foi encontrada apenas em floresta estacional semidecidual.

\section{Centratherum Cass.}

Centratherum apresenta hábito herbáceo a subarbustivo, capítulos pedunculados, solitários no ápice dos ramos e subentendidos por brácteas subinvolucrais foliáceas, invólucro campanulado e pápus unisseriado cerdoso (Kirkman 1981). No Brasil há registro de duas espécies, sendo Centratherum punctatum Cass., amplamente distribuída (BFG 2018). Em Morro do Chapéu somente esta espécie foi coletada.

3.1. Centratherum punctatum Cass., Dict. Sci. Nat.7: 384. 1817. Fig. 2c

Erva 10-20 cm alt. Ramos cilíndricos, estriados, vilosos. Folhas alternas, pecioladas, pecíolo 0,4-0,7 cm compr.; lâmina foliar 1-3,5 × 0,5-2 cm, membranácea, discolor, elíptica a oblanceolada, ápice mucronado, margem serreada, base atenuada, faces adaxial e abaxial pubescentes com tricomas glandulares sésseis. Capítulos solitários, terminais, sésseis a pedunculados, pedúnculo até $0,3 \mathrm{~mm}$ compr.; brácteas subinvolucrais foliáceas 6-7, na base do capítulo, persistentes, pubescentes, com tricomas glandulares sésseis. Invólucro 0,9 $\times 1 \mathrm{~cm}$, campanulado, imbricado, multisseriado; brácteas involucrais ca. 70, 4-5 séries, externas 3-4 × 0,6-1 mm, ovadas, internas 5-7 × 1,4-1,7 $\mathrm{mm}$, oblanceoladas, ápice aristado, margem inteira, 

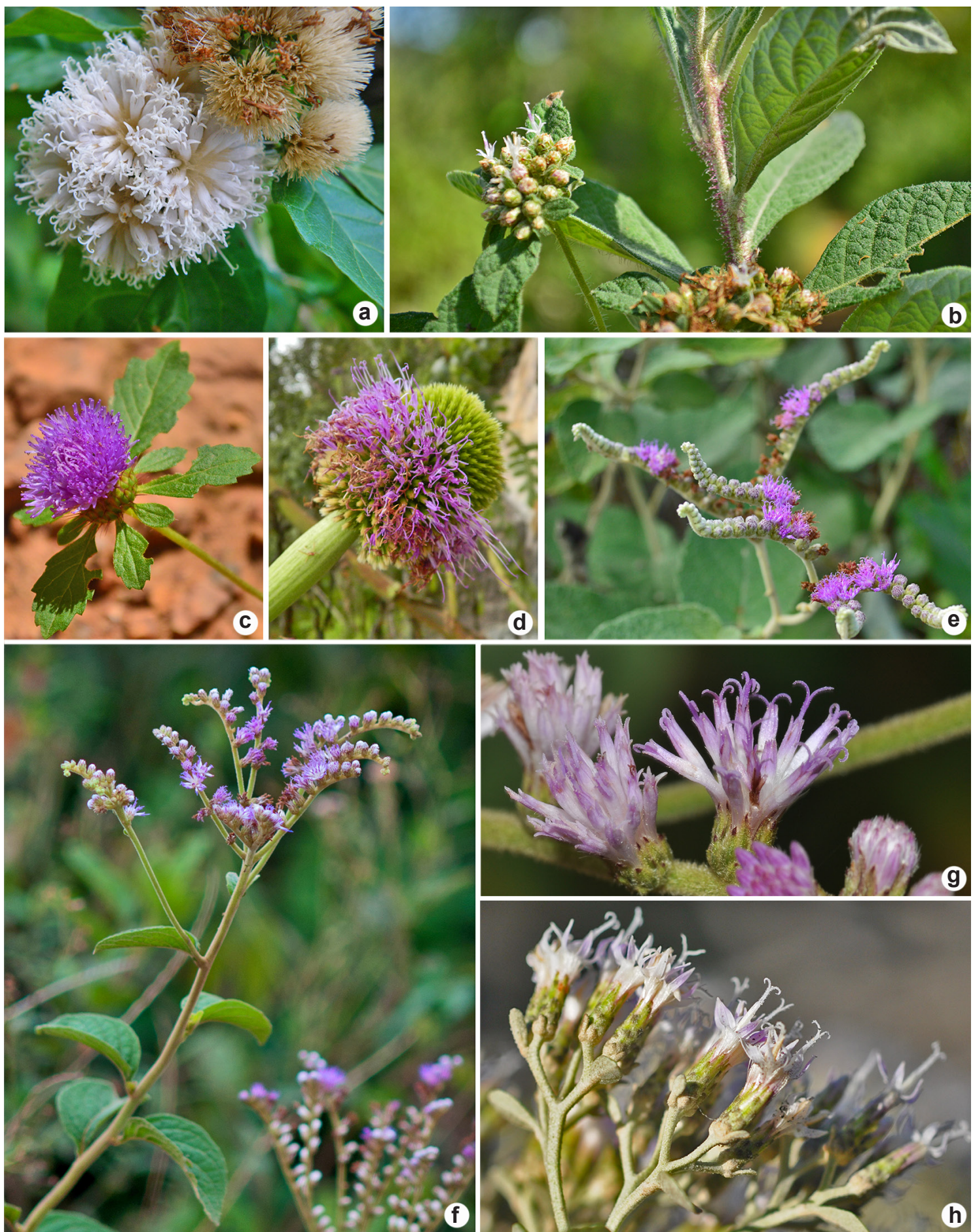

Figura 2 - a. Albertinia brasiliensis. b. Blanchetia heterotricha. c. Centratherum punctatum. d. Chresta pacourinoides. e. Cyrtocymura harleyi. f, g. Cyrtocymura scorpioides. h. Eremanthus capitatus (a. H. Ogasawara; b, c, e. A. Gandara; d. L. Campos; f, g. L. Pataro; h. L. Barres).

Figure 2 - a. Albertinia brasiliensis. b. Blanchetia heterotricha. c. Centratherum punctatum. d. Chresta pacourinoides. e. Cyrtocymura harleyi. f, g. Cyrtocymura scorpioides. h. Eremanthus capitatus (a. H. Ogasawara; b, c, e. A. Gandara; d. L. Campos; f, g. L. Pataro; h. L. Barres). 
esverdeadas com ápice vináceo, pubérulas com tricomas glandulares sésseis. Receptáculo plano, alveolado, aristado. Flores ca. 155, corola 7,5-8,3 mm compr., lilás, tubo 3,5-4 mm compr., piloso com tricomas glandulares sésseis, limbo 1-2,5 mm compr., lacínias 1,4-1,8 mm compr. Antera 1,8-2,1 mm compr., apêndice do conectivo ca. $0,3 \mathrm{~mm}$ compr., apiculado, base calcarada. Estilete 3,5-5 mm compr., ramos do estilete lineares, ápice acuminado, lilás. Cipsela 0,7-2 mm compr., cilíndrica, com tricomas glandulares sésseis, 10-costada; carpopódio inconspícuo. Pápus 1,3-1,6 mm compr., uniserriado, cerdoso-barbelado, caduco, creme.

Material selecionado: Rio Ventura, $11^{\circ} 40^{\prime} 36,4$ "S, 4059'58,5”W, 703 m, 16.IX.2015, M.G. Staudt et al. 104 (ALCB, HUEFS).

Centratherum punctatum pode ser reconhecida pela lâmina foliar serreada, pubescente em ambas as faces, capítulo solitário, terminal, circundado por brácteas subinvolucrais foliáceas, invólucro multisseriado e pápus cerdoso-barbelado, caduco. A espécie é ruderal e amplamente distribuída na América do Sul (Kirkman 1981). No Brasil ocorre em vegetação de caatinga, floresta estacional semidecidual, campo rupestre e cerrado em todas as regiões do país (BFG 2018). Em Morro do Chapéu foi encontrada em áreas antropizadas, campos rupestres, caatinga e floresta estacional decidual.

\section{Chresta Vell. ex DC.}

O gênero caracteriza-se pelo hábito herbáceo, capitulescência longo-pedunculada, terminal com capítulos secundários ( sincefalia) e 2-12 flores por capítulo. No Brasil há registro de 15 espécies que são amplamente distribuídas nos domínios da Caatinga, Cerrado e Mata Atlântica (BFG 2018). Em Morro do Chapéu há registro de apenas uma espécie.

4.1. Chresta pacourinoides (Mart. ex DC.) Siniscalchi \& Loeuille, Phytoneuron 2014-8: 6. 2014.

Fig. $2 \mathrm{~d}$

Erva ereta, 0,5-1,5 m alt. Ramos fistulosos, cilíndricos, estriados, vilosos a glabrescentes.
Folhas alternas, sésseis; lâmina foliar 9-22 × 3,5-7,5 cm, membranácea, concolor, pinatipartida, ápice agudo, margem denteada, base amplexicaule, face adaxial pilosa a glabrescente e abaxial vilosa com tricomas glandulares sésseis. Capitulescência em sincéfalos (capítulos secundários), terminal. Capítulos sésseis. Invólucro $0,4-0,5 \times 0,2-0,3$ $\mathrm{mm}$, cilíndrico, imbricado; brácteas involucrais 7-10, 3 séries, externas $7 \times 1-1,5 \mathrm{~mm}$, lanceoladas, internas $8-11 \times 0,8-1 \mathrm{~mm}$, estreito-lanceoladas, ápice longo acuminado a aristado, margem denticulada, esverdeadas com base castanha, glabras. Receptáculo plano, glabro. Flores ca. 2, corola longo tubulosa, ca. $12 \mathrm{~mm}$ compr., lilás a roxa, glabra, tubo ca. $6 \mathrm{~mm}$ compr., limbo ca. $2 \mathrm{~mm}$ compr., lacínias ca. $4 \mathrm{~mm}$ compr. Antera ca. $2 \mathrm{~mm}$ compr., apêndice do conectivo ca. 0,4 $\mathrm{mm}$ compr., obtuso. Estilete ca. $14 \mathrm{~mm}$ compr., ramos do estilete lineares, ca. $4 \mathrm{~mm}$ compr., lilás. Cipsela 3-4 mm compr., cilíndrica, pubescente a glabrescente, 10-costada; carpopódio anuliforme. Pápus bisseriado, série externa ca. $1 \mathrm{~mm}$ compr., estreito-paleáceo, persistente, série interna 6-8 mm compr., cerdoso-barbelado, caduco, creme.

Material examinado: Fazenda Jaboticaba, $11^{\circ} 28^{\prime} 18^{\prime \prime}$, 41 13 '56”W, 1115 m, 9.IX.2006, J.M. Gonçalves et al. 124 (HUEFS).

Chresta pacourinoides pode ser reconhecida pela lâmina foliar pinatífida com base amplexicaule e numerosos capítulos unidos formando um sincéfalo. A espécie é amplamente distribuída na Caatinga, nos estados do nordeste (BFG 2018). Em Morro do Chapéu foi encontrada em campo rupestre.

\section{Cyrtocymura H.Rob.}

Cyrtocymura apresenta capitulescência em cimeira escorpióide e capítulos sésseis, geralmente sem brácteas foliáceas na base (Robinson 1987). O gênero inclui seis espécies, distribuídas pelo México, América Central, Antilhas e América do Sul: Brasil e Bolívia (Robinson 1987; Keeley \& Robinson 2009). No Brasil, está representado por quatro espécies (BFG 2018) e em Morro do Chapéu são registradas duas espécies.

\section{Chave de identificação das espécies de Cyrtocymura no Morro do Chapéu, Bahia, Brasil}

1. Ramos angulados, lanosos; lâmina foliar ovada, ápice obtuso a arredondado, margem crenada, base arredondada a cordada, cartácea, face abaxial lanosa; flores 19-20.. 5.1. Cyrtocymura harleyi

1'. Ramos estriados, seríceos; lâmina foliar lanceolada, ápice agudo a mucronado, margem inteira a denticulada, base atenuada, membranácea, face abaxial serícea; flores 21-30 .... 
5.1. Cyrtocymura harleyi (H.Rob.) H.Rob., Proc. Biol. Soc. Washington 100(4): 852. 1987.

Fig. 2e

Arbusto 0,6-1,5 m alt. Ramos cilíndricos, angulados, lanosos. Folhas alternas, pecioladas, pecíolo 1-3,5 cm compr.; lâmina foliar 4-10 $\times 2,5-5 \mathrm{~cm}$, cartácea, discolor, ovada, ápice obtuso a arredondado, margem crenada, base arredondada a cordada; face adaxial serícea e face abaxial lanosa. Capitulescência em cimeira escorpióide. Capítulos sésseis, dispostos em duas séries (subduplicadas), decíduos. Invólucro 3,5-4 $\times 3-3,5 \mathrm{~mm}$, campanulado; brácteas involucrais 20-26, 4-5 séries, externas $1,8-2,1 \times 0,9-1 \mathrm{~mm}$, ovadas, internas 3-3,2 $\times 0,8-1 \mathrm{~mm}$, lanceoladas, ápice agudo, margem inteira, esverdeadas, face adaxial serícea e face abaxial lanosa, ambas com tricomas glandulares sésseis. Receptáculo plano, fimbriado. Flores 19-20, corola 3,8-4,3 mm compr., lilás, com tricomas glandulares sésseis, tubo $1,5 \mathrm{~mm}$ compr., limbo $0,8-1,2 \mathrm{~mm}$ compr., lacínias 1,3 mm compr., seríceas. Antera 1,2-1,4 $\mathrm{mm}$ compr., apêndice do conectivo 0,3-0,4 $\mathrm{mm}$ compr., obtuso, base arredondada. Estilete 2,6-3,3 mm compr., papilosa, lilás, ramos do estilete lineares, 1-1,2 mm compr., ápice agudo. Cipsela 1-1,2 mm compr., cilíndrica a obcônica, serícea, 10-costada; carpopódio anuliforme. Pápus bisseriado, cerdoso-barbelado, série externa 0,3-0,4 mm compr., persistente, série interna 2,5-3 mm compr., decíduo, alvo.

Material selecionado: Cachoeira do Ferro Doido,

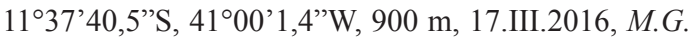
Staudt et al. 132 (ALCB, HUEFS).

A espécie é facilmente reconhecida por apresentar ramos e lâmina foliar lanosa, discolor, base arredondada a cordada, margem crenulada a erosa (Ogasawara \& Roque 2015). Encontrase com flores e frutos durante todo o ano. Cyrtocymura harleyi é endêmica do Brasil com distribuição restrita aos estados da Bahia e de Minas Gerais, onde ocorre na Caatinga, Cerrado e campos rupestres (Ogasawara \& Roque 2015). Tem Morro do Chapéu como localidade-tipo e é encontrada formando grandes populações nos campos rupestres da região.

5.2. Cyrtocymura scorpioides (Lam.) H.Rob., Proc. Biol. Soc.Washington 100(4): 852-853. 1987.

Fig. 2f,g

Subarbusto decumbente $0,5-2,5 \mathrm{~m}$ alt. Ramos cilíndricos, estriados, seríceos a pubescentes. Folhas alternas, pecioladas, pecíolo 0,9-1,6 cm compr.; lâmina foliar 8-12 × 2,7-6,2 cm, membranácea, discolor, lanceolada, ápice agudo a mucronado, raramente acuminado, margem inteira a denticulata, base atenuada, face adaxial estrigosa a glabrescente, face abaxial serícea, ambas com tricomas glandulares sésseis. Capitulescência em cimeira escorpióide. Capítulos sésseis, dispostos em duas séries (subduplicadas), decíduos. Invólucro 5,3-6 × 5,5-6 $\mathrm{mm}$, campanulado, imbricado; brácteas involucrais 26-29, 3-4 séries, externas $1,8-3,5 \times 0,8-1 \mathrm{~mm}$, ovadas, internas 5 $\times 0,4 \mathrm{~mm}$, oblanceolada a lanceolada, ápice agudo a acuminado, margem inteira, esverdeadas com ápice vináceo, face abaxial serícea. Receptáculo plano, fimbriado. Flores 21-30, corola 4,8-5,9 mm compr., lilás a alva, glabra, tubo $1,1-1,5 \mathrm{~mm}$ compr., limbo 2,3-2,5 mm compr., lacínias, 1,6-1,9 $\mathrm{mm}$ compr. Antera 2-2,4 mm compr., apêndice do conectivo $0,6-0,8 \mathrm{~mm}$ compr., acuminado, base cordada. Estilete 5,3-6,9 mm compr., ramos do estilete ca. 1,7 mm compr., ápice agudo, lilás. Cipsela 0,6-1 mm compr., obcônica, serícea, 10-costada; carpopódio simétrico, anuliforme. Pápus bisseriado, série externa paleácea, 0,7-1 $\mathrm{mm}$ compr., série interna cerdosa-barbelada, ca. 4,8 mm compr., alvo.

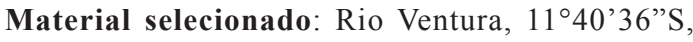
4059’58”'W, 703 m, 16.IX.2015, M.G. Staudt et al. 103 (ALCB, HUEFS).

Segundo Ogasawara \& Roque (2015), Cyrtocymura scorpioides apresenta características da lâmina foliar em comum com a espécie Cyrtocymura mattos-silvae (H.Rob.) H.Rob., e pode ser diferenciada por apresentar brácteas involucrais com ápice agudo (vs. flageliforme) e com tricomas no ápice da face adaxial ( $v s$. glabra). A espécie ocorre na América Central e do Sul e possui ampla distribuição no Brasil (Robinson 1987), em áreas de Mata atlântica, restinga, Caatinga, Cerrado e em locais antropizados (BFG 2018). Em Morro do Chapéu foi encontrada em campo rupestre, caatinga e bordas de mata.

\section{Elephantopus L.}

O gênero pode ser reconhecido pelo hábito herbáceo, capítulo subentendido por brácteas foliáceas e invólucro composto por quatro pares de brácteas e capítulos com 2-4 flores. Possui ca. 28 espécies distribuídas no leste da América do Norte e nos trópicos (Keeley \& Robinson 2009). No Brasil há registro de sete espécies, sendo que três delas ocorrem na Bahia (BFG 2018) e duas em Morro do Chapéu. 


\section{Chave de identificação das espécies de Elephantopus no Morro do Chapéu, Bahia, Brasil}

1. Brácteas cordiformes na base dos capítulos; pápus unisseriado, cerdoso....... 6.1. Elephantopus mollis

1’. Brácteas estreito-lanceoladas na base dos capítulos; pápus bisseriado, paleáceo. 6.2. Elephantopus hirtiflorus

6.1. Elephantopus hirtiflorus DC., Prodr. 5: 86. 1836.

Erva $50-80 \mathrm{~cm}$ alt. Ramos cilíndricos, com estrias vináceas, tricomas tectores simples e tricomas glandulares sésseis. Folhas alternas, rosuladas, sésseis; lâmina foliar 4,4-6,4 × 1,3-1,8 $\mathrm{cm}$, cartácea, discolor, lanceolada, ápice agudo, margem inteira, levemente revoluta, base cuneada, faces adaxial e abaxial densamente velutinas. Capitulescência glomeruliforme. Capítulos 20 por glomérulo, sésseis, subentendidos por brácteas estreito-lanceoladas. Invólucro 11-14 × 3-4 mm, cilíndrico; brácteas involucrais 8 , imbricadas, bisseriadas, 4 externas e 4 internas, externas $8-8,5 \times 2-2,5 \mathrm{~mm}$, internas $11-14 \times 3,2-3,8 \mathrm{~mm}$, lanceoladas, ápice acuminado, margem inteira, esverdeadas com ápice vináceo, face adaxial glabra e face abaxial com indumento gríseo-velutineo. Receptáculo plano, glabro. Flores 4, corola ca. 1 cm compr., alva, glabra, tubo ca. $6 \mathrm{~mm}$ compr., limbo ca. 1,5 mm compr., lacínias ca. 2,5 mm compr., densamente velutinas. Antera ca. 2,3 $\mathrm{mm}$ compr., apêndice do conectivo obtuso, 0,2 $\mathrm{mm}$ compr., base calcarada. Estilete ca. $11 \mathrm{~mm}$ compr., alvo, ramos do estilete ca. $2 \mathrm{~mm}$ compr., ápice agudo, piloso. Cipsela 3-5 $\mathrm{mm}$ compr., cilíndrica, serícea com tricomas glandulares sésseis, 10-costada; carpopódio cilíndrico, decorrente. Pápus bisseriado com 5 páleas em cada série, série externa 1,2-1,6 mm compr., série interna 5,5-6 mm compr., alvo.

Material selecionado: Cachoeira Ferro Doido, 11'37'38"S, 4100'03"W, 902 m, 18.VI.2015, M.G. Staudt et al. 68 (ALCB, HUEFS).

Elephantopus hirtiflorus caracteriza-se por apresentar lâmina foliar lanceolada, pápus bisseriado, com cinco páleas curtas e cinco páleas longas. A espécie é endêmica do Brasil e amplamente distribuída no nordeste e em Minas Gerais, Rio de Janeiro e Goiás em áreas antropizadas, campo rupestre, Cerrado, restinga e Floresta Ombrófila Mista (BFG 2018). Em Morro do Chapéu foi coletada sob afloramento rochoso em área de campo rupestre.
6.2. Elephantopus mollis Kunth, Nov. Gen. Sp. 4:20-21. 1818.

Erva ca. $90 \mathrm{~cm}$ alt. Ramos cilíndricos, estriados, tricomas tectores simples e glandulares sésseis. Folhas alternas, rosuladas, sésseis; lâmina foliar 4,5-14,5 × 1,6-6 cm, cartácea, levemente discolor, oblanceolada a obovada, ápice agudo a mucronado, margem crenada, base atenuada, face adaxial serícea a glabrescente e face abaxial serícea, ambas com tricomas glandulares sésseis. Capitulescência corimbiforme. Capítulos terminais, sésseis, subentendidos por 3 brácteas foliáceas, ca. $1 \times 1 \mathrm{~cm}$, cordiforme, ápice apiculado, margem denteada, serícea com tricomas glandulares sésseis. Invólucro 6-8,1 × 1,3-1,8 mm, bisseriado, cilíndrico; brácteas involucrais 8,4 brácteas externas e 4 brácteas internas, externas $4-5 \times 0,9-1,3 \mathrm{~mm}$, internas $6,5-7,2 \times 1,7-1,9 \mathrm{~mm}$, lanceoladas, ápice aristado, margem inteira, esverdeadas, pubescentes a glabrescentes. Receptáculo plano, glabro. Flores 4, corola 3,3-3,8 mm compr., lilás a alva, glabra, tubo ca. 1,2 mm compr., limbo ca. $1,2 \mathrm{~mm}$ compr., lacínias $0,8-1 \mathrm{~mm}$ compr. Antera ca. 1,4 mm compr., apêndice do conectivo ca. 0,2 mm compr., agudo a mucronado, base calcarada. Estilete 2-3-3,2 mm compr., ramos do estilete $0,8 \mathrm{~mm}$ compr., ápice obtuso. Cipsela 1,8-2,6 $\mathrm{mm}$ compr., cilíndrica, serícea, 10-costada; carpopódio simétrico, anuliforme, decorrente. Pápus 4-4,4 mm compr., unisseriado, cerdoso e dilatado na base, alvo.

Material examinado: Rio Ventura, $11^{\circ} 40^{\prime} 54^{\prime \prime}$,

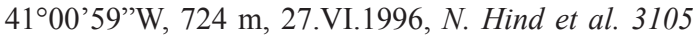
(ALCB, CEPEC, HRB, HUEFS).

Elephantopus mollis caracteriza-se pelos capítulos envolvidos por três brácteas foliáceas, flores de corola alva e pápus unisseriado, cerdoso e dilatado na base, com cinco longas cerdas (Baker 1873). É uma espécie amplamente distribuída no Brasil em todos os domínios fitogeográficos (BFG 2018). Em Morro do Chapéu foi coletada em área de campo rupestre. 


\section{Eremanthus Less.}

O gênero apresenta lâmina foliar argêntea com indumento tomentoso na face abaxial, capitulescência em glomérulos ou em sincefalia, 1-4 flores por capítulo e pápus setoso a paleáceo, com 2-5 séries, persistente ou decíduo (Hind 2000a; Loeuille et al. 2012a). Eremanthus possui 24 espécies sendo a maioria delas endêmica do Cerrado do Platô Central do Brasil (BFG 2018). Na Bahia são registradas oito espécies e em Morro do Chapéu duas.

\section{Chave de identificação das espécies de Eremanthus no Morro do Chapéu, Bahia, Brasil}

1. Sincefálo com $2-5$ capítulos; $2-4$ flores por capítulo 7.1. Eremanthus capitatus

1'. Sincéfalo com 75-105 capítulos; 1 flor por capítulo......... 7.2. Eremanthus glomerulatus

7.1. Eremanthus capitatus (Spreng.) MacLeish, Ann. Missouri Bot. Gard. 74(2): 285. 1987.

Fig. $2 \mathrm{~h}$

Arbusto a árvore 2,5-5 m alt. Ramos cilíndricos, estriados com cicatrizes foliares, incanos a puberulentos. Folhas alternas, pecioladas, pecíolo 1-10 mm compr.; lâmina foliar 3-6 $\times$ 1-4 cm, cartácea, discolor, elíptica, ápice obtuso a agudo, margem inteira a levemente revoluta, base atenuada, face adaxial glabra a puberulenta com tricomas glandulares sésseis, face abaxial incano-tomentosa. Capitulescência em sincefalia, terminal. Capítulos $2-5$ por sincéfalo, sésseis a pedunculados, pedúnculo $2-5 \mathrm{~mm}$ compr. Invólucro 5,5-6 × 1,8-2 mm, cilíndrico, brácteas involucrais 19-22, 4-5 séries, imbricadas, externas 2,6-3,5 × 1,2 mm, ovadas, internas 4,3-5 0,7-1 $\mathrm{mm}$, oblanceoladas, ápice agudo, margem inteira, esverdeadas com ápice vináceo a castanho, puberulento com tricomas glandulares sésseis. Receptáculo plano, alveolado. Flores $2-4$, corola 4,5-4,8 mm compr., lilás com tubo alvo, tubo ca. 1,8 mm compr., lacínias ca. $3 \mathrm{~mm}$ compr. Antera 3-3,4 mm compr., apêndice do conectivo $0,5-0,7$ $\mathrm{mm}$ compr., acuminado, base calcarada. Estilete 6-7 mm compr., pilosa, ramos do estilete $1,5 \mathrm{~mm}$ compr., ápice agudo, lilás. Cipsela 1,2-1,7 mm compr., obcônica, glabra, 10-costada; carpopódio anuliforme. Pápus 4-5,5 mm compr., 3-4 séries, cerdoso-barbelado, sub-iguais, caduco, lilás a alvo. Material selecionado: Fazenda Areia Branca, 11 33 '27'’S, $41^{\circ} 10^{\prime} 40^{\prime \prime} \mathrm{W}, 1.059$ m, 17.IX.2015, M.G. Staudt et al. 112 (ALCB, HUEFS).

Eremanthus capitatus diferencia-se das demais espécies do gênero por possuir 2-5 capítulos em cada sincéfalo, 2-4 flores por capítulo e pápus 3-4 seriado, frequentemente espiralado, alvo a púrpuro (MacLeish 1987; Loeuille et al. 2012a). A espécie é endêmica da Cadeia do Espinhaço e ocorre comumente nos campos rupestres, podendo ser encontrada em áreas de transição de campo rupestre com a floresta secundária, Cerrado ou Caatinga (MacLeisch 1987). Em Morro do Chapéu é amplamente distribuída em bordas de floresta estacional semidecidual e áreas de transição de cerrado e campo rupestre.

7.2. Eremanthus glomerulatus Less., Linnaea 4: 317. 1829.

Fig. 3a

Árvore 2-3 m alt. Ramos cilindricos com cicatrizes foliares, tomentosos. Folhas alternas, sésseis a pecioladas, pecíolo $0,5-0,9 \mathrm{~mm}$ compr.; lâmina foliar 5,5-9 × 2-3 cm, cartácea, discolor, elíptica a ovada, conduplicata, ápice obtuso a agudo, margem crenulada, base cuneada a decorrente, face adaxial pubescente a tomentosa, abaxial lanoso-tomentosa. Capitulescência em sincefalia. Capítulos 75-105 capítulos por sincéfalo. Invólucro ca. $4 \mathrm{~mm}$ compr., obcônico, eximbricado; brácteas involucrais 20-25, 3-4-séries, sub-iguais, 2-3 $\times 0,3-0,5 \mathrm{~mm}$, lanceoladas, ápice agudo, margem inteira, esverdeadas com ápice vináceo, papilosas. Receptáculo plano, alveolado. Flores 1 , corola ca. $5 \mathrm{~mm}$ compr., lilás a alva, tubo ca. 2 mm compr., lacínias ca. $3 \mathrm{~mm}$ compr., papilosa. Antera ca. 2,6 mm compr., apêndice do conectivo ca. 0,6 mm compr., agudo, base calcarada. Estilete ca. 5,2 mm compr., ramos do estilete ca. 1,4 mm compr., ápice agudo. Cipsela 1,5-2 mm compr., obcônica, serícea, 10-costada; carpopódio simétrico, anuliforme. Pápus 1-3 mm compr., 3-4 séries, cerdoso-barbelado, róseo a alvo.

Material selecionado: Cidade das Pedras, próximo às Dunas, $11^{\circ} 29^{\prime} 38^{\prime \prime}$ S, 41 ${ }^{\circ} 19^{\prime} 57^{\prime \prime}$ 'W, 934 m, 15.IX.2015, M.G. Staudt et al. 79 (ALCB, HUEFS).

A espécie caracteriza-se pelo hábito arbustivo robusto ou arbóreo, ramos da capitulescência gríseos com vários sincéfalos por ramo e flores lilases a alvas. Eremanthus glomerulatus tem distribuição para os estados de Minas Gerais, Bahia, Goiás, Distrito Federal e São Paulo, em altitudes que variam de 700 a $1.500 \mathrm{~m}$, onde 
formam grandes populações nos cerrados e campos rupestres (MacLeisch 1987). Em Morro do Chapéu foi encontrada em vegetação de caatinga sob afloramento rochoso e em campos rupestres.

\section{Lepidaploa (Cass.) Cass.}

Segundo Robinson (1990), Lepidaploa pode ser reconhecido por apresentar capítulos subentendidos por brácteas foliáceas, base do estilete dilatada e glândulas na superfície das cipselas. Lepidaploa possuiu o maior número de espécies dentre os gêneros de Vernonieae (ca. 140) e tem distribuição na América Central e do Sul e no oeste dos Andes (Robinson 1999; Keeley \& Robinson 2009). No Brasil são registradas 51 espécies, sendo 38 endêmicas. Na Bahia ocorrem 24 espécies, e nove são consideradas endêmicas para o estado (BFG 2018). Com seis espécies registradas para Morro do Chapéu, Lepidaploa é o gênero com maior riqueza para a tribo.

\section{Chave de identificação das espécies de Lepidaploa no Morro do Chapéu, Bahia, Brasil}

1. Plantas com ramos angulados; lâmina foliar lanceolada.

2. Lâmina foliar pubérula a pubescente com tricomas glandulares sésseis em ambas as faces

8.2. Lepidaploa bahiana

2'. Lâmina foliar com face adaxial estrigosa com tricomas glandulares sésseis e face abaxial albotomentosa..... 8.4. Lepidaploa cotoneaster

1'. Plantas com ramos cilíndricos; lâmina foliar elíptica, ovada, deltoide ou linear.

3. Folhas sésseis, lâmina foliar linear, concolor..... 8.6. Lepidaploa tombadorensis

3'. Folhas pecioladas, lâmina foliar ovada, deltoide, elíptica, discolor.

4. Lâmina ovada a deltoide, margem denteada; brácteas involucrais 60-70, capítulo com 34-39 flores. 8.1. Lepidaploa aurea

4'. Lâmina foliar elíptica a ovada, margem inteira; brácteas involucrais 21-40, capítulo com 10-21 flores.

5. Lâmina foliar $0,6-2,1 \times 0,5-1,4 \mathrm{~cm}$, base cuneada a atenuada; brácteas involucrais 21-36; cipsela densamente serícea 8.3. Lepidaploa chalybaea

5'. Lâmina foliar 2,6-7,4 × 1,5-3,5 cm, base arredondada; brácteas involucrais 35-40; cipsela tomentosa com tricomas glandulares sésseis 8.5. Lepidaploa lilacina

8.1. Lepidaploa aurea (Mart. ex DC.) H.Rob., Proc. Biol. Soc. Washington 103(2): 482. 1990.

Fig. 3b,c

Arbusto 0,5-1 m alt. Ramos cilíndricos, estriados, densamente tomentosos. Folhas alternas, pecioladas, pecíolo 0,4-0,9 cm compr.; lâmina foliar 1,5-3,2 × 1,8-3 cm, membranácea, discolor, ovada a deltóide, ápice obtuso a arredondado, margem denteada, base truncada, face adaxial tomentosa e face abaxial cinéreo-tomentosa. Capitulescência em cimeira escorpióide. Capítulos axilares, sésseis. Invólucro 6-7 × 7-8 mm, campanulado; brácteas involucrais 60-70, imbricadas, 5-6 séries, externas $2,7-3,8 \times 0,5-0,8 \mathrm{~mm}$, internas 4,3-6 × 1,1-1,5 $\mathrm{mm}$, lanceoladas, ápice agudo, margem ciliada, esverdeadas com ápice vináceo, face adaxial glabra, face abaxial serícea. Receptáculo plano, alveolado. Flores 34-39, corola ca. $7 \mathrm{~mm}$ compr., roxa, papilosa, tubo ca. $2 \mathrm{~mm}$ compr., limbo ca. 2 mm compr., lacínias ca. $3 \mathrm{~mm}$ compr. Antera ca. 3,4 mm compr., apêndice do conectivo ca. $0,4 \mathrm{~mm}$ compr., agudo, base calcarada. Estilete 7,3-8 mm compr., lilás a alvo, ramos do estilete $1-1,2 \mathrm{~mm}$ compr., ápice agudo. Cipsela 1,7-2 mm compr., obcônica, serícea, 10-costada; carpopódio simétrico, anuliforme. Pápus bisseriado, série externa paleáceo, 1,1-1,5 mm compr., série interna cerdosobarbelado, 4-5 mm compr., persistente, alvo.

Material selecionado: Serra Olho d'Água, 11³2’39,6”S, 41'9'26,6”W, 1.019 m, 18.III.2016, M.G. Staudt et al. 146/147 (ALCB, HUEFS).

Lepidaploa aurea assemelha-se a Lepidaploa pseudaurea D.J.N.Hind, espécie até então, coletada apenas para Rio de Contas, Bahia. Segundo Hind (1993), L. aurea pode ser distinguida pela lâmina foliar e brácteas involucrais maiores e invólucro com 5-6 séries de brácteas (vs. 3 séries). A espécie tem registro de ocorrência em áreas de Mata Atlântica e Cerrado, em bordas de matas de galeria, nos campos limpos, campos sujos e campos rupestres (BFG 2018). Em Morro do Chapéu foi coletada em floresta estacional semidecidual, caatinga e campo rupestre. 

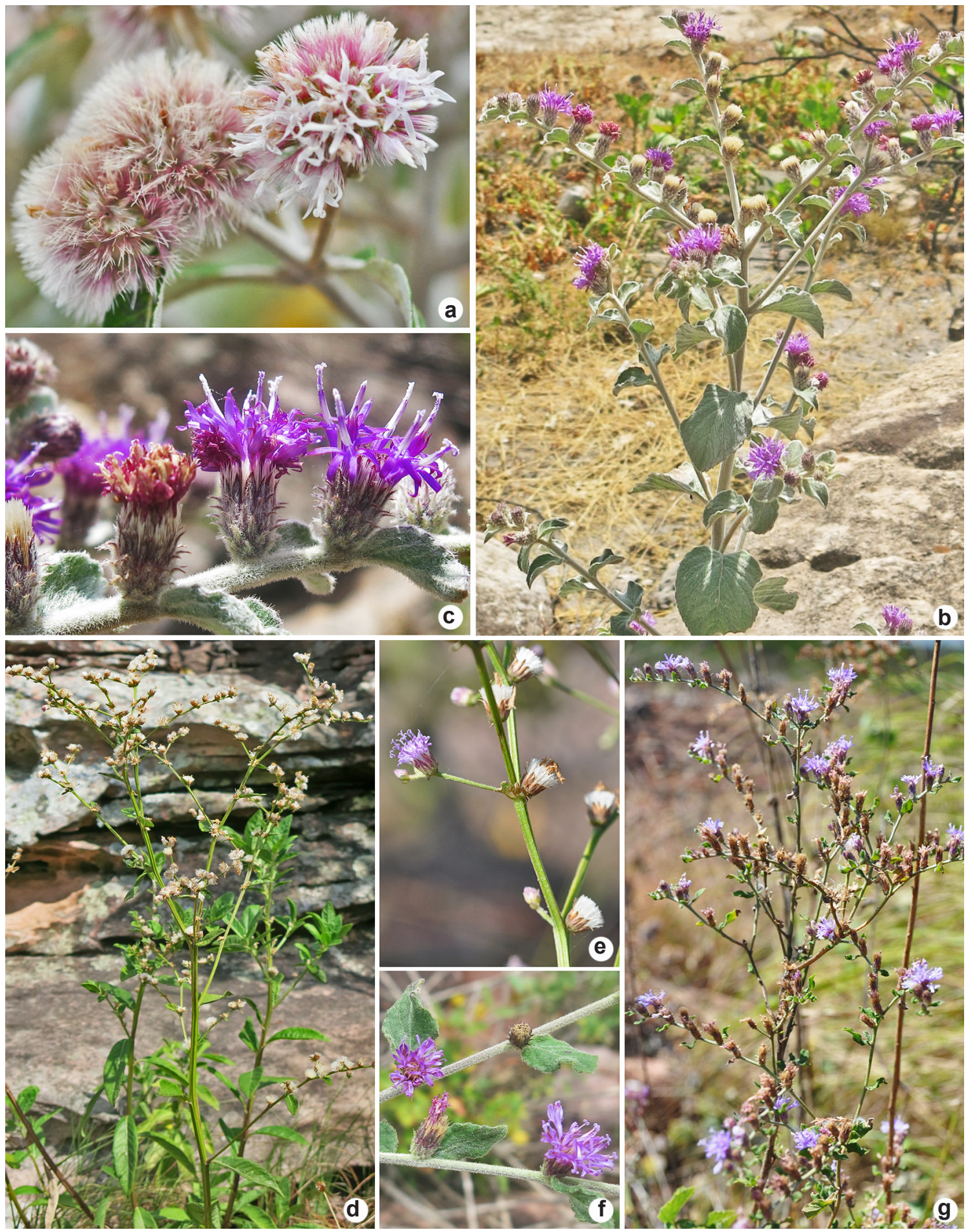

Figura 3 - a. Eremanthus glomerulatus. b, c. Lepidaploa aurea. d, e. Lepidaploa bahiana. f, g. Lepidaploa chalybaea. (a, e, g. L. Barres; b, c, d, f. M. Staudt).

Figure 3 - a. Eremanthus glomerulatus. b, c. Lepidaploa aurea. d, e. Lepidaploa bahiana. f, g. Lepidaploa chalybaea. (a, e, g. L. Barres; b, c, d, f. M. Staudt). 
8.2. Lepidaploa bahiana H.Rob., Phytologia 78(5): 392. 1995.

Fig. 3d,e

Arbusto 0,8-1,2 m alt. Ramos 5-angulados, estriados, pubescentes a glabrescentes com tricomas glandulares sésseis. Folhas alternas, pecioladas, pecíolo $0,5-1 \mathrm{~cm}$ compr.; lâmina foliar 3-11 × 0,8-3,5 cm, coriácea, levemente discolor, lanceolada, ápice acuminado, margem revoluta, base atenuada, pubérulo a pubescente com tricomas glandulares sésseis em ambas as faces. Capitulescência em cimeira escorpióide. Capítulos sésseis. Invólucro 5-6 × 8-10 mm, campanulado; brácteas involucrais $30-35$, imbricadas, 5 séries, externas $2,1-3 \times 0,5-0,7 \mathrm{~mm}$, internas $3,8-5 \times$ 1-1,2 mm, lanceoladas, ápice acuminado, margem ciliada, esverdeadas com ápice vináceo, pubescente com tricomas glandulares sésseis. Receptáculo alveolado. Flores ca. 23, corola 5-6 mm compr., lilás, com tricomas glandulares sésseis, tubo 1-1,5 mm compr., limbo ca. $2 \mathrm{~mm}$ compr., lacínias 2-2,5 $\mathrm{mm}$ compr. Antera ca. 2,5 mm compr.; apêndice do conectivo ca. $0,5 \mathrm{~mm}$ compr., acuminado, base calcarada. Estilete ca. 3,3 mm compr. lilás, ramos do estilete 1,1-2 mm compr., lineares, ápice agudo. Cipsela 0,8-2 mm compr., obcônica, setosa com tricomas glandulares sésseis, 10-costada; carpopódio simétrico, anuliforme. Pápus bisseriado, série externa 0,7-1,3 mm compr., paleácea, série interna 3,2-4 mm compr.; cerdoso-barbelado, persistentes, alvo.

Material selecionado: Cachoeira Ferro Doido, 11'37'38"S, 41 00'03"W, 902 m, 26.XI.2015, M.G. Staudt et al. 121 (ALCB, HUEFS).

Lepidaploa bahiana é reconhecida pelos ramos 5-angulados e pela presença de tricomas glandulares sésseis nos ramos, folhas, brácteas, corola e cipsela (Roque et al. 2016). A espécie é endêmica da Chapada Diamantina e tem ocorrência nos campos rupestres de Morro do Chapéu.

8.3. Lepidaploa chalybaea (Mart. ex DC.) H.Rob., Proc. Biol. Soc.Washington 103(2): 485. 1990.

Fig. 3f,g

Arbusto 0,7-2 m alt. Ramos cilíndricos, estriados, tomentosos a glabrescentes. Folhas alternas, curto-pecioladas, pecíolo até $0,2 \mathrm{~cm}$ compr.; lâmina foliar $0,6-2,1 \times 0,5-1,4 \mathrm{~cm}$, subcoriácea, discolor, elíptica a ovada, ápice obtuso a agudo, margem inteira a sinuosa, base cuneada a atenuada, faces adaxial e abaxial tomentosas com tricomas glandulares sésseis. Capitulescência em cíncino, axilar. Capítulos sésseis. Invólucro 0,6-0,7 $\times 0,3-0,6 \mathrm{~mm}$, cilíndrico a campanulado; brácteas
21-36, imbricadas, 4 séries, externas $2-3 \times 0,5-0,9$ $\mathrm{mm}$, internas $6,5-4 \times 0,7-1,9 \mathrm{~mm}$, lanceoladas, ápice agudo, longo-acuminado a cuspidado, margem inteira, lilases a vináceas, tomentosas. Receptáculo plano, alveolado. Flores 10-21, corola 7-8 mm compr., lilás, pubescente, tubo ca. $1 \mathrm{~mm}$ compr., limbo 2,5-3 mm compr., lacínias 3,5-4 $\mathrm{mm}$ compr. Antera ca. $3 \mathrm{~mm}$ compr., apêndice do conectivo agudo, ca. 0,3 mm compr., base calcarada. Estilete 7-8 mm compr., ramos do estilete $2 \mathrm{~mm}$ compr., ápice agudo, lilás. Cipsela 1-1,5 mm compr., obcônica, densamente serícea, 10-costada; carpopódio anuliforme. Pápus bisseriado, série externa 1,2-1,6 mm compr., paleáceo, persistente, série interna 5,2-6 mm compr., cerdoso-barbelado, caduco, alvo a bege.

Material selecionado: Paxola, estrada para Jacobina, 11³5'32”'S, 41¹2'31'’W, 1.036 m, 19.III.2016, M.G. Staudt et al. 154 (ALCB, HUEFS).

Lepidaploa chalybaea é geralmente confundida com L. cotoneaster (Willd. ex Spreng.) H.Rob. por ambas apresentarem lâmina foliar discolor e capitulescência em cimeira seriada com vários e pequenos capítulos por ramificação. Contudo, esta espécie apresenta folhas menores, venação não evidente e capitulescência com brácteas foliáceas inconspícuas na base dos capítulos (Roque et al. 2016). A espécie é endêmica do Brasil com registro apenas para o nordeste, nos estados da Bahia, Ceará, Pernambuco e Piauí em áreas de Caatinga, campo rupestre e Cerrado (BFG 2018). Em Morro do Chapéu é amplamente distribuída em todas as fitofisionomias, sendo frequentemente encontrada próxima a L. cotoneaster, florescendo e frutificando durante todo o ano.

8.4. Lepidaploa cotoneaster (Willd. ex Spreng.) H.Rob., Proc. Biol. Soc. Washington 103(2): 486. 1990.

Fig. $4 \mathrm{a}$

Arbusto, 0,6-1 m alt. Ramos angulados, estriados, tomentosos. Folhas alternas, curto pecioladas, pecíolo 0,2-0,4 cm compr.; lâmina foliar 2,1-7,4 × 1-2,3 cm, sub-coriácea, discolor, lanceolada, ápice agudo, margem inteira, base cuneada, face adaxial estrigosa com tricomas glandulares sésseis, face abaxial albo-tomentosa. Capitulescência em cíncino foliáceo, axilar. Capítulos sésseis; Invólucro 4,5-5 × 4-6 mm, campanulado; brácteas 30-35, imbricadas, 4-5 séries, vináceas, externas 1,2-2,4 ×0,6-1,2 mm, internas 3,7-4,2 × 1,2-1,5 mm, lanceoladas, ápice acuminado a cuspidado, margem inteira, velutinas. Receptáculo côncavo, alveolado. Flores 19-21, 
corola 4-7 mm compr., lilás, velutina, tubo 1-2 mm compr., limbo 1-1,5 mm compr., lacínias, 2-3 mm compr. Antera 2,2-2,8 mm compr., apêndice do conectivo 0,3-0,8 mm compr., ápice agudo, base calcarada. Estilete 3,7-7,2 mm compr., lilás a alvo, ramos do estilete lineares, 1,1-1,3 mm compr., ápice agudo. Cipsela 0,9-1,5 mm compr., obcônica, serícea, 10-costada; carpopódio simétrico, anuliforme. Pápus bisseriado, série externa paleácea, 0,5-0,8 mm compr., série interna cerdoso-barbelado, 3,8-4,2 mm compr., persistente, alvo.

Material selecionado: Paxola, estrada para Jacobina, 11³5'32”S, 41¹2'31'”, 1.036 m, 19.III.2016, M.G. Staudt et al. 156 (ALCB, HUEFS).

A espécie diferencia-se de L. chalybaea pelos ramos angulados e capítulos arranjados em cimeiras foliáceas. Lepidaploa cotoneaster tem registro para os estados da Bahia, Minas Gerais e São Paulo em áreas de Cerrado e campo rupestre (BFG 2018). Em Morro do Chapéu habita diferentes fitofisionomias.

8.5. Lepidaploa lilacina (Mart. ex DC.) H.Rob., Proc. Biol. Soc. Washington 103(2): 489. 1990.

Fig. $4 b$

Arbusto 0,3-0,8 m alt. Ramos cilíndricos, estriados, tomentosos. Folhas alternas, pecioladas, pecíolo 0,3-0,9 cm compr.; lâmina foliar 2,6-7,4 × 1,5-3,5 cm, sub-coriácea, discolor, elíptica, ápice agudo a obtuso, margem inteira, base arredondada, face adaxial setosa e face abaxial gríseo-tomentosa, com tricomas glandulares sésseis em ambas as faces. Capitulescência em cíncino, axilar. Capítulos sésseis. Invólucro 6-7 × 5-7 cm, campanulado; brácteas involucrais 35-40, imbricadas, 4 séries, esverdeadas com ápice vináceo, externas $1,5-2,1 \times 0,6-0,8 \mathrm{~mm}$, 5-6 × 1,2-1,5 mm, lanceoladas, ápice acuminado a cuspidado, margem inteira, tomentosas. Receptáculo plano, fimbriado. Flores 15-16, corola 6-7 mm compr., alva, tomentosa, tubo 3-4 mm compr., limbo 1-1,5 mm compr., lacínias 2-2,2 mm compr. Antera ca. 2,8 mm compr., apêndice do conectivo $0,5-0,7$ mm compr., ápice agudo, base caudada. Estilete ca. 7,5 mm compr., ramos do estilete ca. 1,4 mm compr., ápice agudo. Cipsela 1,3-1,7 mm compr., obcônica, tomentosa com tricomas glandulares sésseis, 10-costada; carpopódio simétrico, anuliforme. Pápus bisseriado, série externa $0,8-1 \mathrm{~mm}$ compr., paleácea, persistente, série interna ca. 4,2 $\mathrm{mm}$ compr., cerdoso-barbelado, caduco.

Material selecionado: Estrada da Veredinha, 11³6'19'S, 4059'16”W, 904 m, 27.XI.2015, M.G. Staudt et al. 122 (ALCB, HUEFS).
A espécie diferencia-se de Lepidaploa cotoneaster pelos ramos (cilíndrico vs. angulosos), formato da lâmina foliar (elíptica vs. lanceolada) e pelo número menor de flores por capítulo (15-16 vs. 19-20). Lepidaploa lilacina é endêmica do Cerrado e dos campos rupestres da Cadeia do Espinhaço (BFG2018) e em Morro do Chapéu ocorre em áreas de caatinga e campo rupestre.

8.6. Lepidaploa tombadorensis (H.Rob.) H.Rob., Proc. Biol. Soc.Washington 103(2): 492. 1990.

Fig. $4 \mathrm{c}, \mathrm{d}$

Subarbusto 40-70 cm alt. Ramos cilíndricos, estriados, glabros. Folhas alternas, sésseis; lâmina foliar 2,5-7,2 × 0,3-0,7 cm, coriácea, concolor, linear, conduplicada, ápice obtuso, margem inteira, base cuneada, serícea em ambas as faces. Capitulescência em cíncino. Capítulos sésseis. Invólucro 7-12 × 7-13 mm, campanulado; brácteas involucrais 35-36, imbricadas, 6 séries, esverdeadas com ápice vináceo, externas obovadas a orbiculares, 1,6-2,9 × 1,1-2 mm, internas oblongas a oblanceoladas, 5,3-6,2 $\times$ 1,4-2,2 mm, ápice arredondado, margem inteira, esverdeadas, densamente vilosas. Receptáculo plano, alveolado. Flores 24-25, corola 8,3-12 $\mathrm{mm}$ compr., lilás, pilosa, tubo $2-3 \mathrm{~mm}$ compr., limbo 2-3 mm compr., lacínias 3,3-5 mm compr. Antera 3,2-3,7 mm compr., apêndice do conectivo 0,3-0,7 mm compr., ápice agudo, base calcarada. Estilete ca. 1,2 mm compr., ramos do estilete ca. $4 \mathrm{~mm}$ compr., lineares, ápice agudo. Cipsela 2-2,5 mm compr., obcônica, serícea com tricomas glandulares sésseis, 10-costada; carpopódio simétrico, anuliforme. Pápus bisseriado, série externa paleácea, 1,2-1,8mm compr., série interna cerdoso-barbelado, ca. 7,1 mm compr., ferrugíneo. Material selecionado: Tabuleiro do Tigre, $11^{\circ} 35^{\prime} 59^{\prime}$ 'S, 41 ${ }^{\circ} 09^{\prime} 52^{\prime}$ 'W, 1.102 m, 15.IX.2015, M.G. Staudt et al. 91 (ALCB, HUEFS).

Segundo Robinson (1980), as folhas estreitamente lineares a distinguem das outras espécies do grupo, além das curtas brácteas involucrais com ápice arredondado que também são distintivas. Lepidaploa tombadorensis é endêmica da Chapada Diamantina e tem Morro do Chapéu como localidade-tipo. $\mathrm{Na}$ área de estudo foi encontrada em áreas de caatinga e campo rupestre.

\section{Lessingianthus H.Rob.}

Lessingianthus distingue-se de Lepidaploa pelos capítulos que são geralmente maiores, base do estilete cilíndrica (vs. dilatada), receptáculo não 

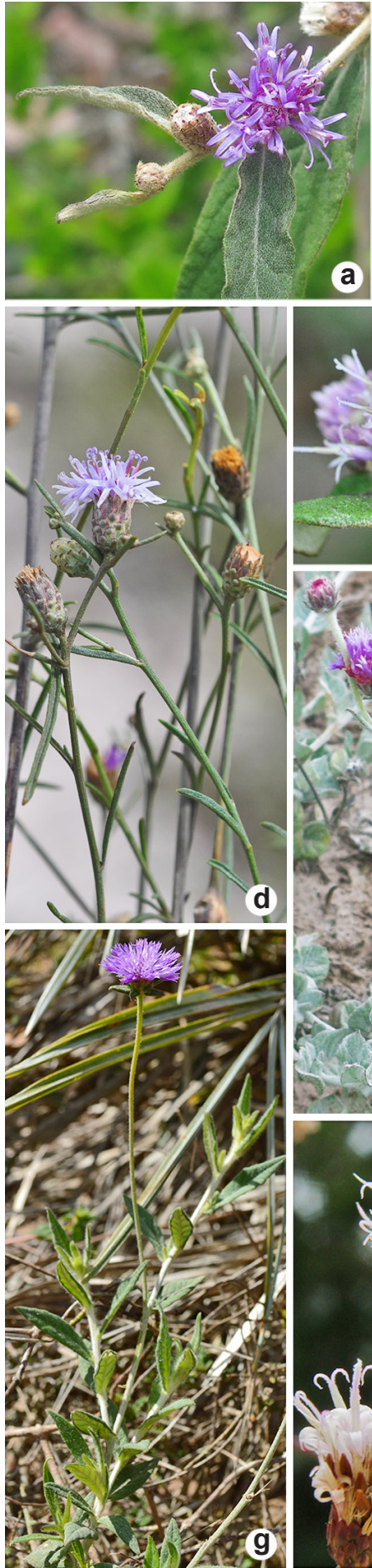
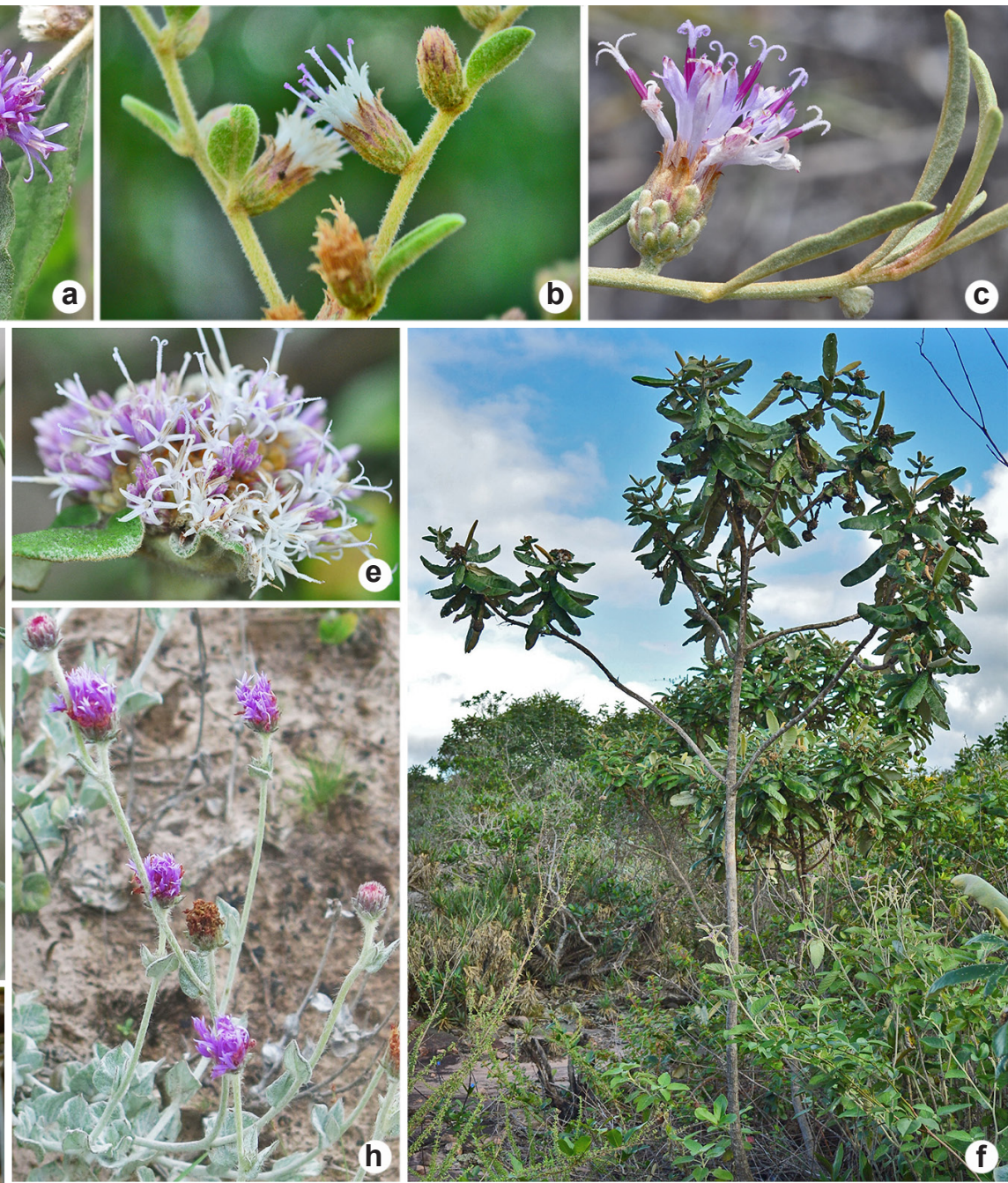
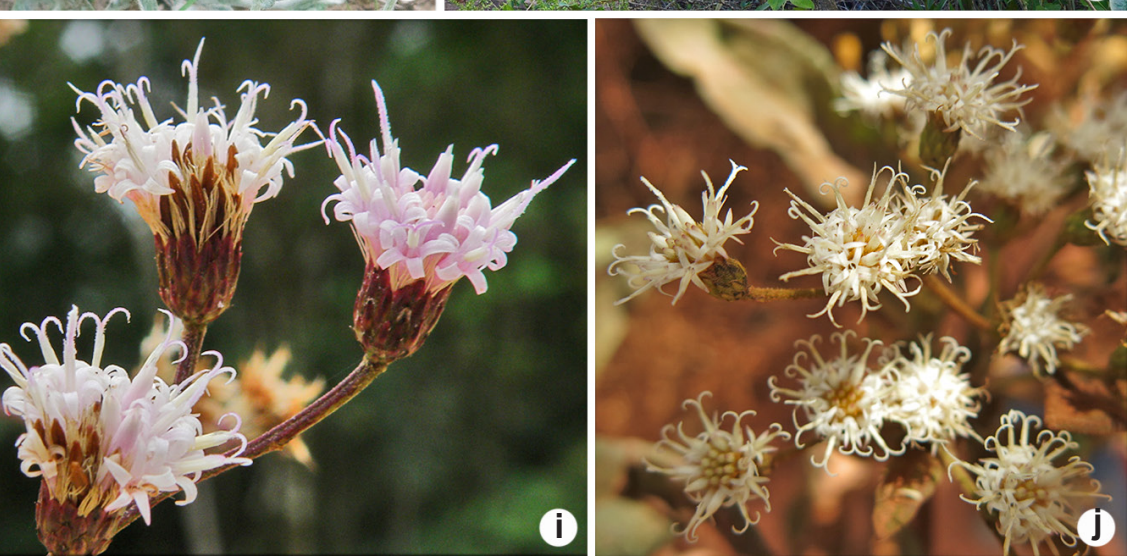

Figura 4 - a. Lepidaploa cotoneaster. b. Lepidaploa lilacina. c, d. Lepidaploa tombadorensis. e, f. Paralychnophora reflexoauriculata. g. Stilpnopappus semirianus. h. Stilpnopappus sp. nov. i. Vernonanthura brasiliana. j. Vernonanthura polyanthes. (a. M. Staudt; b, f, g. A. Gandara; c, d, e. L. Barres; i. H. Ogasawara; j. L. Moura).

Figure 4 - a. Lepidaploa cotoneaster. b. Lepidaploa lilacina. c, d. Lepidaploa tombadorensis. e, f. Paralychnophora reflexoauriculata. g. Stilpnopappus semirianus. h. Stilpnopappus sp. nov. i. Vernonanthura brasiliana. j. Vernonanthura polyanthes. (a. M. Staudt; b, f, g. A. Gandara; c, d, e. L. Barres; i. H. Ogasawara; j. L. Moura). 
alveolado ( $v s$. alveolado) e ausência de glândulas na superfície da cipsela (Robinson 1988, 1990). Lessingianthus é exclusivamente sul-americano e distribuído principalmente no Brasil, Argentina, Bolívia, Colômbia, Paraguai, Uruguai e Venezuela (Keeley \& Robinson 2009). O gênero apresenta 114 espécies no Brasil, sendo que 85 delas são endêmicas (BFG 2018). Em Morro do Chapéu há ocorrência de apenas uma espécie para o gênero.

9.1. Lessingianthus morii (H.Rob.) H.Rob., Proc. Biol. Soc. Washington 101(4): 945. 1988.

Arbusto $60 \mathrm{~cm}$ alt. Ramos cilíndricos, estriados, pubescentes. Folhas alternas, pecioladas, pecíolo ca. $0,5 \mathrm{~cm}$ compr.; lâmina foliar 5-11 × 2,2-5,9 cm, coriácea, levemente discolor, ovada, ápice caudado, margem ondulada, base atenuada, face adaxial com indumento estriguloso, face abaxial tomentosa com tricomas glandulares sésseis e indumento seríceo nas nervuras. Capitulescência em cimeira escorpióide. Capítulos sésseis. Invólucro 7-8 × 6-7 mm, campanulado; brácteas involucrais 57-62, imbricadas, 7 séries, externas ovadas $2-3 \times 1,2-2$ $\mathrm{mm}$, internas lanceoladas 5,5-7 × 1,7-2,5 mm, ápice agudo a obtuso, margem inteira, castanha, seríceas. Receptáculo plano. Flores ca. 31, corola 10-11 mm compr., glabra, lilás, tubo ca. $2 \mathrm{~mm}$ compr., limbo ca. $5 \mathrm{~mm}$ compr., lacínias ca. 4 $\mathrm{mm}$ compr. Antera 3,6-4,2 mm compr., apêndice do conectivo ca. 0,3 $\mathrm{mm}$ compr., agudo, base calcarada. Estilete 11-13 mm compr., ramos do estilete lineares, 2,3-3,1 mm compr., ápice agudo, pilosos. Cipsela 2-2,2 mm compr., cilíndrica, pubescente, 10-costada; carpopódio simétrico, anuliforme. Pápus bisseriado, séria externa paleácea, ca. 1,5-1,8 mm compr., série interna cerdosa-barbelado, ca. $7 \mathrm{~mm}$ compr., persistente, amarelado.

Material examinado: $19 \mathrm{~km}$ da cidade na BA-052, sentido Mundo Novo, $11^{\circ} 38^{\prime} \mathrm{S}, 41^{\circ} 02^{\prime} \mathrm{W}, 900 \mathrm{~m}$, 2.III.1977, R.M. Harley et al. 19242 (RB).

Segundo Robinson (1979), L. morii é morfologicamente similar a Lessingianthus ammophilus (Gardner) H.Rob. e diferenciase pelo ápice das folhas caudado ( $v s$. obtuso a arredondado), lâmina foliar tomentosa com tricomas glandulares sésseis (vs. glabra) e corola lilás (vs. magenta). Lessingianthus morii é endêmica do Brasil e tem ocorrência restrita para o nordeste (Bahia, Ceará e Pernambuco) (BFG 2018). Com apenas um registro para Morro do Chapéu, a espécie foi encontrada em área de campo rupestre.

\section{Paralychnophora MacLeish}

O gênero pode ser reconhecido através da capitulescência em sincéfalos pedunculados, solitários e axilares que se tornam pendentes quando maduros (MacLeish 1984; Hind 2000b). Paralychnophora é endêmico do Brasil com seis espécies que ocorrem nos estados de Alagoas, Pernambuco, Bahia, Sergipe e Minas Gerais, em áreas de Caatinga, Cerrado e Mata Atlântica (BFG 2018). Em Morro do Chapéu são registradas duas espécies.

\section{Chave de identificação das espécies de Paralychnophora no Morro do Chapéu, Bahia, Brasil}

1. Folhas pecioladas (pecíolo $2-3,5 \mathrm{~cm}$ compr.), lâmina foliar plana, base cuneada

1'. Folhas sésseis, lâmina foliar fortemente revoluta, base auriculada 10.1. Paralychnophora harleyi 10.2. Paralychnophora reflexoauriculata

10.1. Paralychnophora harleyi (H.Rob.) D.J.N.Hind, Kew Bull. 55(2): 370. 2000.

Arvoreta 1,5-3,5 m alt. Ramos cilíndricos, densamente lanuginosos, tornando-se lanosos no ápice. Folhas alternas, pecioladas, pecíolo 2-3,5 cm compr.; lâmina foliar 4-14 × 2-7 cm, coriácea, discolor, elíptica, ápice obtuso a retuso, margem inteira, base cuneada, face adaxial lanuginosa, glabrescente, face abaxial densamente cinéreo-lanuginosa. Capitulescência em sincéfalos pedunculados, solitários e axilares, pendentes na maturidade. Capítulos sésseis. Invólucro $0,4 \times$ $0,3 \mathrm{~mm}$, cilíndrico; brácteas involucrais $23-25$, imbricadas, 6 séries, sub-iguais, ca. $6 \times 1 \mathrm{~mm}$, lanceoladas, ápice acuminado, margem inteira, esverdeadas com ápice castanho, face abaxial glabra, face abaxial vilosas e com um tufo de vilosidade no ápice. Receptáculo plano. Flores 6-8, corola ca. $9 \mathrm{~mm}$ compr., rósea a alva, tubo ca. $4 \mathrm{~mm}$ compr., limbo ca. $1 \mathrm{~mm}$ compr., lacínias, ca. $4 \mathrm{~mm}$ compr., papilosas. Antera ca. $3 \mathrm{~mm}$ compr., apêndice do conectivo agudo, ca. 0,7 
mm compr., base calcarada. Estilete ca. $10 \mathrm{~mm}$ compr., alvo, ramos do estilete ca. $2 \mathrm{~mm}$ compr., ápice agudo. Cipsela 3-4 mm compr., prismática, glabra, 10-costada; carpopódio inconspícuo. Pápus bisseriado, série externa paleácea, ca. $2 \mathrm{~mm}$ compr., série interna ca. $4 \mathrm{~mm}$ compr., cerdoso-barbelado, caduco, ferrugíneos.

Material selecionado: Fazenda Guariba, nascente do rio

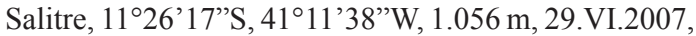
E. Melo et al. 4803 (ALCB, HUEFS).

Esta espécie é muito próxima e facilmente confundida com Paralychnophora bicolor (DC.) MacLeish. Segundo Loeuille (2012b), ambas ocorrem na Bahia e $P$. harleyi diferencia-se por apresentar 5-12 flores por capítulo (vs. 2-3 em $P$. bicolor). Paralychonophora harleyi é endêmica da Bahia e ocorre nos domínios da Caatinga e do Cerrado (BFG 2018). Em Morro do Chapéu ocorre em área de campo rupestre, juntamente com uma grande população de Paralychnophora reflexoauriculata (G.M.Barroso) MacLeish, que é abundante na região.

\subsection{Paralychnophora reflexoauriculata} (G.M.Barroso) MacLeish, Taxon 33:106. 1984.

Fig. 4e,f

Arvoreta 1,5-3,5 m alt. Ramos cilíndricos, densamente lanuginosos, tornando-se lanosos no ápice. Folhas alternas, sésseis; lâmina foliar 4-15 × 2-5 cm, revoluta, coriácea, discolor, elíptica a obovada, ápice obtuso a retuso, margem fortemente revoluta, base auriculada, face adaxial lanuginosa quando as folhas são jovens e glabras nas folhas maduras, face abaxial densamente cinéreo-lanuginosa. Capitulescência em sincéfalos pedunculados, solitários e axilares, pendentes na maturidade. Capítulos sésseis. Invólucro $0,4 \times$ 0,3 mm, cilíndrico; brácteas involucrais 23-25, 6 séries, imbricadas, sub-iguais, 6-7 × 1-1,5 mm, lanceoladas, ápice acuminado a cuspidado, margem inteira, pubescente no ápice da face abaxial. Receptáculo plano. Flores ca. 15, corola ca. 9-10 $\mathrm{mm}$ compr., rósea a alva, tubo ca. $5 \mathrm{~mm}$ compr., lacínias ca. $4 \mathrm{~mm}$ compr., pubescente no ápice. Antera ca. $3 \mathrm{~mm}$ compr., apêndice do conectivo agudo, ca. 0,8 $\mathrm{mm}$ compr., base calcarada. Estilete 6-11 mm compr., alvo, ramos do estilete 2-3 mm compr., ápice agudo. Cipsela 3-4,5 mm compr., cilíndrica a prismática, glabra, 10-costada; carpopódio inconspícuo. Pápus bisseriado, série externa 1,5-2 mm compr., paleáceo, persistente, série interna ca. $6 \mathrm{~mm}$ compr., cerdoso-barbelado, caduco, ferrugíneos.
Material selecionado: Cachoeira Ferro Doido, 11'37'38'S, 41 00'03'W, 902 m, 18.VI.2015, M.G. Staudt et al. 71 (ALCB, HUEFS).

Paralychnophora reflexoauriculata diferencia-se de $P$. harleyi por apresentar folhas sésseis (vs. pecioladas), lâmina foliar revoluta (vs. plana) e base auriculada (vs. cuneada). A espécie tem registro apenas para o Nordeste (BFG 2018) e possui ampla distribuição nas diferentes fitofisionomias de Morro do Chapéu.

\section{Piptocarpha R.Br.}

O gênero é representado por muitas espécies de hábito arbustivo escandente. Os ramos e as folhas apresentam tricomas estrelados ou lepidotos, a inflorescência é axilar e as brácteas são decíduas (Smith 1982; Smith \& Coile 2007). Piptocarpha é neotropical com ca. 50 espécies e o maior centro de distribuição se estende do sul do Brasil e norte da Argentina até a América Central (Robinson 2002). São registradas 32 espécies em todos os domínios fitogeográficos do Brasil (BFG 2018) e 12 espécies para a Bahia (Zugaib \& Amorim 2014). Em Morro do Chapéu ocorre apena uma espécie.

11.1. Piptocarpha leprosa (Less.) Baker, Fl. bras. 6(2): 128.1873.

Arbusto escandente ca. $3 \mathrm{~m}$ alt. Ramos quadrangulares, estriados, lepidoto-tomentosos. Folhas alternas, pecioladas, pecíolo $0,5-1 \mathrm{~cm}$ compr.; lâmina foliar 3-10 × 1-3 cm, cartácea, discolor, elíptica, ápice acuminado, margem inteira, base cuneada, face adaxial glabra, face abaxial densamente lepidota com glândulas translúcidas. Capitulescência corimbiforme. Capítulos axilares, sub-sésseis. Invólucro 4-5 × 1,8-2,5 mm, cilíndrico; brácteas ca. 20, 5 séries, imbricadas, decíduas, externas ovadas, 1,7 × 1,2 $\mathrm{mm}$, internas oblongas a oblanceoladas, $3 \times 1,5$ $\mathrm{mm}$, ápice agudo, margem inteira, esverdeadas com ápice castanho, tomentosas. Receptáculo cônico. Flores 3, corola 5,2-7 mm compr., tricomas glandulares sésseis, creme, tubo 2-2,5 mm compr., limbo 1,5-1,7 mm compr., lacínias 1,5-3 mm compr., papilosas. Antera 2,5-3 $\mathrm{mm}$ compr., apêndice do conectivo ca. $0,3 \mathrm{~mm}$ compr., agudo a obtuso, base calcarada. Estilete ca. 8,5 mm compr., alvo, ramos do estilete ca. 1,4 mm compr., ápice agudo. Cipsela ca. 2,2 mm compr., cilíndrica, glabra, 10-costada; carpopódio, simétrico, anuliforme. Pápus bisseriado, desigual, série externa paleáceo, ca. 2,5 mm compr., série interna cerdosa, $5 \mathrm{~mm}$ compr., creme. 
Material examinado: Fazenda Guariba, $11^{\circ} 26^{\prime} 21^{\prime \prime S}$, 4111'35”W, 1.067 m, 28.IV.2011, E. Melo et al. 9692 (HUEFS).

Piptocarpha leprosa se assemelha a Piptocarpha oblonga (Gardner) Baker, mas é facilmente diferenciada pelos ramos quadrangulares e capítulos pedunculados a subsésseis ( $v s$. ramos cilíndricos e capítulos sésseis). Também é muito próxima de Piptocarpha quadrangularis (Vell.) Baker, da qual diferencia-se por possuir folhas cartáceas ( $v s$. coriáceas) e tricomas lepidotos (vs. tricomas estrelados na face abaxial da folha) (Grokoviski 2007). A espécie está distribuída nos estados do sudeste, sul (Paraná), nordeste (Bahia,
Ceará) e centro-oeste (Mato Grosso) (BFG 2018). Em Morro do Chapéu foi encontrada em área de floresta estacional semidecidual.

\section{Stilpnopappus Mart. ex DC.}

O gênero é caracterizado pelo pápus paleáceo, bisseriado, com a série externa mais curta, receptáculo alveolado e cipsela com indumento viloso (Esteves 1993). Stilpnopappus compreende 20 espécies (Robinson 1999; Funk et al. 2009), sendo nove restritas ao Brasil, principalmente em áreas de caatinga, restinga e campo rupestre $(\mathrm{BFG}$ 2018). Na área de estudo foram encontradas quatro espécies.

\section{Chave de identificação das espécies de Stilpnopappus no Morro do Chapéu, Bahia, Brasil}

1. Lâmina foliar ovada a orbicular, margem denteada 12.4. Stilpnopappus sp. nov.

1'. Lâmina foliar elíptica, lanceolada, estreito-lanceolada, linear; margem inteira.

2. Ramos decumbentes, lâmina foliar com base atenuada 12.1. Stilpnopappus semirianus

2'. Ramos eretos, lâmina foliar com base cuneada ou semi-amplexicaule.

3. Lâmina foliar plana, ápice acuminado, base cuneada .......12.2. Stilpnopappus suffruticosus

3'. Lâmina foliar conduplicada, ápice agudo, base semi-amplexicaule.... 12.3. Stilpnopappus tomentosus

12.1. Stilpnopappus semirianus R.Esteves, Bradea 6(13):118. 1993.

Fig. $4 \mathrm{~g}$

Erva prostrada, 30-60 $\mathrm{cm}$ alt. Ramos cilíndricos, estriados, vilosos. Folhas alternas, congestas na base, sésseis; lâmina foliar 2,8-5 × 0,4-0,8 cm, cartácea, discolor, lanceolada, ápice agudo, margem inteira a revoluta, base atenuada, face adaxial serícea, face abaxial gríseo-tomentosa, serícea nas nervuras. Capítulos solitários no ápice dos ramos ou capítulos $2-3$ reunidos, constituindo uma cima laxa. Invólucro $0,7-1,1 \times 0,7-1 \mathrm{~cm}$, campanulado; brácteas ca. 25, 3 séries, imbricadas, verdes com margem e ápice vináceo, externas $5,3 \times 2 \mathrm{~mm}$, internas $6,5-7,2 \times 1,7-2 \mathrm{~mm}$, lanceoladas, ápice apiculado, margem inteira, serícea. Receptáculo alveolado com aristas longas. Flores ca. 52, corola 5-7,5 mm compr., purpúrea, tricomas glandulares sésseis, tubo 1-3 mm compr., limbo 1-2 mm compr., lacínias 2,5-3 mm compr. Antera ca. $3 \mathrm{~mm}$ compr., apêndice do conectivo acuminado, ca. 0,6 mm compr., base calcarada a arredondada. Estilete 4,2-6,8 $\mathrm{mm}$ compr., ramos do estilete lineares, ca. 1,4 mm compr., ápice agudo, púrpuro. Cipsela ca. $1 \mathrm{~mm}$ compr., obcônica, densamente velutina com tricomas glandulares sésseis, 10-costada; carpopódio inconspícuo. Pápus bisseriado, paleáceo, série externa 1,5-2,1 mm compr., série interna 4-5,3 mm compr., persistentes, púrpuro a alvo, podendo ser ferrúgineo.

Material selecionado: Morrão, $11^{\circ} 35^{\prime} 27,7$ 'S, $41^{\circ} 12^{\prime} 30,5^{\prime} \mathrm{W}, 1.265 \mathrm{~m}, 18 . \mathrm{VI} .2015$, M.G. Staudt et al. 62 (ALCB, HUEFS).

Segundo Esteves (1993), S. semirianus é simpátrica a Stilpnopappus tomentosus, sendo ambas distintas entre si pelo hábito (erva prostrada vs. erva ereta) e lâmina foliar (lanceolada vs. linear e plana vs. conduplicada), respectivamente. A espécie é endêmica dos campos rupestres da Chapada Diamantina e tem Morro do Chapéu como localidade-tipo. $\mathrm{Na}$ área de estudo foi coletada em áreas de transição de cerrado e campo rupestre.

12.2. Stilpnopappus suffruticosus Gardner, London J. B.5: 228. 1846.

Erva, 20-30 cm alt. Ramos cilíndricos, estriados, seríceos. Folhas alternas, rosuladas, sésseis; lâmina foliar 3-8 ×0,1-0,6 cm, coriácea, discolor, lanceolada a estreito-lanceolada, ápice acuminado, margem inteira, base cuneada, face adaxial estrigosa com tricomas glandulares sésseis, face abaxial densamente serícea. Capítulos sésseis. Invólucro 5-8 × 8-11 mm, campanulado; 2 séries 
de brácteas foliáceas com 10 brácteas cada, brácteas involucrais 19-24, 3 séries, imbricadas, externas foliáceas, esverdeadas, internas 5-7 × 1-1,8 mm, lanceoladas, ápice acuminado, margem inteira, esverdeadas com ápice vináceo, face abaxial serícea com tricomas glandulares sésseis. Receptáculo plano, fimbriado. Flores 59-62, corola 3,8-9 mm compr., roxa, tricomas glandulares sésseis, tubo 1-3 mm compr., limbo 1-2,5 mm compr., lacínias ca. 3,5 mm compr. Antera 2,5-3 mm compr., apêndice do conectivo ca. 0,4 mm compr., agudo, base calcarada. Estilete 6-7 $\mathrm{mm}$ compr., roxo a alvo, ramos do estilete ca. 1,4 mm compr., ápice agudo. Cipsela 1-2 mm compr., obcônica, serícea, 10-costada; carpopódio anuliforme, simétrico. Pápus bisseriado, paleáceo, desigual, série externa ca. 8 páleas, 1,3-1,7 mm compr., série interna ca. 11 páleas, 3,5-4,5 mm compr., púrpuro.

Material selecionado: Serra do Olho d'Água, 11'32'39,6”S, 41 9'26,6”W, 1.019 m, 18.III.2016, M.G. Staudt et al. 145 (ALCB, HUEFS).

A espécie apresenta lâmina foliar semelhante a de Stilpnopappus tomentosus, entretanto, $S$. suffruticosus diferencia-se pela presença de três séries de brácteas ( $v s .5$ séries) e maior número de flores por capítulo (59-62 vs. 35-49). Na área de estudo, foi coletada em campo rupestre e é considerada um novo registro para o estado da Bahia.

12.3. Stilpnopappus tomentosus Mart. ex DC., Prodr. 5: 76.1836.

Erva, 15-30 cm alt. Ramos cilíndricos, estriados, tomentosos. Folhas alternas, rosuladas, sésseis; lâmina foliar 3-6,5×0,1-0,4 cm, coriácea, discolor, linear a linerar-lanceolada, conduplicada, ápice acuminado, margem inteira, base atenueada, face adaxial serícea com tricomas glandulares sésseis, face abaxial lanosa. Capítulos sésseis. Invólucro 6-8 × 6-10 mm, campanulado; 5 brácteas foliáceas, brácteas involucrais 21-33, 5 séries, imbricadas, externas 4-5 × 1,7-2 mm, ovadas a lanceoladas, internas 5-7 × 1-1,8 mm, estreito-lanceoladas, ápice acuminado, margem inteira, esverdeadas com ápice vináceo, face abaxial serícea com tricomas glandulares sésseis. Receptáculo plano, alveolado, aristado. Flores 35-49, corola 7-9,5 mm compr., roxa, com tricomas glandulares sésseis, tubo 3-4 mm compr., limbo 1-2 mm compr., lacínias 3-3,5 mm compr. Antera 2,2-3 mm compr., apêndice do conectivo ca. 0,3 mm compr., agudo, base calcarada. Estilete 3,2-7 mm compr., alvo, ramos do estilete
1-1,4 mm compr., ápice agudo, roxo, piloso. Cipsela ca. $1 \mathrm{~mm}$ compr., obcônica, velutina, 10-costada; carpopódio anuliforme, simétrico. Pápus bisseriado, paleáceo, desigual, série externa com 7-10 páleas, 1,3-2 mm compr., série interna 8-12 páleas, 3,8-5 mm compr., persistentes, róseo a alvo, tornando-se ferrugíneo.

Material selecionado: Paxola, estrada para Jacobina, 11'35'32,9'S, 4112'31,1'W, 1.036 m, 19.III.2016, M.G. Staudt et al. 155 (ALCB, HUEFS).

Stilpnopappus tomentosus diferencia-se das demais espécies por apresentar lâmina foliar estreito-linear e face abaxial lanosa. A espécie é endêmica da Bahia com muitos registros nos campos rupestres da Chapada Diamantina e na Caatinga ao norte do estado. No local de estudo também foi coletada em áreas de caatinga e campo rupestre.

12.4. Stilpnopappus sp. nov.

Fig. 4h

Erva decumbente $20-40 \mathrm{~cm}$ alt. Ramos cilíncricos, estriados, densamente albo-seríceo. Folhas, alternas, sésseis; lâmina foliar 1,2-2 × 0,7-1,9 cm, cartácea, discolor, ovada a orbicular, ápice agudo a acuminado, margem denteada, revoluta, base atenuada, faces adaxial e abaxial albotomentosa com indumento seríceo nas nervuras e tricomas glandulares sésseis. Capítulos solitários no ápice dos ramos ou capítulos reunidos em dois, constituindo uma cima laxa. Invólucro $0,5-1 \times$ 0,7-1,3 cm, campanulado; brácteas involucrais ca. 32, 4-5 séries, imbricadas, foliáceas, externas $6 \times 1,8 \mathrm{~mm}$ compr., lanceoladas, internas $7 \times 1,2$ mm compr., estreito-lanceoladas, ápice cuspidado, margem ciliada, esverdeadas com margem e ápice vináceo, seríceas. Receptáculo convexo, alveolado com aristas longas. Flores 42-45, corola 5-8 mm compr., púrpura, tubo ca. $1 \mathrm{~mm}$ compr., limbo ca. 0,5-1 mm compr., lacínias 2,5-3 mm compr., papilosas. Antera 3-3,3 mm compr., apêndice do conectivo agudo a acuminado, ca. 0,3 mm compr., base calcarada. Estilete 5-7 mm compr., ramos do estilete lineares, 1,5-2 mm compr., ápice agudo, lilás. Cipsela 1,2-1,7 mm compr., obcônica, densamente serícea com tricomas glandulares sésseis, 10-costada; carpopódio anuliforme. Pápus bisseriado, paleáceo, série externa ca. 1,7 mm compr., série interna 4,5-5 mm compr., persistentes, alvo com a base da pálea vinácea.

Material selecionado: Tabuleiro do Tigre, $11^{\circ} 35^{\prime} 58,8^{\prime}$ 'S, 41 9'51,4'W, 1.095 m, 18.III.2015, M.G. Staudt et al. 134 (ALCB, HUEFS).

Stilpnopappus sp. nov. diferencia-se das demais espécies do gênero pela folha ovada 
a orbicular, margem denteada e nervuras bem marcadas na face adaxial. Os ramos, a lâmina foliar em ambas as faces e as brácteas involucrais são densamente albo-tomentosas. A espécie nova de Stilpnopappus encontra-se restrita a localidade do Tabuleiro do Tigre, área de campo rupestre que abriga outras espécies de Asteraceae endêmicas do município de Morro do Chapéu (Acritopappus santosii, Lapidia apicifolia, Scherya bahiensis, Stylotrichium edmundoi e Trichogonia tombadorensis).

\section{Vernonanthura H.Rob.}

$\mathrm{O}$ gênero apresenta hábito arbustivo ou arbóreo, capitulescência tirsoide a piramidalmente paniculada e corola glabra (Robinson 1999). Vernonanthura possui 70-76 espécies distribuídas em toda a América tropical (Keeley \& Robinson 2009). No Brasil são registradas 40 espécies, sendo que 22 são endêmicas. Na Bahia há registro de sete espécies e destas, quatro são registradas para Morro do Chapéu (Ogasawara \& Roque 2015).

\section{Chave de identificação das espécies de Vernonanthura no Morro do Chapéu, Bahia, Brasil}

1. Capitulescência em racemos corimbiformes; ramos e nervuras foliares vináceos; folhas sésseis; lâmina foliar estreito-elíptica (ca. $0,8 \mathrm{~cm}$ larg.). 13.2. Vernonanthura laxa

1'. Capitulescência paniculiforme; ramos e nervuras sem coloração vinácea; folhas pecioladas; lâmina foliar obovada ou elíptica $(1,2-3,6 \mathrm{~cm}$ larg.).

2. Brácteas involucrais $78-80$; flores ca. 41 13.1. Vernonanthura brasiliana

2'. Brácteas involucrais 22-62; flores 11-27.

3. Brácteas involucrais em 5 séries; flores 11-13, corola rosa a alva.

13.4. Vernonanthura subverticillata

3'. Brácteas involucrais em 7-9 séries; flores 25-27, corola creme

13.3. Vernonanthura polyanthes

13.1. Vernonanthura brasiliana (L.) H.Rob., Phytologia 73(2): 69. $1992 . \quad$ Fig. $4 \mathrm{i}$

Arbusto, 1,5-3 m alt. Ramos quadrangulares, estriados, tomentosos a glabrescentes. Folhas alternas, pecioladas, pecíolo $0,2-0,5 \mathrm{~cm}$ compr.; lâmina foliar 2,5-6 × 1,2-3,6 cm, coriácea, concolor, obovada ou elíptica, ápice mucronado a obtuso, margem denticulata, revoluta, base atenuada, face adaxial esparsamente estrigosa e face abaxial densamente estrigosa. Capitulescência paniculiforme. Capítulos pedunculados, pedúnculo $0,5-1,5 \mathrm{~cm}$ compr. Invólucro 5-6 $\times 7-8 \mathrm{~mm}$, campanulado; brácteas involucrais $78-80,8$ séries, imbricadas, externas ovadas, $1,3-2,8 \times 0,4-0,9 \mathrm{~mm}$, internas lanceoladas, $4-5$ $\times 0,8-1 \mathrm{~mm}$, ápice acuminado, margem inteira, base cuneada, esverdeadas com ápice vináceo, seríceas. Receptáculo plano, fimbriado. Flores ca. 41 , corola 4,8-6,5 $\mathrm{mm}$ compr., rósea, glabra, tubo 2-2,5 mm compr., limbo 1-2 mm compr., lacínias 1,8-2 mm compr. Antera 2,3-2,7 mm compr., apêndice do conectivo acuminado, 0,5-0,7 mm compr., base calcarada. Estilete 4,2-7 mm compr., róseo, ramos do estilete lineares $1,3-1,5 \mathrm{~mm}$ compr., ápice agudo. Cipsela 1-1,5 mm compr., prismática, estrigosa, 10-costada; carpopódio simétrico, anuliforme. Pápus bisseriado, série externa ca. $0,4 \mathrm{~mm}$ compr., paleácea, série interna ca. $5 \mathrm{~mm}$ compr., cerdoso-barbelado, persistentes, creme.

Material selecionado: Rio Ventura, $11^{\circ} 40^{\prime} 36^{\prime \prime} \mathrm{S}$, 4059'58”'W, 703 m, 16.IX.2015, M.G. Staudt et al. 106 (ALCB, HUEFS).

Vernonanthura brasiliana diferencia-se de Vernonanthura ferruginea (Less.) H.Rob.pelo indumento estrigoso (vs. denso-tomentoso) nos ramos e folhas, número de brácteas involucrais (78-80 vs. 55) e número de flores por capítulos (41 vs. 25), respectivamente (Ogasawara \& Roque 2015). A espécie possui distribuição na Bolívia, Colômbia, Guiana, Suriname, Venezuela e no Brasil (Funk et al. 2007). Na Bahia ocorre em remanescente de Floresta Ombrófila Densa, restinga, mata ciliar, carrasco, Caatinga, Cerrado e em áreas antropizadas (Ogasawara \& Roque 2015). Em Morro do Chapéu foi coletada em área antropizada, caatinga e floresta estacional semidecidual. 
13.2. Vernonanthura laxa (Gardner) H.Rob., Phytologia 73(2): 71. 1992.

Arbusto, $50 \mathrm{~cm}$ alt. Ramos cilíndricos, estriados, vináceos. Folhas alternas, sésseis; lâmina foliar $8 \times 0,8 \mathrm{~cm}$, coriácea, discolor, com nervuras vináceas, estreito elíptica, ápice agudo, margem inteira, base cuneada, face adaxial pubescente e face abaxial tomentosa. Capitulescência em racemos corimbiformes. Capítulos pedunculados, pedúnculo ca. 1,5 mm compr. Invólucro campanulado; brácteas involucrais 21-28, 6 séries, imbricadas, externas ovadas, 2,5 × 1,2 mm, internas lanceoladas, 3,3 $\times 1,7 \mathrm{~mm}$, ápice agudo a acuminado, margem inteira, base truncada, esverdeadas com ápice vináceo, pubescente a glabrescente com tricomas glandulares sésseis no ápice. Receptáculo plano. Flores ca.10, corola 5,5-8 $\mathrm{mm}$ compr., lilás, com tricomas glandulares sésseis, tubo $2-3 \mathrm{~mm}$ compr., limbo 1-2 mm compr., lacínias 1,5-3 mm compr. Antera 3,2-3,4 mm compr., apêndice do conectivo 0,6-0,8 $\mathrm{mm}$ compr., ápice agudo, base calcarada. Estilete ca. 9,5 mm compr., lilás, ramos do estilete ca. 2,2 $\mathrm{mm}$ compr., lineares, ápice agudo. Cipsela ca. $3 \mathrm{~mm}$ compr., estrigosa, tricomas glandulares sésseis, 10-costada; carpopódio anuliforme. Pápus bisseriado, série externa paleáceo, $0,4-0,7 \mathrm{~mm}$ compr., série interna cerdoso-barbelado, 5-6 $\mathrm{mm}$ compr., persistentes, creme.

Material examinado: $11^{\circ} 58^{\prime} 33^{\prime \prime} \mathrm{S}, 41^{\circ} 16^{\prime} 67^{\prime \prime} \mathrm{W}$, 1.VI.1983, E.E. de Miranda 13 (HUEFS).

Vernonanthura laxa é reconhecida pelas folhas sésseis, lâmina foliar estreito-elíptica e capitulescência em racemos corimbiformes (Ogasawara \& Roque 2015). A espécie é exclusiva do Brasil, com distribuição na Bahia, Minas Gerais e Paraná (BFG 2018). Na Bahia, ocorre principalmente na Chapada Diamantina em vegetação campestre, como cerrado e campos gerais (BFG 2018).

13.3. Vernonanthura polyanthes (Spreng.) A.J.Vega \& M.Dematt., Phytotaxa 8: 47. 2010.

Figs. 4j; 5a

Arbusto ca. $2 \mathrm{~m}$ alt. Ramos cilíndricos, estriados, tomentosos. Folhas alternas, pecioladas, pecíolo 0,2-1 cm compr.; lâmina foliar 5,5-17,7 $\times 1,7-2 \mathrm{~cm}$, cartácea, discolor, elíptica, ápice agudo, margem denticulata, base atenuada, face adaxial estrigosa e face abaxial tomentosa. Capitulescência paniculiforme. Capítulos sésseis. Invólucro 6-7 × 5-6 $\mathrm{mm}$, campanulado; brácteas involucrais 59-62, 7-9 séries, imbricadas, externas ovadas $1,2-1,6 \times 0,7-0,9 \mathrm{~mm}$, internas lanceoladas 3,8-5 × 1,2-1,5 $\mathrm{mm}$, ápice agudo a acuminado, margem inteira, base, tomentosas a glabrescentes, esverdeadas com ápice castanho. Receptáculo plano, fimbriado. Flores 25-27, corola 3,2-4,1 mm compr., glabra, creme, tubo 1-1,5 mm compr., limbo ca. $1 \mathrm{~mm}$ compr., lacínias 1,2-1,6 mm compr. Antera ca. $3 \mathrm{~mm}$ compr., apêndice do conectivo agudo, base calcarada. Estilete 2,8-3,8 mm compr., creme, ramos do estilete lineares, ca. $2 \mathrm{~mm}$ compr., ápice agudo. Cipsela 0,5-1 mm compr., obcônica, 10-costada; carpopódio simétrico, anuliforme. Pápus bisseriado, série externa paleácea, 1,2-1,8 $\mathrm{mm}$ compr., série interna cerdoso-barbelado, 4-4,5 mm compr., persistente, creme.

Material selecionado: Gruta do Cristal, 11\%49'13"S, 49 18'44”W, 12.VII.2008, F. França et al. 5851 (HUEFS).

Vernonanthura polyanthes se assemelha a Vernonanthura membranacea (Gardner) H.Rob. pela lâmina foliar elíptica, capitulescência paniculiforme, capítulos sésseis, número de flores por capítulo (ca. 20 vs. 20-29) e corola creme (Baker 1873). Diante da falta de caracteres diagnósticos para separar as espécies, Ogasawara \& Roque (2015) optaram por considerar apenas $V$. polyanthes para as espécies da Bahia. A espécie tem ocorrência na Bolívia e no Brasil e é amplamente distribuída nos estados do sudeste e na Bahia, principalmente em vegetação campestre e de floresta estacional semidecidual na Chapada Diamantina e Mata Atlântica (BFG 2018; Ogasawara \& Roque 2015). Em Morro do Chapéu ocorre em área de caatinga.

13.4. Vernonanthura subverticillata (Sch.Bip. ex Baker) H.Rob., Phytologia 73(2): 74. 1992.

Figs. 5b,c

Arbusto, 1,5m alt. Ramos cilíndricos, estriados, tomentosos. Folhas alternas, pecioladas, pecíolo $0,3-0,5 \mathrm{~cm}$ compr.; lâmina foliar 3,5-5,8 $\times 1,7-2,6 \mathrm{~cm}$, coriácea, discolor, elíptica, ápice agudo, margem serreada a serrulada, base atenuada, face adaxial estrigosa, face abaxial tomentosa. Capitulescência paniculiforme. Capítulos curto pedunculados, pedúnculo ca. 0,5 mm compr. Invólucro 4-5 × 4,7-7 $\mathrm{mm}$, campanulado; brácteas involucrais $22-28,5$ séries, imbricadas, externas $1,2-2 \times 0,4-0,8$ $\mathrm{mm}$, internas $3-3,8 \times 1-1,2 \mathrm{~mm}$, lanceoladas, ápice acuminado, margem inteira, esverdeadas 
com ápice castanho, seríceas. Receptáculo plano, fimbriado. Flores 11-13, corola 4,3-5,2 mm compr., rósea a alva, tubo ca. $2 \mathrm{~mm}$ compr., limbo ca. 1,2 mm compr., lacínias ca. $2 \mathrm{~mm}$ compr. Antera ca. $3 \mathrm{~mm}$ compr., apêndice do conectivo ca. 0,6 mm compr., ápice agudo a acuminado, base calcarada. Estilete 4-6,8 mm compr., ramos do estilete lineares, ca. 1,7 mm compr., ápice acuminado. Cipsela 1,2-2,3 mm compr., prismática, estrigosa, 10-costada; carpopódio simétrico, anuliforme. Pápus bisseriado, série externa paleácea, 0,4-0,7 mm compr., série interna cerdoso-barbelado, 2,8-4,2 mm compr., persistente, creme.

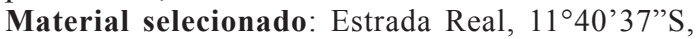
41 05 '13”W, 23.II.2013, H.A. Ogasawara et al. 336 (ALCB, HUEFS).

Vernonanthura subverticillata diferenciase de Vernonanthura mariana (Mart. ex Baker) H.Rob. pela lâmina foliar elíptica, ápice agudo, brácteas involucrais acuminadas e cipselas estrigosas (vs. lâmina foliar obovada, ápice cuspidado, brácteas involucrais obtusas a cuspidadas e cipselas com tricomas glandulares) (Ogasawara \& Roque 2015). A espécie é endêmica do Brasil e possui distribuição na Bahia, Minas Gerais, Brasília e Paraná (BFG 2018). Na Bahia ocorre principalmente na Chapada Diamantina, em vegetação de de cerrado, campos rupestres, Mata Atlântica e floresta estacional semidecidual (BFG 2018). Em Morro do Chapéu foi encontrada em áreas de caatinga e de transição entre cerrado e campo rupestre.

\section{Estudo taxonômico da tribo Eupatorieae}

\section{Eupatorieae Cass.}

Eupatorieae caracteriza-se pelas folhas usualmente simples e opostas, invólucro imbricado, subimbricado a eximbricado, receptáculo plano ou convexo, paleáceo ou epaleáceo, capítulos homógamos, discóides, flores que variam de 1 a mais de 100, tubulosas, actinomorfas, raramente zigomorfas, alvas a róseas ou lilás, apêndices basais das anteras curtos, frequentemente ausentes, colar da antera apresenta muitas variações na forma, ramos do estilete longos, exsertos, lineares a clavados, superfície papilosa, geralmente da mesma cor da corola, cipsela com uma camada de células enegrecidas por fitomelanina, carpopódio bem desenvolvido e pápus simples, usualmente persistente (King \& Robinson 1987; Hind \& Robinson 2007).
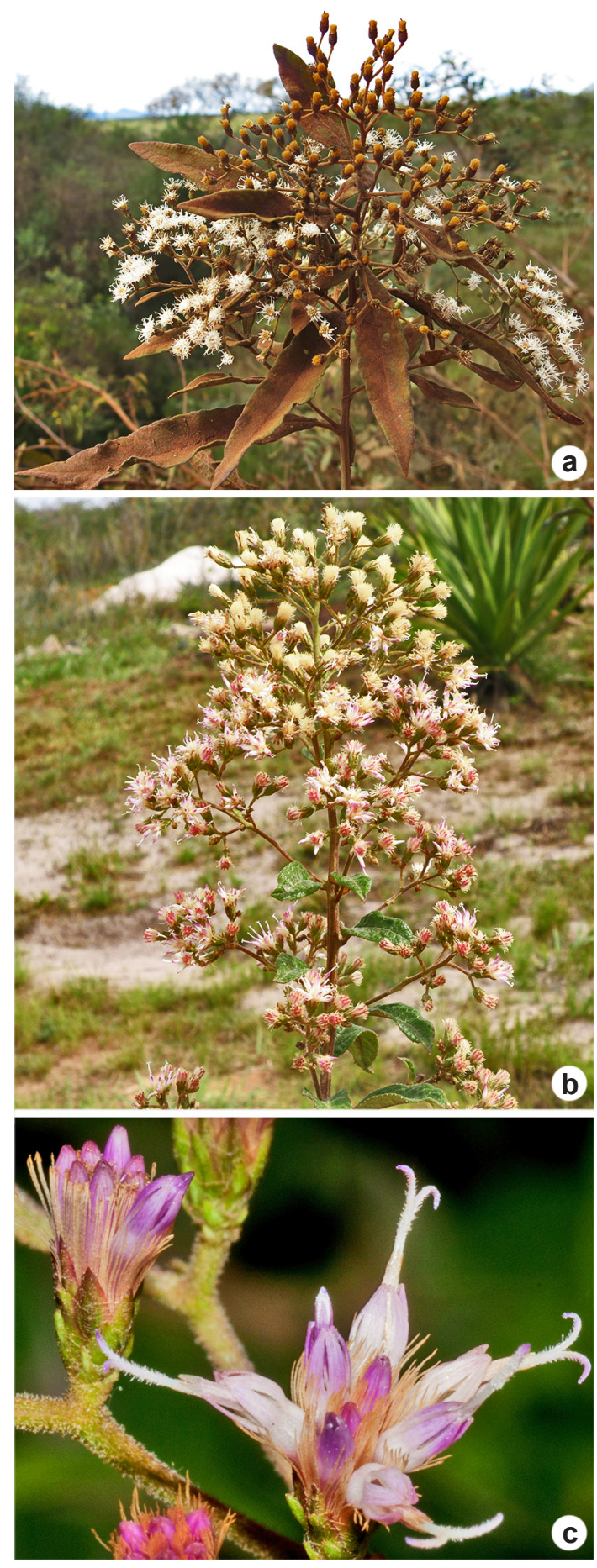

Figura 5 - a. Vernonanthura polyanthes. b, c. Vernonanthura subverticillata. (a. L. Moura; b. H. Ogasawara; c. L. Pataro).

Figure 5 - a. Vernonanthura polyanthes. b, c. Vernonanthura subverticillata. (a. L. Moura; b. H. Ogasawara; c. L. Pataro). 


\section{Chave de identificação dos gêneros da tribo Eupatorieae no Morro do Chapéu, Bahia, Brasil}

1. Brácteas involucrais em mesmo número que o de flores.

2. Capítulos com 4 brácteas involucrais e 4 flores. 10. Mikania

2'. Capítulos com 5 brácteas involucrais e 5 flores 14. Stevia

1'. Brácteas involucrais em número diferente ao de flores.

3. Ramos do estilete com pilosidade abaixo do ponto de bifurcação

15. Stylotrichium

3'. Ramos do estilete sem pilosidade abaixo do ponto de bifurcação.

4. Lâmina foliar com venação sub-paralela; brácteas involucrais e páleas terminadas em apêndices apicais cartáceos sinuosos 13. Scherya

4'. Lâmina foliar com venação peninérvea ou acródoma; brácteas involucrais e páleas sem apêndices apicais.

5. Receptáculo paleáceo; pápus aristado, coroniforme, coroniforme-aristado ou ausente . 1. Acritopappus

5'. Receptáculo epaleáceo; pápus cerdoso, cerdoso-barbelado ou paleáceo-aristado.

6. Capítulos com 58-75 flores, pápus com 5 páleas aristadas

2. Ageratum

6'. Capítulos com 4-28 flores; pápus cerdoso ou cerdoso-barbelado.

7. Invólucro com 30-36 brácteas involucrais

6. Chromolaena

7'. Invólucro com 7-20 brácteas involucrais.

8. Cipsela obcônica com tricomas vesiculares; pápus bisseriado 16. Symphyopappus

8'. Cipsela cilíndrica sem tricomas vesiculares; pápus unisseriado.

9. Lacínias da corola densamente pubescentes; cipsela estipitada, pápus plumoso 17. Trichogonia

9'. Lacínias da corola glabras ou com tricomas glandulares sésseis; cipsela não estipitada; pápus cerdoso ou cerdoso-barbelado.

10. Folha séssil, lâmina foliar acicular a linear, margem inteira.

11. Brácteas involucrais $22,2-4$ séries; receptáculo convexo ou cônico; flores com corola lilás a rosa.... 3. Agrianthus

11'. Brácteas involucrais 12-14, 5 séries; receptáculo plano; flores com corola creme 12. Pseudobrickellia

10'. Folha peciolada, lâmina foliar obovada, ovada, lanceolada, elíptica, margem crenada, denteada ou serreada no $1 / 3$ superior.

12. Plantas viscosas; cipsela glabra 4. Bahianthus

12'. Plantas sem viscosidade; cipsela pilosa ou com tricomas glandulares sésseis e estipitados.

13. Folhas congestas no ápice dos ramos; lâmina foliar orbicular a obovada, crassa, concolor .... 9. Lapidia

13'. Folhas dispostas ao longo de todo o caule; lâmina foliar ovada, membranácea, discolor.

14. Lâmina foliar com margem denteada e base oblíqua; corola com projeções papilosas no interior das lacínias 11. Prolobus

14'. Lâmina foliar com margem, serreada, crenada e base truncada, cordada; corola glabra no interior das lacínias.

15. Folha com face abaxial vilosa, setosa; capítulo com 16-35 flores.

16. Folhas alternas; capitulescência corimbiforme, corola lilás; receptáculo cônico 7. Conocliniopsis 
16'. Folhas opostas; capitulescência glomeruliforme; corola alva: receptáculo plano

15'. Folha com face abaxial tomentosa; capítulo com 4-5 flores.

5. Bejaranoa

\section{Acritopappus R.M.King \& H.Rob.}

Acritopappus é caracterizado pelo receptáculo paleáceo e pelo pápus que varia de coroniforme a aristado ou ausente. Geralmente são árvores e arbustos que ocorrem quase com exclusividade nas regiões Nordeste e Sudeste do Brasil (Bautista
2000). No Brasil são registradas 19 espécies, sendo que destas, 15 ocorrem na Bahia (BFG 2018; Bautista et al. 2017). Em Morro do Chapéu são registradas cinco espécies e, dentre elas, duas são endêmicas do município.

\section{Chave de identificação das espécies de Acritopappus}

1. Pápus aristado (2-5 aristas caducas) ou ausente.

2. Lâmina foliar lanceolada (6,5-13 cm compr.), conduplicada, ápice caudado, margem serreada, base atenuada; pápus aristado, aristas caducas ..... 1.1. Acritopappus confertus

2'. Lâmina foliar elíptica a obovada (3-5,5 cm compr.), plana, ápice obtuso a apiculado, margem serrulada, base arredondada; pápus ausente. 1.4. Acritopappus prunifolius

1'. Pápus coroniforme.

3. Ramos subhexagonais; 20-29 brácteas involucrais; capítulos com 20-26 flores; receptáculo convexo; páleas no receptáculo 15-21 1.2. Acritopappus heterolepis

3'. Ramos cilíndricos; 5-7 brácteas involucrais; capítulos com 5-8 flores; receptáculo plano; páleas no receptáculo 1-2.

4. Lâmina foliar deltóide a ovada, plana

1.5. Acritopappus santosii

4'. Lâmina foliar elíptica, conduplicada 1.3. Acritopappus jacobaeus

1.1. Acritopappus confertus (Gardner) R.M.King \& H.Rob., Phytologia 24(5): 402. 1972. Fig. 6a Arbusto ou árvore, 0,7-4 m alt. Ramos cilíndricos, estriados, com cicatrizes deixadas pelas folhas, pubescentes a glabrescentes, com tricomas glandulares sésseis. Folhas opostas, pecioladas, pecíolo $1,2-1,8 \mathrm{~cm}$ compr.; lâmina foliar $6,5-13 \times 1-2,5 \mathrm{~cm}$, coriácea, resinosas, levemente discolor, lanceolada, conduplicada, ápice caudado, margem serreada, base atenuada, nervura principal proeminente na face abaxial e impressa na face adaxial, glabra em ambas as faces. Capitulescência corimbiforme. Capítulos sésseis. Invólucro 3,55 × 2,1-3,5 mm, cilíndrico, bisseriado; brácteas involucrais $6-8$, sub-iguais, externas $2,8-3,2 \times 0,6-1,3 \mathrm{~mm}$, internas $3,5-4,1$ $\times 0,8-1,2 \mathrm{~mm}$, oblongas a oblanceoladas, ápice agudo a obtuso, margem ciliada, esverdeadas, pubescentes. Receptáculo plano, paleáceo, 2-4 páleas, lineares a estreito-oblanceoladas, ápice agudo a obtuso, margem inteira a ciliada, 3,2-4,2 $\times 0,2-04 \mathrm{~mm}$, planas, persistentes. Flores 6-9, corola $2,4-3,7 \mathrm{~mm}$ compr., rósea a alva, papilosa com tricomas glandulares sésseis e estipitados, tubo 1-1,5-2 mm compr., limbo 1-1,3 mm compr., lacínias triangulares, $0,3-0,4 \mathrm{~mm}$ compr. Antera 1,5-2,2 mm compr., apêndice do conectivo obtuso, mais longo que largo, base arredondada, colar da antera cilíndrico. Estilete 3,8-7 mm compr., glabra, alvo, ramos do estilete clavados, papilosos. Cipsela 1,2-2,9 mm compr., cilíndrica, glabra, 5-costada; carpopódio simétrico. Pápus unisseriado, ca. $1 \mathrm{~mm}$ compr., aristado, $2-5$ aristas, caducas.

Material selecionado: Cachoeira Ferro Doido,

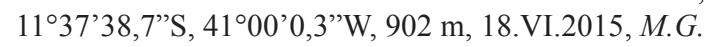
Staudt et al. 70 (ALCB, HUEFS).

As espécies A. confertus e Acritopappus catolesensis D.J.N.Hind \& Bautista são semelhantes morfologicamente e ambas as espécies possuem folhas lanceoladas, conduplicadas e ápice caudado. Segundo Bautista (2000), A. catolesensis, difere de $A$. confertus por não possuir pápus e apresentar uma pálea por capítulo, mas considerando que $A$. confertus possui pápus caduco e não houve variação significativa do número de páleas no receptáculo entre os materiais analisados, optou-se por manter apenas a ocorrência de $A$. confertus A espécie ocorre 

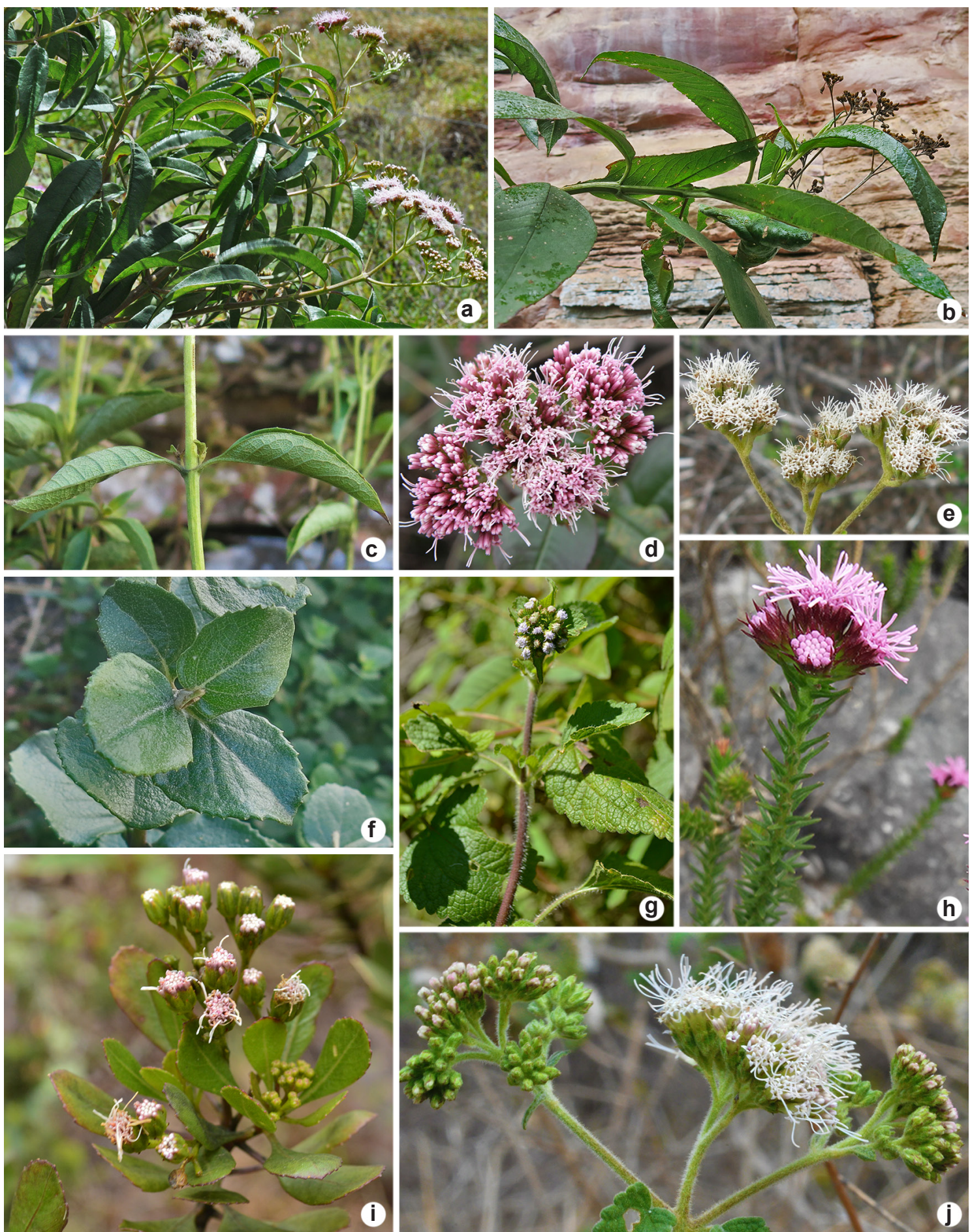

Figura 6 - a. Acritopappus confertus. b. Acritopappus heterolepis. c. Acritopappus jacobaeus. d. Acritopappus prunifolius. e, f. Acritopappus santosii. g. Ageratum conyzoides. h. Agrianthus empetrifolius. i. Bahianthus viscosus. j. Bejaranoa semistriata. (a, j. L. Barres; b. M. Alves; c. N. Roque; d. H. Ogasawara; e, f. M. Staudt; g. A. Gandara; h. V. Amorim; i. L. Moura).

Figure 6 - a. Acritopappus confertus. b. Acritopappus heterolepis. c. Acritopappus jacobaeus. d. Acritopappus prunifolius. e, f. Acritopappus santosii. g. Ageratum conyzoides. h. Agrianthus empetrifolius. i. Bahianthus viscosus. j. Bejaranoa semistriata. (a, j. L. Barres; b. M. Alves; c. N. Roque; d. H. Ogasawara; e, f. M. Staudt; g. A. Gandara; h. V. Amorim; i. L. Moura). 
na Região Nordeste do Brasil, nos estados da Bahia, Ceará, Pernambuco e Sergipe. Na Bahia é amplamente distribuída desde o litoral até a Chapada Diamantina (Bautista 2000). Em Morro do Chapéu, forma grandes populações que florescem e frutificam o ano todo, em vegetação de campo rupestre e áreas de transição de cerrado.

\subsection{Acritopappus heterolepis (Baker) R.M.King} \& H.Rob., Phytologia 45(2): 142. 1980. Fig. 6b Arbusto a árvore $1-3,5 \mathrm{~m}$ alt. Ramos subhexagonais, estriados, pubescentes. Folhas opostas, pecioladas, pecíolo 1-2,5 cm compr.; lâmina foliar $6,5-27,5 \times 3,5-10 \mathrm{~cm}$, coriácea, discolor, elíptica, ápice apiculado a caudado, margem dentada, base oblíqua a atenuada, face adaxial glabra, abaxial tomentosa, nervação alveolar. Capitulescência corimbiforme. Capítulos pedunculados, pedúnculo 0,3-1 $\mathrm{mm}$ compr. Invólucro 3-5 × 3-4,5 mm, campanulado; brácteas involucrais 20-29, sub-iguais, 2-3 séries, externas 3,5-4 ×0,5-0,8 mm, internas 3-3,7 $\times 0,9-1,1 \mathrm{~mm}$, elípticas a lanceoladas, ápice agudo a obtuso, margem ciliada, esverdeadas, tricomas glandulares sésseis. Receptáculo convexo, paleáceo, $15-21$ páleas, 4-4,6 ×0,4-0,7 $\mathrm{mm}$, planas, persistentes. Flores 20-26, corola 2,7-4 mm, lilás, tricomas glandulares sésseis e estipitados, tubo 1,3-2 mm compr., limbo 1-1,5 $\mathrm{mm}$ compr., lacínias com lobos triangulares, ca. 0,4 mm compr., papilosa. Antera 1,3-1,8 $\mathrm{mm}$ compr., apêndice do conectivo agudo, mais longo que largo, base sagitada, colar da antera cilíndrico. Estilete 5,5-7 mm compr., glabra, ramos do estilete lineares, ápice obtuso. Cipsela 2-2,5 mm compr., prismática, tricomas glandulares sésseis, 4-costada; carpopódio simétrico, anuliforme. Pápus unisseriado, 0,4-0,9 mm compr., coroniforme-aristado.

Material selecionado: Fazenda Boa Esperança, 11 ${ }^{\circ} 54$ '59,3”'S, 41 ${ }^{\circ} 07$ '16,4”'W, 904 m, 28.XI.2015, M.G. Staudt et al. 126 (ALCB, HUEFS).

Acritopappus heterolepis diferencia-se das demais espécies do gênero encontradas em Morro do Chapéu pelo tamanho maior da lâmina foliar, receptáculo convexo e maior número de páleas do receptáculo e de flores do capítulo. A espécie é endêmica da Bahia e possuiu ampla distribuição na Chapada Diamantina (Bautista 2000). Na área de estudo, esta espécie foi encontrada em encostas de morro e em áreas de transição entre caatinga e floresta estacional semidecidual, com altitudes em torno de $1.200 \mathrm{~m}$.
1.3. Acritopappus jacobaeus Bautista, Rodr. Oubinã \& S.Ortiz, Phytotaxa 311 (1): 022-028. 2017.

Fig. 6c

Arbusto ca. $60 \mathrm{~cm}$ alt. Ramos cilíndricos, estriados, tomentosos. Folhas opostas, pecioladas, pecíolo $0,2-0,5 \mathrm{~cm}$ compr.; lâmina foliar 2,7-6,5 × 1,5-3 cm, coriácea, concolor, elíptica, conduplicada, ápice agudo, margem serreada, terço proximal inteira, base atenuada, nervação proeminente, alveolar, face adaxial glabra, abaxial tomentosa. Capitulescência corimbiforme. Capítulos sésseis. Invólucro 5-6 $\times 2-2,5 \mathrm{~mm}$, cilíndrico; brácteas involucrais 5-7, verdes, externas 3,2-6 × 0,9-2 mm, elípticas a oblanceoladas, ápice agudo, margem ciliada, tomentosas. Receptáculo plano, paleáceo, 2 páleas, lanceolada, ápice acuminado, margem ciliada, ca. $5 \times 0,5 \mathrm{~mm}$, planas, persistentes. Flores 6-8, corola tubulosa, corola $3,8-4,5 \mathrm{~mm}$ compr., alva, pubérula, tubo ca. $2 \mathrm{~mm}$ compr., limbo ca. 1,2 mm compr., lacínias triangulares, 0,6 mm compr., glabras. Antera ca. 1,8 mm compr., apêndice do conectivo obtuso, mais longo que largo, base arredondada, colar da antera cilíndrico. Estilete ca. 2,3 mm compr., glabro, ramos do estilete clavados, papilosos; Cipsela 2,2-3 mm compr., cilíndrica atenuada, 5-costada; carpopódio decorrente, proeminente. Pápus unisseriado, coroniforme, 0,7-0,9 mm compr.

Material selecionado: Fazenda Areia Branca, 11'33'50'S, 41 '10'46”'W, 1.087 m, 17.IX.2015, M.G. Staudt et al. 114 (ALCB, HUEFS).

Acritopappus jacobaeus assemelha-se morfologicamente a Acritopappus micropappus (Baker) R.M.King \& H.Rob, mas pode ser facilmente diferenciada pelas folhas pecioladas (vs. sésseis), número de páleas (2-3 vs. 11-13) e flores do capítulo (5-6 vs. 18-20) (Bautista 2000; Bautista et al. 2017). A espécie é endêmica de Morro do Chapéu e ocorre em área de transição entre campo rupestre e floresta estacional semidecidual e em caatinga sob solo arenoso.

\subsection{Acritopappus prunifolius R.M.King \&} H.Rob., Phytologia 45: 144. 1980 . Fig. 6d

Arbusto ca. $3 \mathrm{~m}$ alt. Ramos cilíndricos, estriados, pilosos a glabrescentes. Folhas opostascruzadas, pecioladas, pecíolo 0,5-1 cm compr.; lâmina foliar 3-5,5 × 1,8-2,5 cm, coriácea, concolor, elíptica a obovada, ápice obtuso a apiculado, margem serrulada, base arredondada, face adaxial glabra e face abaxial pubescente com tricomas glandulares sésseis. Capitulescência 
glomeruliforme. Capítulos sésseis. Invólucro ca. $5 \times 2,5 \mathrm{~mm}$, cilíndrico; brácteas 6,2-3 séries, verdes, 4-4,5 × 1-1,8 mm, lanceoladas, ápice agudo a apiculado, margem inteira, glabras. Receptáculo plano, paleáceo, 1-2 páleas, ca. 4,2 $\times 1 \mathrm{~mm}$, planas, persistentes. Flores ca. 6 , corola 3-3,2 mm compr., rósea a alva, pilosa, tubo ca. 1 $\mathrm{mm}$, limbo ca. 1,5 mm compr., lacínias com lobos triangulares, ca. 0,5 mm compr. Antera ca. 1,5 mm compr., apêndice do conectivo obtuso, tão longo quanto largo, base arredondada, colar da antera cilíndrico. Estilete ca. 2,8 mm compr., ramos do estilete lineares, ápice obtuso, papilosos. Cipsela 1,8-2,3 mm compr., prismática, glabra, 5-costada; carpopódio anuliforme. Pápus ausente.

Material selecionado: Morrão, $11^{\circ} 33^{\prime} \mathrm{S}, 41^{\circ} 09^{\prime} \mathrm{W}$, 19.I.2013, M.L. Guedes et al. 20289 (ALCB, HRB).

Acritopappus prunifolius é distinguida das demais espécies do gênero por apresentar lâmina foliar elíptica a obovada com margem serrulada, sem viscosidade e pápus ausente. Segundo Bautista (2000), a espécie que mais se assemelha é Acritopappus buiquensis Bautista \& D.J.N.Hind, que apresenta os capítulos solitários e pedicelados, com ca. 25 flores e pápus aristado a coroniforme-aristado, enquanto os capítulos de $A$. prunifolius são sésseis e condensados em glomérulos, com cerca de cinco flores e pápus ausente. Acritopappus prunifolius tem Morro do Chapéu como localidade-tipo e é endêmica da Chapada Diamantina, sendo encontrada em campos gerais e floresta estacional semidecidual. $\mathrm{Na}$ área de estudo foi coletadaem área de transição entre cerrado e campo rupestre.

1.5. Acritopappus santosii R.M.King \& H.Rob., Phytologia 45(2):145.1980.

Fig. 6e,f

Arbusto 0,8-3 m alt. Ramos cilíndricos, estriados, tomentosos. Folhas opostas, subsésseis a pecioladas, pecíolo ca. $0,5 \mathrm{~cm}$ compr.; lâmina foliar 1,5-10 × 1,8-8,2 cm, coriácea, discolor, deltoide a ovada, plana, ápice obtuso a apiculado, margem denteada, base atenuada a truncada, face adaxial pubérula com tricomas glandulares sésseis, face abaxial tomentosa. Capitulescência corimbiforme. Capítulos sésseis. Invólucro 5-5,5 × 2,7-3,5 mm, cilíndrico, bisseriado, brácteas involucrais 6-7, sub-iguais, 3,2-5,5 × 0,8-1,7 mm, lanceoladas a oblanceoladas, ápice apiculado, margem ciliada, esverdeadas com ápice róseo, face adaxial pubérula e face abaxial tomentosa. Receptáculo plano, paleáceo, 1 pálea, linear, ápice acuminado, margem ciliada, ca. $6 \times 0,5 \mathrm{~mm}$, plana, persistente. Flores 5-6, corola 3,8-4,1 mm compr., lilás a alva, setosa com tricomas glandulares sésseis, tubo ca. $2 \mathrm{~mm}$ compr., limbo ca. 1,3 mm compr., lacínias com lobos triangulares, ca. 0,5 mm compr., papilosas. Antera 1,7-2 mm compr., apêndice do conectivo obtuso, tão longo quanto largo, base sagitada, colar da antera cilíndrico. Estilete 6,4-7,2 mm, glabra, ramos do estilete clavados, papilosos. Cipsela 3-3,2 mm compr., cilíndrica com tricomas glandulares sésseis, 5-costada; carpopódio simétrico, anuliforme. Pápus uniserriado, 04-1 mm compr., coroniforme.

Material selecionado: Morrão, $11^{\circ} 35^{\prime} 27,7$ 'S, $41^{\circ} 12^{\prime} 30,5^{\prime \prime} \mathrm{W}, 1.265 \mathrm{~m}, 19 . \mathrm{III} .2016$, M.G. Staudt et al. 158/159/160/161/162 (ALCB, HUEFS).

Acritopappus santosii é distinta das demais espécies por suas folhas com lâmina foliar deltoide a ovada e segundo Bautista (2000), a espécie pode ser diferenciada de A. micropappus. pelo número de flores por capítulo 5-9 (vs. 18-20), apêndice da antera obtuso (vs. agudo) e colar da antera cilíndrico ( $v s$. trapezóide), respectivamente. Floresce e frutifica durante vários períodos do ano. Acritopappus santosii é endêmica de Morro do Chapéu e ocorre em áreas de campo rupestre e ecótonos, formando grandes populações, geralmente associadas a $A$. confertus.

\section{Ageratum L.}

O gênero pode ser reconhecido pelo receptáculo cônico, folhas com pontuações glandulares, apêndice do conectivo da antera mais longo que largo, carpopódio fortemente assimétrico e pápus 5-aristado, coroniforme ou ausente (King \& Robinson 1987). O gênero possui ca. 40 espécies que ocorrem na América Central e do Sul (Hind \& Robinson 2007) e quatro espécies no Brasil e na Bahia (BFG 2018). Em Morro do Chapéu há registro de uma espécie.

\subsection{Ageratum conyzoides L., Sp. P1. 2: 839.} 1753.

Fig. $6 \mathrm{~g}$

Erva 20-80 cm alt. Ramos cilíndricos, estriados, pilosos a glabrescentes, verdes a vináceos. Folhas opostas, pecioladas, pecíolo 1,4-3,8 cm compr.; lâmina foliar 3-8,6 × 2-5,4 $\mathrm{cm}$, membranácea, levemente discolor, elíptica a oblonga, ápice agudo, margem crenada a serreada, base blíqua a obtusa, pilosa a glabrescente. Capitulescência umbeliforme. Capítulos pedunculados, pedúnculo $0,8-1,3 \mathrm{~cm}$ compr. Invólucro $3,5-4 \times 5-5,5 \mathrm{~mm}$, campanulado, 
bisseriado; brácteas involucrais 22-26, 2 séries, externas $4-4,2 \times 0,8-0,9 \mathrm{~mm}$, lanceoladas, internas 3,5-4 × 0,2-0,3 $\mathrm{mm}$, lineares, margem ciliada, esverdeadas com ápice vináceo, glabras. Receptáculo cônico, epaleáceo; Flores 58-75, corola 1,7-2,2 mm compr., alva a lilás, setosa com tricomas glandulares sésseis, tubo 1-1,2 mm compr., limbo 0,8-0,9 mm compr., lacínias 0,1-0,2 mm compr. Antera 0,5-0,6 mm compr., apêndice do conectivo agudo, mais longo que largo, base ecaudada, colar da antera cilíndrico. Estilete 2-2,3 mm compr., glabro, ramos do estilete lineares, ápice obtuso, alvo a lilás, papilosos. Cipsela 1,4-2 mm compr., obcônica, 5-costada; carpopódio assimétrico. Pápus 2,1-2,3 mm compr., paleáceo-aristado, 5 páleas aristadas. Material selecionado: trilha para o Ventura, 11'40'13,4'S, 4058'27'W, 701 m, 16.VI.2015, M.G. Staudt et al. 32 (ALCB, HUEFS).

Dentre as espécies que ocorrem no Brasil, a que mais se assemelha é Ageratum candidum G.M.Barroso, entretanto, A. conyzoides diferenciase pela lâmina foliar crenada a serreada ( $v s$. incisodenteada), pápus com 5 páleas (vs. 10 páleas) e corola setosa com tricomas glandulares ( $v s$. glabra) (Barroso 1965). A espécie distribui-se desde o México até a América do Sul, e no Brasil é encontrada em todos os estados e fitofisionomias (King \& Robinson 1987; BFG 2018). Na área de estudo foi coletada em borda de floresta estacional semidecidual.

\section{Agrianthus Mart. ex DC.}

Agrianthus caracteriza-se pelo receptáculo geralmente paleáceo, lâmina coriácea, invólucro (2)3-5 seriado, pápus cerdoso, raramente ausente ou defectivo (Hind 2000b). O gênero é endêmico dos campos rupestres da Cadeia do Espinhaço, sendo que das nove espécies descritas, oito são restritas à Chapada Diamantina na Bahia (Hind 2009). Em Morro do Chapéu há registro de uma espécie.

\subsection{Agrianthus empetrifolius Mart. ex DC., Prodr.} 5: 126.1836.

Fig. 6h

Arbusto ca. $30 \mathrm{~cm}$ alt., ramos cilíndricos, estriados, setosos. Folhas alternas, densamente imbricadas, ascendentes, sésseis; lâmina foliar 1,1-1,4 × 0,1-0,2 cm, coriácea, concolor, acicular a linear, ápice agudo, margem inteira, revoluta, base truncada, glabra. Capitulescência corimbiforme. Capítulos pedunculados, pedúnculo 0,3-0,4 mm compr., bractéola 3,2-5 ×0,5-1 mm;
Invólucro $0,7-0,6 \times 0,5-0,6 \mathrm{~cm}$, campanulado; brácteas involucrais ca. 22, 3 séries, externas 3-4 × 0,8-1 mm, internas 4,4-4,8 $\times 0,4-0,5 \mathrm{~mm}$, lanceoladas, ápice agudo a acuminado, margem ciliada, esverdeadas, glabras. Receptáculo cônico, paleáceo, 2 páleas, lineares a estreito-lanceoladas, ápice acuminado, margem inteira, 5-6 × 0,5-0,8 $\mathrm{mm}$, planas, persistentes. Flores $18-33$, corola 3-3,3 mm compr., lilás a rosa, com tricomas glandulares sésseis, tubo 1,8-2 mm compr., limbo 1-1,2 mm compr., lacínias 0,2-0,3 mm compr., glabras. Antera 1,3-1,4 mm compr., apêndice do conectivo obtuso a retuso, mais longo que largo, base sagitada, colar da antera cilíndrico. Estilete 4,8-5,2 mm compr., glabra, ramos do estilete lineares, ápice obtuso, papilosos com tricomas glandulares. Cipsela 1,7-2,1 mm compr., prismática, 5-costada, setosa nas costelas; carpopódio assimétrico. Pápus bisseriado, série externa 1-1,5 mm compr., série interna 2,5-3 mm compr., cerdoso-barbelado, róseo a vináceo. Material examinado: Morrão, $11^{\circ} 35^{\prime} 63^{\prime} \mathrm{S}$, 4112'08'W, 1.025 m, 8.IX.2007, E. Melo et al. 5068 (HUEFS).

A espécie diferencia-se das outras do gênero pela lâmina foliar acicular a linear, estreita e revoluta e pelo pápus bisseriado (Hind 1995). Agrianthus empetrifolius é endêmica da Chapada Diamantina, Bahia (Hind 2009) e em Morro do Chapéu foi encontrada em área de campo rupestre.

\section{Bahianthus R.M.King \& H.Rob.}

4.1. Bahianthus viscosus (Spreng.) R.M.King \& H.Rob., Phytologia 23(3): 313. 1972 . Fig. 6i

Arbusto 1,5-4 m alt. Ramos cilíndricos, estriados, glabros, viscosos. Folhas alternas, espiraladas, viscosas, pecioladas, pecíolo 1,5-2 cm compr.; lâmina foliar 3-5,5 $\times$ 1,3-2,6 cm, coriácea, concolor, obovada, ápice obtuso ou truncado, acuminado, margem serreada no $1 / 3$ superior, base cuneada, glabra. Capitulescência paniculiforme a corimbiforme. Capítulos pedunculados, pedúnculo $1-3,5 \mathrm{~cm}$ compr. Invólucro 6-9 × 5-8 mm, hemisférico, subimbricado; brácteas involucrais 16-18, 3 séries, externas 4,5-3,5 × 1-1,2 mm, internas $6-5,5 \times 0,6-0,8 \mathrm{~mm}$, lineares a lanceoladas, ápice acuminado, base cuneada, margem inteira, esverdeadas, pilosas. Receptáculo cônico, epaleáceo. Flores 20-24, corola 4-4,3 mm compr, alva, glabra, tubo 1,7-2 mm compr., limbo 1,8-1,9 mm compr., lacínias triangulares, 0,4-0,5 mm compr., pubérulas. Antera 2,2 mm 
compr., apêndice do conectivo obtuso, tão longo quanto largo, base sagitada, colar da antera oblongo. Estilete 5,5-6 mm compr., ramos do estilete lineares, papilosos, ápice obtuso. Cipsela ca.3,3 mm compr., prismática, 4-costada, glabra; carpopódio anuliforme. Pápus ca. 4 mm compr.; persistente, unisseriado, cerdoso-barbelado.

Material selecionado: caminho do Ventura para a Cidade das Pedras, $11^{\circ} 33$ 'S, $41^{\circ} 09^{\prime} \mathrm{W}, 9 . X I I .2006$, M.L. Guedes et al. 16277 (ALCB).

Bahianthus é um gênero monoespecífico que apresenta folhas alternas, densamente espiraladas, viscosas, assim como os ramos, lâmina foliar obovada e serreada no terço superior (King \& Robinson 1987; Roque et al. 2016). Bahianthus viscosus é endêmica do Brasil e está distribuída nos domínios da Caatinga, do Cerrado e restinga na Bahia e no Espírito Santo. Na região de estudo foi encontrada nos campos rupestres.

\section{Bejaranoa R.M.King \& H.Rob.}

O gênero engloba duas espécies e apresenta lâmina foliar serreada e tomentosa, pequeno número de flores por capítulo (4-10), e cipsela com tricomas glandulares sésseis (King \& Robinson 1978, 1987). No Brasil, há registro de apenas uma espécie (BFG 2018).

5.1. Bejaranoa semistriata (Baker) R.M.King \& H.Rob., Phytologia 40: 53. 1978 . Fig. 6j

Arbusto 1,2-2,5 m alt.; ramos cilíndricos, estriados, tomentosos. Folhas alternas, pecioladas, pecíolo 0,3-0,5 cm compr.; lâmina foliar 1,5-7 × 0,5-2,5 cm, membranácea, fortemente discolor, ovada, ápice acuminado, margem crenada, base truncada, face adaxial tomentosa a glabrescente e face abaxial tomentosas com tricomas glandulares sésseis. Capitulescência corimbiforme. Capítulos pedunculados, pedúnculo $0,3-0,5 \mathrm{~cm}$ compr. Invólucro $0,3-0,4 \times 0,2-0,3 \mathrm{~cm}$, campanulado, bisseriado; brácteas involucrais 7-9, externas 3-4 × 1,5-2 mm, internas 2-2,5 × 1-1,5 mm, oblanceoladas, ápice acuminado, margem inteira, esverdeadas, estrigosas. Receptáculo plano, epaleáceo. Flores 4-5, corola 3,7-4,3 mm compr., roséa a alva, tricomas glandulares sésseis, tubo 2,8-3 mm compr., limbo 1-1,3 mm compr., lacínias 0,4-0,6 mm, papilosos. Antera 1,7-1,9 mm compr., apêndice do conectivo obtuso, mais longo do que largo, base truncada, colar da antera cilíndrico. Estilete ca. 0,8 cm compr., glabra, ramos do estilete lineares. Cipsela $2-3 \mathrm{~mm}$ compr., cilíndrica, com tricomas glandulares estipitados e sésseis, 5-costada; carpopódio anuliforme. Pápus $0,4 \mathrm{~cm}$ compr., unisseriado, cerdoso.

Material selecionado: Rio Ventura, $11^{\circ} 40$ '36,4”S, 4059'58,5”W, 703 m, 16.IX.2015, M.G. Staudt et al. 102 (ALCB, HUEFS).

Bejaranoa semistriata é endêmica do Brasil, com ocorrência apenas para o Cerrado e a Caatinga de Minas Gerais e Bahia (BFG 2018). Na área de estudo foi coletada em áreas de transição entre cerrado e campo rupestre.

\section{Chromolaena DC.}

Chromolaena pode ser caracterizado pelo invólucro com brácteas geralmente arredondadas e, pelo menos as mais internas, decíduas, receptáculo plano a levemente convexo e corola delgada (King \& Robinson 1987). O gênero possui ca. 165 espécies distribuídas desde o sul dos Estados Unidos até a América do Sul e tem o Brasil como um dos centros de diversidade do gênero com 72 espécies, sendo 12 registradas para a Bahia (King \& Robinson 1987; BFG 2018). Na área de estudo foram encontradas duas espécies.

\section{Chave de identificação das espécies de Chromolaena}

1. Lâmina foliar membranácea, ápice caudado, margem denteada, base atenuada; receptáculo convexo . 6.1. Chromolaena maximilianii

1'. Lâmina foliar coriácea, ápice agudo, margem inteira, base arredondada; receptáculo cônico 6.2. Chromolaena morii

6.1. Chromolaena maximilianii (Schrad. ex DC.) R.M.King \& H.Rob., Phytologia 49: 4. 1981.

Fig. $7 \mathrm{a}$

Arbusto decumbente, ca. 1,7 m alt. Ramos cilíndricos, estriados glabros a glabrescentes. Folhas opostas, pecioladas, pecíolo $0,4-1 \mathrm{~cm}$ compr., lâmina foliar 4-7× 1-3 cm, membranácea, discolor, ovada, ápice caudado, margem denteada, base atenuada, face adaxial setosa e face abaxial pilosa. Capitulescência paniculiforme. Capítulos pedunculados, pedúnculo $1,2-2,1 \mathrm{~cm}$ compr. Invólucro 10-12 × 4-5 mm, cilíndrico, imbricado, 

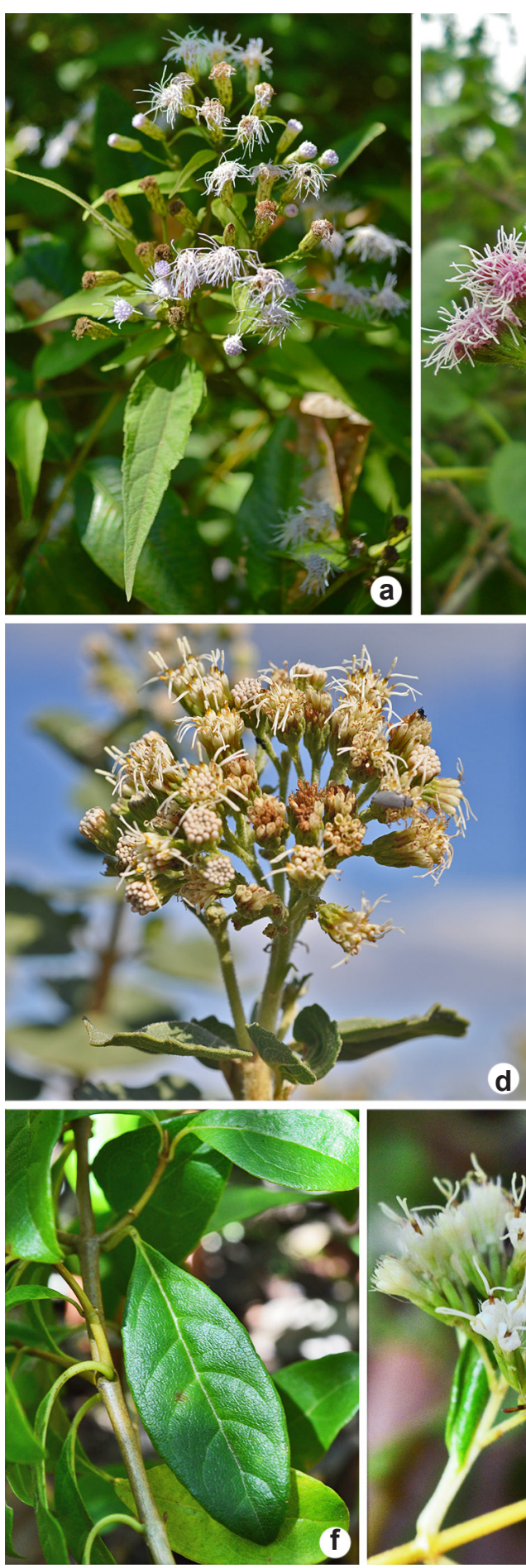

()
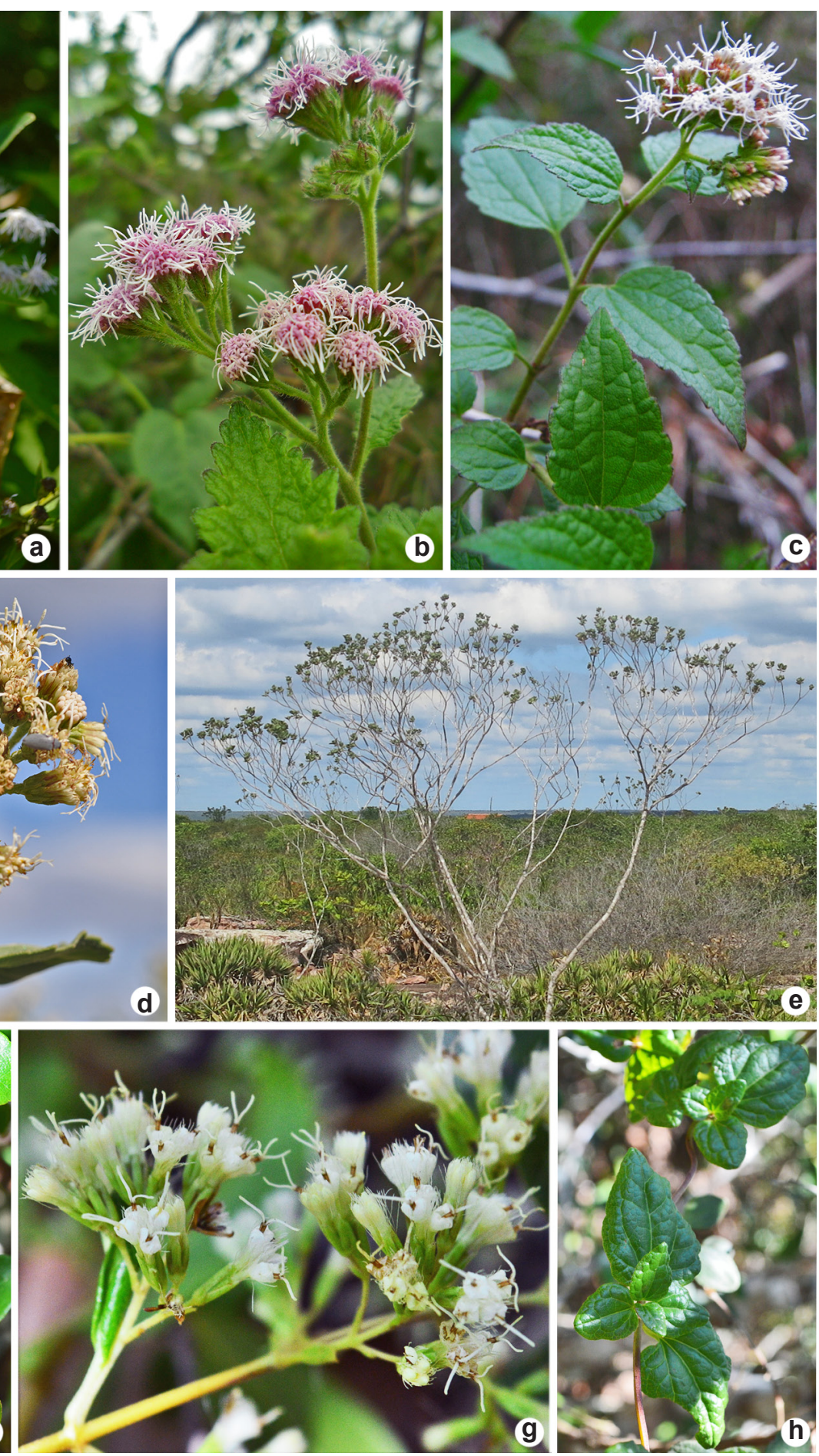

Figura 7 - a. Chromolaena maximilianii. b. Conocliniopsis prasiifolia. c. Koanophyllon conglobatum. d, e. Lapidia apicifolia. f, g. Mikania elliptica. h. Mikania grazielae. (a. A. Gandara; b, c, f, g, h. V. Amorim; d. L. Barres; e. M. Staudt).

Figure 7 - a. Chromolaena maximilianii. b. Conocliniopsis prasiifolia. c. Koanophyllon conglobatum. d, e. Lapidia apicifolia. f, g. Mikania elliptica. h. Mikania grazielae. (a. A. Gandara; b, c, f, g, h. V. Amorim; d. L. Barres; e. M. Staudt). 
multiserriado; brácteas involucrais 30-35, 5-6 séries, externas 3,2-5,1 × 1,8-2 mm, ovadas, internas 7,2-9,3 × 1,5-2mm, oblongas a lineares; ápice agudo, margem ciliada, esverdeadas com ápice castanho, glabras. Receptáculo convexo, epaleáceo. Flores 27-28, corola ca. 5,4 mm compr., lilás a alva, glabra, tubo 3-3,2 mm compr., limbo 1,7-2 mm compr., lacínias ca. 0,3 mm compr. Antera 2-2,3 mm compr., apêndice do conectivo obtuso, mais longo que largo, base arredondada, colar da antera cilíndrico. Estilete 5-6,3 mm compr., ramos do estilete lineares, ápice obtuso, glabra. Cipsela 3,7-4,5 mm compr., cilíndrica, setosa, 4-costada; carpopódio assimétrico. Pápus unisseriado, 5-5,3 mm compr., cerdoso.

Material selecionado: trilha para o Ventura, 11'40'13,4'’S, 4058'27'W, 701 m, 16.VI.2015, M.G. Staudt et al. 33 (ALCB, HUEFS).

Chromolaena maximilianii pode ser diferenciada de Chromolaena odorata (L.) R.M.King \& H.Rob. pelo porte mais robusto e ausência de tricomas glandulares sésseis na lâmina foliar (Esteves 2001). A espécie é amplamente distribuída no Brasil, em áreas de Floresta Amazônica, Mata Atlântica e Cerrado (BFG 2018). $\mathrm{Na}$ área de estudo foi coletada em borda de mata de floresta estacional semidecidual e em campo rupestre.

6.2. Chromolaena morii R.M.King \& H.Rob., Phytologia 47: 234. 1980.

Arbusto decumbente, 0,9-2,5 m alt. Ramos cilíndricos, estriados, estrigosos. Folhas opostas, pecioladas, pecíolo 2-5 mm compr.; lâmina foliar 1,9-4,8 × 0,8-1,8 cm, coriácea, concolor, ovada, ápice agudo, margem inteira, base arredondada, face adaxial glabra, face abaxial com tricomas glandulares sésseis, esparsamente pilosas nas nervuras. Capitulescência paniculiforme. Capítulos pedunculados, pedúnculo 6-7 $\mathrm{mm}$ compr. Invólucro 7-8,5 × 2,6-3 mm, cilíndrico, imbricado, multiserriado; brácteas involucrais $31-36,7-8$ séries, externas 5,2-7,1 × 0,7-1,2 mm, elípticas a lanceoladas, internas $1,2-3 \times 0,6-1,3 \mathrm{~mm}$, ovadas, ápice agudo, margem ciliada, esverdeadas com ápice vináceo, glabras. Receptáculo cônico, epaleáceo. Flores 20-22, corola 4-5 mm compr., roséa, creme a alva, tricomas glandulares sésseis, tubo ca. $1 \mathrm{~mm}$ compr., limbo ca. 3,5 mm compr., lacínias 0,3-0,5 $\mathrm{mm}$ compr., papilosas com tricomas glandulares sésseis. Antera 1,5-1,8 mm compr., apêndice do conectivo retuso a emarginado, mais longo que largo, base atenuada, colar da antera cilíndrico. Estilete ca. 4,4 mm compr., glabro, róseo, ramos do estilete lineares, ápice obtuso, papilosos. Cipsela 3-3,2 mm compr., cilíndrica, setosa nas costelas, 4-costada; carpopódio assimétrico. Pápus unisseriado, 3,2-4,1 mm compr., cerdoso.

Material selecionado: Morrão, $11^{\circ} 35^{\prime} 27,7$ 'S, 41 12 '30,5”W, 1.265 m, 17.IX.2015, M.G. Staudt et al. 120 (ALCB, HUEFS).

A espécie distingue-se de C. maximilianii pela lâmina foliar (coriácea vs. membranácea), tamanho menor do invólucro $(7-8,5 \times 2,6-3 \mathrm{~mm}$ vs. $10-12 \times 4-5 \mathrm{~mm}$ ) e pelo receptáculo (convexo vs. cônico), respectivamente. Chromolaena morii é endêmica da Bahia e ocorre nos domínios da Caatinga e Cerrado (BFG 2018). No presente estudo a espécie foi encontrada em áreas de transição de campo rupestre e cerrado.

7. Conocliniopsis R.M.King \& H.Rob.

7.1. Conocliniopsis prasiifolia (DC.) R.M.King \& H.Rob., Phytologia 23(3): 308. 1972. Fig. 7b

Arbusto, 0,3-1 m alt. Ramos cilíndricos, estriados, estrigosos. Folhas alternas, pecioladas, pecíolo 0,4-4,2 cm compr.; lâmina foliar 1-5 $\times$ 0,4-2,6 cm, membranácea, discolor, ovada, ápice agudo, margem crenada, base truncada, face adaxial estrigosa e face abaxial vilosa com tricomas glandulares sésseis. Capitulescência corimbiforme. Capítulos pedunculados, pedúnculo ca. 0,3 cm compr. Invólucro $0,6-0,5 \times 0,5-0,4$ $\mathrm{cm}$, campanulado, bisseriado; brácteas involucrais 17-20, externas 3-4 ×0,9-1,2 mm, oblanceoladas, internas 4-4,8 × 0,5-0,8mm, lanceoladas, ápice acuminado, margem inteira, esverdeadas com ápice vináceo, pubescentes. Receptáculo cônico, foveolado, epaleáceo. Flores 25-35, corola 3-3,5 mm compr., lilás, glabra, tubo 1,6-1,9 mm compr., limbo 1-1,2 mm compr., lacínias 0,3-0,4 mm compr., glabras. Antera 1,1-1,2 mm compr., apêndice do conectivo obtuso, tão longo quanto largo, base truncada, colar da antera cilíndrico. Estilete 5-4,5 mm compr., glabra, ramos do estilete lineares, ápice obtuso. Cipsela 1,2-1,6 mm compr., cilíndrica a obovóide, pilosa, 5-costada; carpopódio proeminente, anuliforme. Pápus 2,3-3 mm compr., unisseriado, cerdoso, persistente.

Material selecionado: estrada para o Ferro Doido, $11^{\circ} 37^{\prime} 40,5$ 'S, 41 00 '1,4”W, 900 m, 14.IX.2015, M.G. Staudt et al. 72 (ALCB, HUEFS).

O gênero é monoespecífico e pode ser reconhecido pela lâmina foliar ovada, margem crenada, brácteas involucrais com ápice acuminado e receptáculo cônico (King \& Robinson 1987). 
Devido a sua semelhança com Bejaranoa semistriata, C. prasiffolia pode ser facilmente diferenciada através do receptáculo cônico ( $v s$. plano) e do número de flores por capítulo 25-35 (vs. 4-5). No Brasil, Conocliniopsis prasiifolia tem registro apenas para o Nordeste (BFG 2018). Na área de estudo foi coletada principalmente em áreas antropizadas, mas também ocorre com frequência em borda de mata e nos campos rupestres.

\section{Koanophyllon Arruda}

Koanophyllon caracteriza-se pelo invólucro eximbricado ou laxamente subimbricado, receptáculo plano, corola com tubo cilíndrico, lobos curtos e com tricomas glandulares sésseis externamente e apêndice do conectivo da antera curto (King \& Robinson 1987). O gênero possui ca. 114 espécies, distribuídas desde o Paraguai até o sul dos Estados Unidos (King \& Robinson 1987). No Brasil são registradas 14 espécies, sendo que três ocorrem na Bahia e uma em Morro do Chapéu.

\subsection{Koanophyllon conglobatum (DC.) R.M.King} \& H.Rob., Phytologia 45: 465. 1980 . Fig. 7c

Arbusto ca. 0,5 m alt. Ramos cilíndricos, estriados, estrigosos. Folhas opostas, pecioladas, pecíolo 0,5-1,2 cm compr.; lâmina foliar 2,4-5,3 $\times 1,6-3,5 \mathrm{~cm}$, coriácea, levemente discolor, ovada, ápice acuminado a caudado, margem serreada a crenada, base cordada, setosa em ambas as faces, com tricomas glandulares estipitados e sésseis na face abaxial. Capitulescência glomeruliforme. Capítulos sésseis a subsésseis. Invólucro 4-5 × 2-3 $\mathrm{mm}$, subimbricado, cilíndrico, biserriado; brácteas involucrais $11-15,3-4,7 \times 0,5-1 \mathrm{~mm}$, lanceoladas, ápice agudo, margem inteira, esverdeadas, setosas. Receptáculo plano, epaleáceo. Flores 16-19, corola 3,5-4 mm compr., alva, glabra, tubo 2-2,2 mm compr., limbo 1,4-1,7 mm compr., lacínias 0,3-0,4 mm compr. Antera ca. 1,3 mm compr., apêndice do conectivo obtuso, mais longo que largo, base atenuada, colar da antera cilíndrico. Estilete 5,5-6,7 mm compr., ramos do estilete clavados, papilosos. Cipsela 1,7-2,1 mm compr., cilíndrica, setosa, 5-costada; carpopódio simétrico, anuliforme. Pápus 3,1-4 mm compr., unisseriado, cerdoso-barbelado, persistente, creme.

Material examinado: Ventura, $11^{\circ} 47^{\prime} \mathrm{S}, 40^{\circ} 57^{\prime} \mathrm{W}$, 27.VIII.1981, R.P. Orlandini 460 (HRB, RB).

Koanophyllon conglobatum diferenciase de Bejaranoa semistriata por apresentar folhas opostas (vs. alternas), capitulescência glomeruliforme (vs. corimbiforme) e flores 16-19 (vs. 4-5), respectivamente. A espécie é endêmica do Brasil, com registro no Nordeste e Sudeste (BFG 2018). Em Morro do Chapéu ocorre em áreas antropizadas e de caatinga.

\section{Lapidia Roque \& S.C.Ferreira \\ 9.1. Lapidia apicifolia Roque \& S.C.Ferreira,} Phytotaxa 291(1): 001-016. $2017 . \quad$ Fig. 7d,e

Arbusto 2-4 m alt. Ramos cilíndricos, estriados, tomentosos a glabrescentes, ramificado na parte superior; Folhas oposta-cruzadas, pecioladas, pecíolo 0,3-0,7 cm compr.; lâmina foliar 1,2-3 $\times$ 1,5-3 cm; coriácea, concolor, orbicular a obovada, ápice arredondado a truncado, dois terços da margem superior serreada, base cuneada a truncada, tricomas glandulares sésseis e estipitados nas faces adaxial e abaxial. Capitulescência corimbiforme. Capítulos pedunculados, pedúnculo 3-7 $\mathrm{mm}$ compr., tomentosos; 4 bractéolas. Invólucro 5 $\times 6 \mathrm{~mm}$, campanulado, eximbricado; brácteas involucrais 13-17, 3 séries, externas 2,3-4,1 $\times$ 0,8-1,1 mm, oblanceoladas, internas 4,5-5mm $\times 0,5-0,9 \mathrm{~mm}$, lanceoladas a lineares, ápice acuminado, margem inteira, esverdeadas com ápice castanho, tomentosas. Receptáculo plano, epaleáceo. Flores 20-23, corola 4,7-5,2 mm compr., alva, tubo 1,5-2 mm compr., limbo 1,5-1,8 $\mathrm{mm}$ compr., lacínias triangulares, 0,6-0,7 mm compr., papilosas. Antera 1,8-2,3 mm compr., apêndice do conectivo obtuso, tão longo quanto largo, base arredondada, colar da antera cilíndrico. Estilete 4,2-6,3 mm compr., ramos do estilete lineares. Cipsela 2-2,5 mm compr., cilíndrica, setosa nas costelas, 5-costada; carpopódio anuliforme. Pápus unisseriado, cerdoso, róseo a castanho.

Material selecionado: Cachoeira Ferro Doido, 11'37'40,5”S, 4100'1,4”W, 900 m, 14.IX.2015, M.G. Staudt et al. 74 (Holótipo: ALCB, isótipo: HUEFS).

De acordo com Roque et al. (2017), Lapidia é um gênero monoespecífico endêmico de Morro do Chapéu. A espécie predomina nos campos rupestres, estritamente sob afloramentos rochosos na região. Pelo hábito arbutivo de 2-4 m de altura, ramificação na parte superior, ramos tomentosos e folhas oposto-cruzadas, crassas e conduplicadas, Lapidia apicifolia é facilmente distinguida e diferenciada da vegetação local.

\section{Mikania Willd.}

O gênero é caracterizado por possuir apenas quatro brácteas involucrais, às vezes uma subinvolucral, dispostas em uma única série e quatro flores por capítulo. É o maior gênero da tribo 
Eupatorieae, com aproximadamente 400 espécies de distribuição Pantropical (Holmes 1990). No Brasil ocorrem 202 espécies e 141 são endêmicas
(BFG 2018). Com seis espécies, Mikania é o gênero com maior riqueza de espécies para a tribo em Morro do Chapéu.

\section{Chave de identificação das espécies de Mikania}

1. Cipsela $10-$ costada

10.5. Mikania grazielae

1'. Cipsela 5-costada.

2. Lâmina foliar ovada, margem denteada, discolor; cipsela glabra.

3. Lâmina foliar 2,3-4 cm compr., coriácea, base oblíqua a arredondada; capitulescência tirsoide; capítulos pedunculados 10.6. Mikania phaeoclados

3'. Lâmina foliar 5,5-13 cm compr., membranácea, base hastada; capitulescência glomeruliforme; capítulos sésseis 10.4. Mikania glomerata

2'. Lâmina foliar elíptica ou cordiforme, margem inteira ou crenulada, concolor; cipsela setosa, pilosa ou com tricomas glandulares.

4. Lâmina foliar elíptica, 5,2-10 cm compr., ápice acuminado, margem inteira, revoluta, base atenuada. 10.3. Mikania elliptica

4'. Lâmina foliar cordiforme, $1,7-5,5 \mathrm{~cm}$ compr., ápice agudo, margem crenulada sinuosa, base cordada ou hastada.

5. Ramos hexagonais; capitulescência corimbiforme 10.2. Mikania cordifolia

5'. Ramos cilíndricos; capitulescência glomeruliforme 10.1. Mikania congesta

10.1. Mikania congesta DC., Prodr. 5: 197. 1836.

Liana. Ramos cilíndricos, estriados, tomentosos. Folhas opostas, pecioladas, pecíolo 1,5-2,5 cm compr.; lâmina foliar 1,7-5,5 × 1,6-3,6 $\mathrm{cm}$, membranácea, concolor, cordiforme, ápice agudo, margem crenulada a sinuosa, base cordada, pubérula com tricomas glandulares sésseis em ambas as faces. Capitulescência glomeruliforme. Capítulos pedunculados, pedúnculo $0,4-0,7 \mathrm{~cm}$ compr., 1 bráctea subimbrical. Invólucro 2,5 $\times 2 \mathrm{~mm}$, campanulado, unisseriado; brácteas involucrais 4, 3-3,2 × 0,8-1,3 mm, ápice agudo a acuminado, margem ciliada, esverdeadas, pilosas. Receptáculo plano, epaleáceo. Flores 4, corola ca. $3 \mathrm{~mm}$ compr., alva, com tricomas glandulares sésseis, tubo 1,3-1,7 mm compr., limbo ca. $1 \mathrm{~mm}$ compr., lacínias $0,4 \mathrm{~mm}$ compr., papilosas. Antera 1,1-1,3 mm compr., apêndice do conectivo agudo, mais longo que largo, base cordada, colar da antera cilíndrico. Estilete 4,3-5 mm compr., glabro, ramos do estilete lineares, ápice obtuso, papilosos. Cipsela ca. 1,2 mm compr., prismática, tricomas glandulares sésseis, 5-costada; carpopódio inconspícuo. Pápus 3-3,4 mm compr., unisseriado, cerdoso, alvo.

Material selecionado: Morro do Chapéu, Balneário

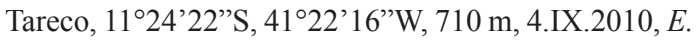
Melo et al. 8460 (HUEFS).

Mikania congesta diferencia-se de Mikania cordifolia (L.f.) Willd. pelos ramos cilíndricos e capítulos que formam um glomérulo congesto. A espécie está distribuída nas regiões Norte (Amazonas, Pará, Rondônia, Roraima), Nordeste (Alagoas, Ceará, Paraíba) e Centro-Oeste (Mato Grosso do Sul) nos domínios da Amazônia, Caatinga, Pantanal (BFG 2018). M. congesta é um novo registro para o estado da Bahia. $\mathrm{Na}$ área de estudo ocorre em áreas de campo rupestre e floresta estacional semidecidual

10.2. Mikania cordifolia (L.f.) Willd., Sp. Pl 3(3): 1746. 1803.

Liana. Ramos hexagonais, estriados, pilosos. Folhas opostas, pecioladas, pecíolo 2-2,5 cm compr.; lâmina foliar 3-4 × 1,3-2,7 $\mathrm{cm}$, membranácea, concolor, cordiforme, ápice agudo, margem sinuosa, base cordada ou hastada, face adaxial pubescente, face abaxial densamente pilosa, tricomas glandulares estipitados e sésseis em ambas as faces. Capitulescência corimbiforme. Capítulos pedunculados, pedúnculo 0,2-0,4 cm compr., Invólucro $6 \times 3 \mathrm{~mm}$, cilíndrico, unisseriado; brácteas involucrais 4,7 × 1,5 mm, ápice agudo, margem ciliada, esverdeadas, pilosas. Receptáculo plano, epaleáceo. Flores 4, corola 4,2 $\mathrm{mm}$ compr., alva, tubo ca. $2 \mathrm{~mm}$ compr., limbo ca. $1 \mathrm{~mm}$ compr., lacínias 1,2 mm compr., papilosas. Antera ca. $2 \mathrm{~mm}$ compr., apêndice do conectivo agudo, mais longo que largo, base cordada, colar 
da antera cilíndrico. Estilete 4-6 mm compr., base cilíndrica, ramos do estilete clavados. Cipsela ca. 3 mm compr., cilíndrica, pilosa a glabrescente com tricomas glandulares sésseis, 5-costada; carpopódio anuliforme, simétrico. Pápus 3-4,5 mm compr., unisseriado, cerdoso-barbelado, alvo.

Material examinado: Vila Ventura, $11^{\circ} 40^{\prime} \mathrm{S}, 41^{\circ} 01^{\prime} \mathrm{W}$, 9.XII.2006, M.L. Guedes et al. 12985 (ALCB).

A espécie diferencia-se das demais que ocorrem na área de estudo pelos ramos hexagonais e capítulos dispostos em capitulescência corimbiforme. Mikania cordifolia tem distribuição cosmopolita com registros para os Estados Unidos, América Central e América do Sul (Barroso 1958; King \& Robinson 1987). No Brasil é amplamente distribuída em todos os dominíos fitogeográficos (BFG 2018) e em Morro do Chapéu ocorre em área de caatinga.

10.3. Mikania elliptica DC., Prodr. 7(1): 270-271. 1838.

Fig. 7f,g

Liana. Ramos cilíndricos, estriados, pubérulos a glabrescentes. Folhas opostas, pecioladas, pecíolo 0,6-1,2 cm compr.; lâmina foliar 5,2-10 × 2,5-4,5 $\mathrm{cm}$, cartácea, concolor, elíptica, ápice acuminado, margem inteira a revoluta, base atenuada, tricomas glandulares sésseis na face adaxial e face abaxial pubérula a glabrescente. Capitulescência tirsoide. Capítulos pedunculados, pedúnculo $0,5-0,8$ $\mathrm{cm}$ compr., 1 bráctea subinvolucral. Invólucro 2,8-3 × 1,8-2 mm campanulado, unisseriado, eximbricado; brácteas involucrais 4, 2,8-3,3 $\times$ 0,8-1 mm, oblanceoladas, ápice obtuso, margem ciliada, pubérulas, esverdeadas. Receptáculo plano, epaleáceo. Flores 4, corola , 3-3,5 mm compr., com tricomas glandulares sésseis, creme, tubo $1-1,2$ mm compr., limbo 1,4-1,7 mm compr., lacínias 0,5-0,6 mm compr. Antera ca. 1,5 mm compr.; apêndice do conectivo obtuso a truncado, mais longo que largo, base arredondada, colar da antera trapezoide. Estilete 3,2-6,3 mm compr., glabro, ramos do estilete clavados. Cipsela 2,3-2,5mm compr., cilíndrica, setosa, 5-costada; carpopódio anuliforme. Pápus 3,2-3,8 mm compr., unisseriado, cerdoso, alvo.

Material selecionado: Poço do Homem, na ponte, 11³4'10,7'’S, 41 07'44,8'W, 948 m, 15.IX.2015, M.G. Staudt et al. 95 (ALCB, HUEFS).

A espécie pode ser reconhecida e diferenciada pelos ramos e folhas pubérulos a glabrescentes, lâmina foliar elíptica e venação reticulada. Mikania elliptica é restrita aos estados da Bahia e de Minas Gerais. Na área de estudo, os espécimes foram coletados em áreas de floresta estacional semidecidual e de campo rupestre.

10.4. Mikania glomerata Spreng., Syst. Veg. 3: 421. 1826.

Liana. Ramos cilíndricos, estriados, pubérulos, vináceos. Folhas opostas, pecioladas, pecíolo 1-4,5 cm compr.; lâmina foliar 5,5-13 $\times 2,5-7,5 \mathrm{~cm}$, membranácea, discolor, ovada, ápice agudo, margem denteada, base hastada, glabra nas faces adaxial e abaxial, pubescente nas nervuras. Capitulescência glomeruliforme. Capítulos sésseis. Invólucro $5 \times 4 \mathrm{~mm}$, unisseriado; brácteas involucrais 4 , verdes, 2-4 mm compr., oblongas, ápice obtuso, margem inteira, pubérula. Receptáculo plano, epaleáceo. Flores 4; corola ca. 5 $\mathrm{mm}$ compr, glabra, alva, tubo $2 \mathrm{~mm}$ compr., limbo $2 \mathrm{~mm}$ compr., lacínias $1 \mathrm{~mm}$ compr. Antera 3,3 mm compr., apêndice do conectivo agudo, mais longo que largo, base, colar da antera cilíndrico. Estilete ca. 8,5 mm compr., ramos do estilete lineares, ápice obtuso, base espessada, glabra. Cipsela 2,8-3,2 mm compr., cilíndrica com base atenuada, 5-costada; glabra; carpopódio simétrico, anuliforme. Pápus 4-4,7 mm compr., unisseriado, cerdoso, creme a ferrugíneo.

Material examinado: $11^{\circ} 55^{\prime} \mathrm{S}, 4^{\circ} 15^{\prime} \mathrm{W}, 24 . \mathrm{X} .2003$, M.L. Guedes et al.10797 (ALCB).

Mikania glomerata apresenta uma variação na forma das folhas, que podem ser ovaladas a lanceolado-hastadas, com 3-5 lóbulos, semelhante às de Mikania laevigata Sch.Bip. ex Baker que são ovalado-lanceoladas, sem lóbulos, e com isso, é comumente confundida com esta espécie (Ritter \& Miotto 2005). Mikania glomerata ocorre na Argentina, Brasil e Paraguai (Barroso 1958; King \& Robinson 1987). No Brasil é encontrada nas regiões Centro-Oeste, Nordeste, Sudeste e Sul nos domínios do Cerrado e da Mata Atlântica (BFG 2018). Em Morro do Chapéu a espécie tem registro em área de floresta estacional semidecidual.

10.5. Mikania grazielae R.M.King \& H.Rob., Phytologia 45: 126-127. 1980. Figs. 7h; 8a Liana. Ramos cilíndricos, estriados, pubérulos, vináceos. Folhas opostas, pecioladas, 0,5-1,4 cm compr.; lâmina foliar 2,8-5,2 × 2,5-3,5 $\mathrm{cm}$, membranácea, discolor, ovada, ápice agudo a acuminado, margem inteira, revoluta, base cordada a truncada, face adaxial glabra a esparso pubérula, face abaxial denso glandulosa, vinácea, nervação actinódroma (3 nervuras). Capitulescência corimbiforme. Capítulos pedunculados, pedúnculo 
ca. $2 \mathrm{~mm}$ compr. Invólucro 4-5 × 2,5-3 mm, cilíndrico, unisseriado; brácteas involucrais 4 , verdes, $5 \times 2,5 \mathrm{~mm}$, oblongas, ápice obtuso, margem ciliada, glabras, vináceas. Receptáculo plano, epaleáceo. Flores 4, corola ca. 6,5 mm compr., alva, tubo ca. $3 \mathrm{~mm}$ compr., limbo ca. 2 $\mathrm{mm}$ compr., lacínias ca. 1,5 mm compr. Anteras ca. 1,6 mm compr.; apêndice do conectivo ca. 0,5 mm compr., mais longo do que largo, ápice agudo, colar da antera cilíndrico. Estilete ca. $9 \mathrm{~mm}$ compr., ramos do estilete lineares, ca. 3,5 mm compr. Cipsela ca. 3,8 mm compr., 10-costada, tomentosa, principalmente na base e no ápice. Pápus ca. $6 \mathrm{~mm}$ compr., cerdoso, alvo.

Material examinado: Morrão, 14.IX.2016, 11³4”24”S, 4112'31'W, A. Gandara \& V.O. Amorim 137 (ALCB).

Mikania grazielae pode ser reconhecida pela lâmina foliar com face abaxial denso-glandulosa, capitulescência corimbiforme, cipsela 10-costada com base densamente tomentosa e pela coloração vinácea dos ramos, da face abaxial das folhas e das brácteas involucrais (Barroso 1958). M. grazielae é endêmica da Bahia, onde ocorre nos domínios fitogeográficos do Cerrado e da Caatinga (BFG 2018). Em Morro do Chapéu foi encontrada em área de transição de floresta estacional semidecidual e campo rupestre.

10.6. Mikania phaeoclados Mart. ex Baker, Fl. bras. 6(2): 256. 1876.

Liana. Ramos cilíndricos, estriados, vilosos com tricomas glandulares sésseis. Folhas opostas, pecioladas, pecíolo 0,4-0,6 cm compr.; lâmina foliar 2,3-4 × 1,7-2,9 cm, coriácea, discolor, ovada, ápice obtuso, margem denteada, revoluta, base oblíqua a arredondada, face adaxial com indumento estriguloso, face abaxial pilosa, vinácea. Capitulescência tirsóide. Capítulos pedunculados, pedúnculo ca. 0,2 mm compr. Invólucro 3-4,2 $\times$ 2,2-3 mm, cilíndrico, unisseriado; brácteas involucrais 4 , verdes, 3-4 × 1,5-4 mm, oblongas, ápice arredondado, margem ciliada, glabras, vináceas. Receptáculo plano, epaleáceo. Flores 4, corola 4,3-5 mm compr., alva, glabra, tubo $2 \mathrm{~mm}$ compr., limbo 1,5 mm compr., lacínias 0,8-1,5 mm compr. Antera $2 \mathrm{~mm}$ compr.; apêndice do conectivo obtuso, mais longo do que largo, base arredondada, colar da antera cilíndrico, base cilíndrica, glabra. Estilete 4-7 mm compr., ramos do estilete lineares, ápice obtuso. Cipsela $3 \mathrm{~mm}$ compr., cilíndrica, glabra, 5-costada; carpopódio simétrico, anuliforme. Pápus unisseriado, 5,5-6 mm compr., cerdoso, caduco, creme.
Material examinado: Morrão, 16.I.1977, G.Hatschbach 39673 (MBM, RB).

Mikania phaeoclados é muito próxima de M. grazielae, porém a última espécie apresenta cipsela 10-costada, o que a diferencia das outras espécies encontradas neste estudo. A espécie é endêmica do Brasil e ocorre em Minas Gerais, Espírito Santo e Bahia nos domínios da Caatinga, Cerrado e Mata Atlântica (BFG 2018). Em Morro do Chapéu foi encontrada em área de transição entre floresta estacional semidecidual e campo rupestre.

11. Prolobus R.M. King \& H.Rob.

11.1. Prolobus nitidulus (Baker) R.M.King \& H.Rob. Phytologia 50(5): 387. 1982.

Arbusto 0,3-1,20 m alt. Ramos cilíndricos, estriados, pilosos. Folhas alternas, pecioladas, pecíolo 0,5-0,7 mm compr.; lâmina foliar 2,8-3,7 $\times 1,1-1,6 \mathrm{~cm}$, cartácea, discolor, elíptica a ovada, ápice agudo, margem denteada e ciliada, base oblíqua, face adaxial glabra e face abaxial pilosa nas nervuras e nas margens. Capitulescência corimbiforme. Capítulos pedunculados, pedúnculo 0,5-1,2 cm compr. Invólucro 3,5-4 × 0,3-0,4 cm, cilíndrico; bisseriado; brácteas involucrais 12-17, 2 séries sub-iguais, externas 3,8-4,3 ×0,7-1 mm, internas 4-4,1 ×0,3-0,4 mm, lanceoladas, ápice agudo, margem ciliada, esverdeadas com ápice vináceo, tricomas glandulares na face abaxial. Receptáculo convexo a cônico, epaleáceo. Flores 22-27, corola 2,5-3 mm compr., lilás, papilosa, tubo 1,3-1,5 mm compr., limbo 1,1-1,3 $\mathrm{mm}$ compr., lacínias 0,2-0,3 mm compr., papilosas. Antera 1,3-1,4 mm compr., apêndice do conectivo obtuso, mais longo que largo, colar da antera cilíndrica. Estilete 4,3-4,9 mm compr., glabra, ramos do estilete lineares, ápice obtuso, lilás a alvo. Cipsela 1,3-2 mm compr., obcônica, pilosa, 5-costada; carpopódio anuliforme. Pápus unisseriado, 1,2-2,3 mm compr., cerdoso.

Material selecionado: Cachoeira Ferro Doido, 11'37'38,7'S, 41 ${ }^{\circ} 00$ '0,3”W, 902 m, 18.VI.2015, M.G. Staudt et al. 67 (HUEFS).

Prolobus é um gênero monoespecífico caracterizado pelo hábito arbustivo com projeções papilosas do interior dos lobos da corola e presença de células espessas no carpopódio (King \& Robinson 1987). Prolobus nitidulus é endêmica da Bahia e ocorre preferencialmente em vegetação de restinga no domínio Mata Atlântica (BFG 2018). Em Morro do Chapéu foi coletada em áreas de campo rupestre. 

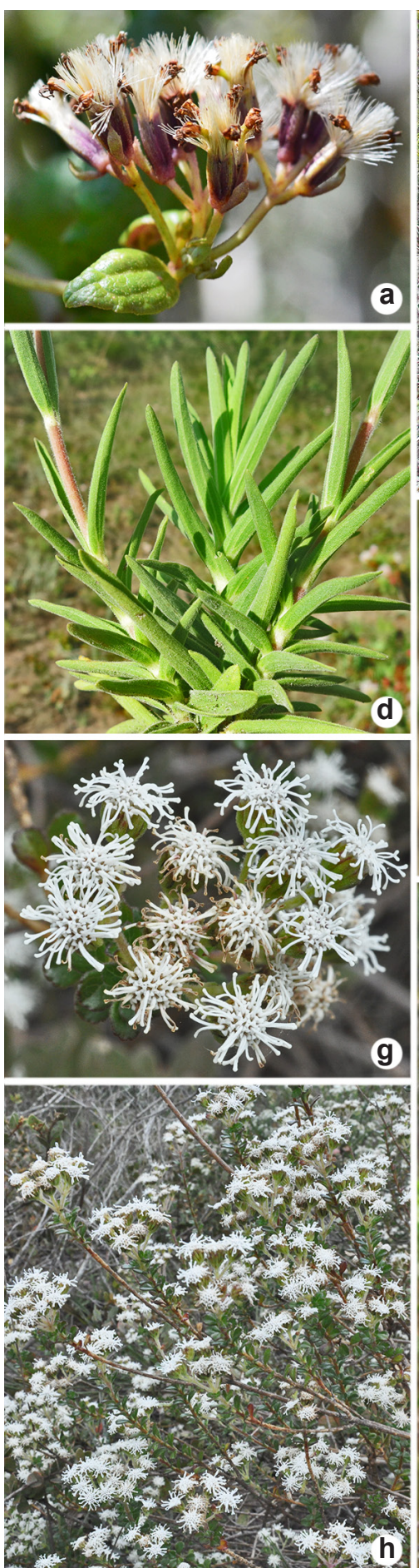
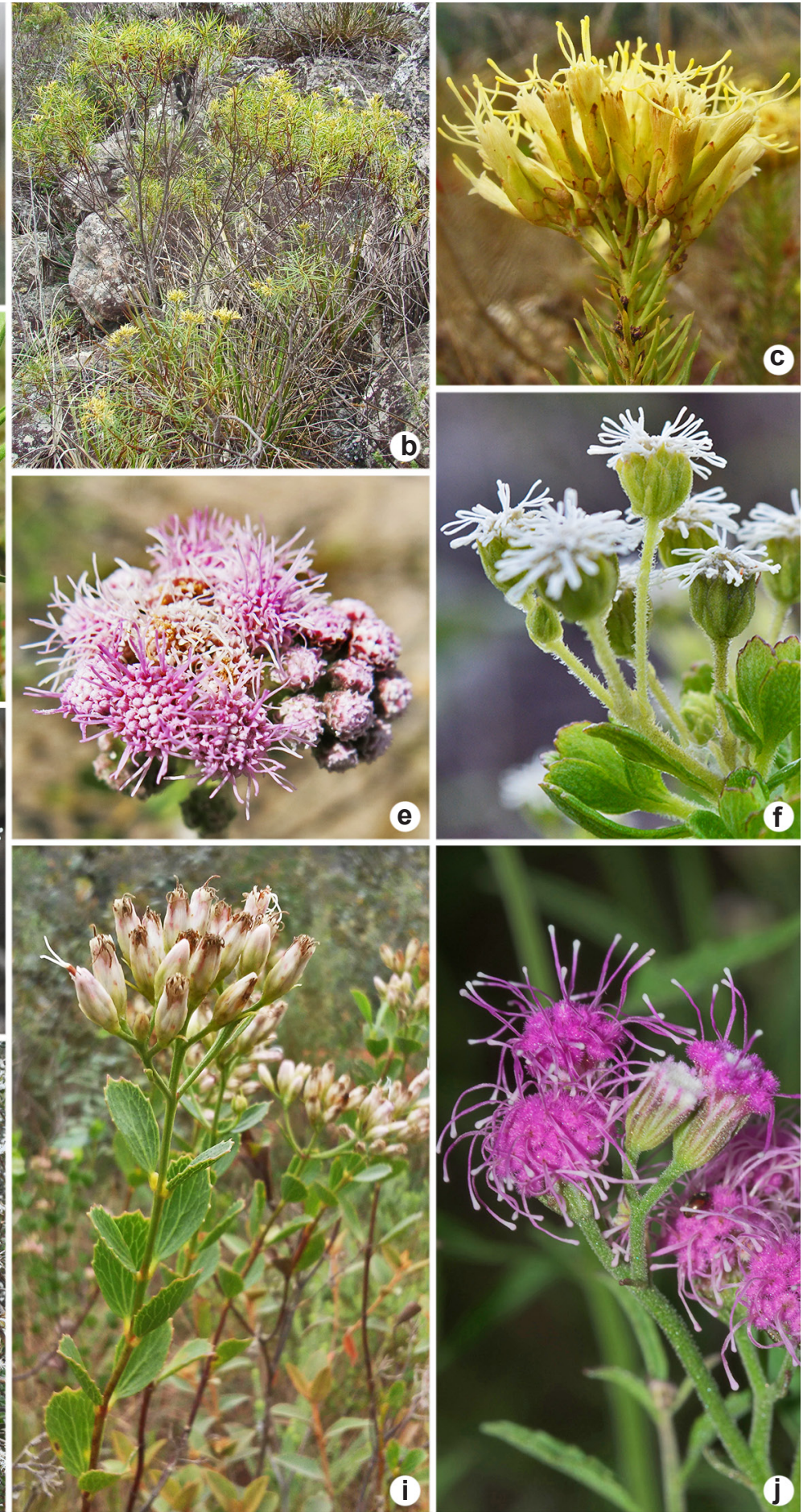

Figura 8 - a. Mikania grazielae. b, c. Pseudobrickellia brasiliensis. d, e. Scherya bahiensis. f. Stylotrichium corymbosum. g, h. Stylotrichium edmundoi. i. Symphyopappus decussatus. j. Trichogonia campestris. (a, f. A. Gandara; b, c, d, j. N. Roque; e. M. Staudt; g, h. L. Barres; i. V. Amorim).

Figure 8 - a. Mikania grazielae. b, c. Pseudobrickellia brasiliensis. d, e. Scherya bahiensis. f. Stylotrichium corymbosum. g, h. Stylotrichium edmundoi. i. Symphyopappus decussatus. j. Trichogonia campestris. (a, f. A. Gandara; b, c, d, j. N. Roque; e. M. Staudt; g, h. L. Barres; i. V. Amorim). 
12. Pseudobrickellia R.M.King \& H.Rob.

Caracteriza- se por apresentar folhas lineares e espiraladas, poucas flores por capítulo (2-4) e lobos da corola com tricomas tectores ou glandulares (King \& Robinson 1972). O gênero possui apenas duas espécies (King \& Robinson 1972, 1987), ambas endêmicas do Brasil, com ampla distribuição e ausentes apenas na Região Sul (BFG 2018). Na área de estudo foi encontrada uma espécie.

12.1. Pseudobrickellia brasiliensis (Spreng.) R.M.King \& H.Rob., Phytologia 24: 75. 1972.

Fig. 8b,c

Arbusto ca. $50 \mathrm{~cm}$ alt. Ramos cilíndricos, estriados, glabrescentes, com cicatrizes de inserção da folha. Folhas alternas, espiraladas, sésseis; lâmina foliar $1-1,5 \times 0,1-0,2 \mathrm{~cm}$, cartácea, concolor, linear, ápice agudo, margem inteira, base truncada, glabra. Capitulescência corimbiforme. Capítulos pedunculados, pedúnculo 2-3 mm compr. Invólucro cilíndrico, $5 \times 3 \mathrm{~mm}$, multisseriado; brácteas involucrais $12-14,5$ séries, externas $1,4-2 \times 0,5-1 \mathrm{~mm}$, ovadas, internas $3,6-5,1 \times 1-1,7 \mathrm{~mm}$, lanceoladas a ovadas, ápice agudo, margem ciliada, esverdeadas, glabras. Receptáculo plano, epaleáceo. Flores 3, corola 3,7-4,2 mm compr., creme, papilosa, tubo 1,4-2 mm compr., limbo 1,8-2 mm compr., lacínias 0,3-0,4 mm compr. Antera 1,8-2 $\mathrm{mm}$ compr., apêndice do conectivo obtuso a truncado, mais largo que longo, base cuneada, colar da antera cilíndrico. Estilete 3-3,3 $\mathrm{mm}$ compr., ramos do estilete clavados, papilosos. Cipsela 1,3-1,7 mm compr., cilíndrica, pilosa, 5-costada; carpopódio assimétrico. Pápus 4-4,3 mm compr., bisseriado, cerdas sub-iguais, cerdoso, creme a alvo.

Material examinado: 9.XII.2006, M.L. Guedes et al. 16279 (ALCB).

A espécie diferencia-se de Pseudobrickellia angustissima (Spreng. ex Baker) R.M.King \& H.Rob. pela lâmina foliar menor ( $v s$. 3-4 $\times 1,2-1,6 \mathrm{~cm}$ ), folhas que não ultrapassam a capitulescência e base do estilete alargada (vs. cilíndrica), respectivamente (Roque et al. 2016). Em Morro do Chapéu ocorre em área de campo rupestre.

13. Scherya R.M.King \& H.Rob.

13.1. Scherya bahiensis R.M.King \& H.Rob., Phytologia 38: 101. 1977.

Fig. 8d,e

Subarbusto decumbente, $30-50 \mathrm{~cm}$ alt. Ramos cilíndricos, estriados, tomentosos. Folhas oposta-espiraladas, sésseis; lâmina foliar 4-7 × $0,4-0,7 \mathrm{~cm}$, coriácea, concolor, linear, ápice agudo, margem ciliada, base truncada, tomentosas nas faces adaxial e abaxial. Capitulescência cimosa. Capítulos pedunculados, pedúnculo $0,2-0,4 \mathrm{~mm}$ compr.; 2 bractéolas. Invólucro $4 \times 4 \mathrm{~mm}$, campanulado, bisseriado; brácteas involucrais ca. 18 , subiguais, externas $3,2-2,3 \times 0,6-0,9 \mathrm{~mm}$, internas 3,8-4,3 $\times 0,7-1 \mathrm{~mm}$, ápice com apêndice cartáceo sinuoso, margem sinuosa, esverdeadas com ápice róseo, tomentosas. Receptáculo plano a levemente convexo, paleáceo, 14-15 páleas, lineares, ápice cartáceo sinuoso, margem inteira, 4-4,3 $\mathrm{mm}$ compr., planas, persistentes. Flores $24-25$, corola $2,5-3,1 \mathrm{~mm}$ compr., rosa a alva, papilosa, tubo $1,2-1,3 \mathrm{~mm}$ compr., limbo 1,2-1,4 mm compr., lacínias ca. 0,3 mm compr., papilosa. Antera 1,3-1,4 mm compr., apêndice do conectivo obtuso, tão longo quanto largo, base arredondada, colar da antera cilíndrica. Estilete 3,8-4,1 mm compr., glabro, ramos do estilete filiformes, ápice obtuso. Cipsela 1,7-1,9 $\mathrm{mm}$ compr., prismática, tricomas glandulares sésseis, 5-costada; carpopódio simétrico. Pápus unisseriado, 1,2-1,4 mm compr., coroniforme, irregularmente denteado.

Material selecionado: Tabuleiro do Tigre,

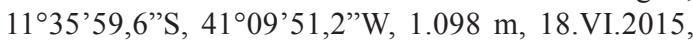
M.G. Staudt et al. 58 (ALCB, HUEFS).

Scherya é um gênero monoespecífico endêmico dos campos rupestres de Morro do Chapéu. Segundo King \& Robinson (1987), as folhas lineares oposto-cruzadas, com venação abaxial sub-paralela, presentes em Scherya bahiensis são consideradas únicas na tribo Eupatorieae. Como caracteres diagnósticos, destacam-se também as brácteas involucrais e as páleas terminadas em apêndices cartáceos sinuosos e o evidente pápus coroniforme-denteado (Roque \& Bautista 2007).

\section{Stevia Cav.}

Stevia pode ser facilmente reconhecido através dos capítulos envolvidos por cinco brácteas involucrais, cinco flores por capítulo e corola com a face densamente pubescente. É um dos maiores gêneros da tribo Eupatorieae, com cerca de 230 espécies amplamente distribuídas nas Américas (King \& Robinson 1987). Ocorrem 35 espécies no Brasil, sendo 23 endêmicas (BFG 2018). Na Bahia são registradas duas espécies e na área de estudo uma. 
14.1. Stevia morii R.M.King \& H.Rob., Phytologia 46(5): 299. 1980.

Arbusto ca. $80 \mathrm{~cm}$ alt. Ramos cilíndricos, pilosos com tricomas glandulares estipitados. Folhas opostas, pecioladas, pecíolo $0,4-0,8$ $\mathrm{cm}$ compr.; lâmina foliar $2-3,8 \times 0,5-2 \mathrm{~cm}$, membranácea, discolor, forma elíptica a ovada, ápice agudo, margem crenada, base atenuada, pilosa, face adaxial com tricomas glandulares estipitados e face abaxial com tricomas glandulares sésseis. Capitulescência terminal. Capítulos pedunculados, pedúnculo $1-1,5 \mathrm{~cm}$ compr. Invólucro $0,6-0,7 \times 0,3-0,4 \mathrm{~cm}$, cilíndrico, unisseriado; brácteas involucrais 5 , verdes, $5,2-7 \times$ 0,7-1,8 mm, oblanceoladas, ápice agudo, margem inteira, tricomas glandulares estipitados na face adaxial. Receptáculo plano, epaleáceo. Flores 5, corola ca. $7 \mathrm{~mm}$ compr., lilás a alva, pubescente, tubo ca. $1 \mathrm{~mm}$ compr., limbo ca. $4 \mathrm{~mm}$ compr., lacínias triangulares ca. $2 \mathrm{~mm}$ compr., papilosas. Antera 2,3-2,5 mm compr., apêndice do conectivo $0,6-0,8 \mathrm{~mm}$ compr., mais longo que largo, base arredondada, colar da antera cilíndrico. Estilete 5-6,8 mm compr., glabra, ramos do estilete $3 \mathrm{~mm}$ compr., ramos lineares, ápice obtuso, papilosos.
Cipsela 4,2-4,5 mm compr., cilíndrica a cuneada, setosa, 5-costada; carpopódio assimétrico. Pápus 5-6 mm compr., unisseriado, simples, cerdosobarbelado.

Material examinado: $11^{\circ} 35^{\prime} 31^{\prime \prime} \mathrm{S}, 41^{\circ} 13^{\prime} 50^{\prime \prime} \mathrm{W}$, 27.VIII.1980, H.P. Bautista 405 (HRB, RB).

Dentre as espécies de pápus paleáceo e aristado, Stevia morii diferencia-se pela lâmina foliar ovada, margem crenada e base atenuada (King \& Robinson 1980a). A espécie é considerada restrita para a Cadeia do Espinhaço em áreas de Cerrado e campo rupestre (BFG 2018). Com apenas um registro de coleta em Morro do Chapéu, a espécie ocorre em campo rupestre.

\section{Stylotrichium Mattf.}

Stylotrichium pode ser distinguido dos demais gêneros de Eupatorieae pelo receptáculo cônico e paleáceo, estilete pubescente abaixo do ponto de bifurcação, pápus reduzido ou ausente e corola alva (King \& Robinson 1980b, 1987). O gênero é endêmico dos campos rupestres da Chapada Diamantina e compreende seis espécies (Amorim \& Roque 2017). Em Morro do Chapéu são registradas duas espécies.

\section{Chave de identificação das espécies de Stylotrichium}

1. Folha séssil a subpeciolada (pecíolo $0,2 \mathrm{~cm}$ compr.), lâmina foliar $0,8-1,5 \mathrm{~cm}$ compr.

15.1. Stylotrichium corymbosum

1'. Folha peciolada (pecíolo 1,3-1,5 cm compr.), lâmina foliar 0,4-0,5 cm compr.

15.2. Stylotrichium edmundoi

15.1. Stylotrichium corymbosum (DC.) Mattf., Notizbl. Bot. Gart. Berlin-Dahlem 8: 437. 1923.

Fig. $8 \mathrm{f}$

Arbusto ca. $1 \mathrm{~m}$ alt. Ramos cilíndricos, estriados, tricomas glandulares sésseis. Folhas alternas, sésseis a curto-pecioladas, pecíolo ca. 0,2 cm compr.; lâmina foliar $0,8-1,5 \times 0,3-0,5 \mathrm{~cm}$, coriácea, concolor, obovada, ápice arredondado a truncado, margem crenada, revoluta, base atenuada, face adaxial com tricomas glandulares sésseis e tricomas tectores esparsos, face abaxial tomentosa com tricomas glandulares sésseis. Capitulescência umbeliforme. Capítulos pedunculados, pedúnculo ca. 0,5 cm compr. Invólucro 4,5-6 × 5-6 mm, campanulado, bisseriado; brácteas involucrais 10-13, esverdeadas, externas $2,4 \times 0,3 \mathrm{~mm}$, internas $4,2 \times 1 \mathrm{~mm}$, lanceoladas, ápice agudo, margem inteira, face adaxial tomentosa, face abaxial glabra a glabrescente, ambas com tricomas glandulares sésseis. Receptáculo cônico, paleáceo, páleas 1-2, 3-4 ×0,2 mm, lineares, ápice agudo, margem inteira, glabra, plana, persistente. Flores ca. 15 , corola ca. $2,2 \mathrm{~mm}$ compr., creme a alva com tricomas glandulares sésseis, tubo ca. $1 \mathrm{~mm}$ compr., limbo ca. $1 \mathrm{~mm}$ compr., lacínias ca. 0,2 mm compr. Antera ca. $1 \mathrm{~mm}$ compr., apêndice do conectivo obtuso, mais largo que longo, colar da antera cilíndrico. Estilete 4-5 mm compr., piloso abaixo da bifurcação, ramos do estilete clavados. Cipsela 2-2,5 mm compr., prismática, setosa nas costelas, tricomas glandulares sésseis em toda a superfície; 5-costada; carpopódio anuliforme. Pápus ca. 0,7 mm compr., unisseriado, sub-paleáceo.

Material examinado: Fazenda Pé de Serra, estrada para Bonito, $11^{\circ} 34^{\prime} 17^{\prime}$ 'S, $41^{\circ} 09^{\prime} 47^{\prime \prime}$ W, 7.IX.2006, J.L. Ferreira et al. 43 (HUEFS). 
Stylotrichium corymbosum é morfologicamente similar a Stylotrichium hortensiae V.Amorim \& Roque, porém as espécies apresentam diferenças na lâmina foliar $0,8-1,5 \times 0,3-0,5 \mathrm{~cm}(v s .3 .5-8 \times 1-3 \mathrm{~cm})$, no número de páleas do receptáculo 1-2 (vs. 3-4) e de flores no capítulo 15-25 (vs. 35-45) (Amorim \& Roque 2017). A espécie é endêmica da Chapada Diamantina e em Morro do Chapéu ocorre em área de transição entre cerrado e campo rupestre.

15.2. Stylotrichium edmundoi G.M.Barroso, Arch. Jard. Bot. Rio de Janeiro 15: 24. 1957. Fig. 8g,h

Arbusto 0,3-1,2 m alt. Ramos cilíndricos, estriados, estrigosos. Folhas alternas, pecioladas, pecíolo $1,3-1,5 \mathrm{~cm}$ compr.; lâmina foliar $0,4-0,5$ $\times 0,3-0,4 \mathrm{~cm}$, cartácea, concolor, obovada, ápice truncado, margem inteira, crenada no ápice, revoluta, base atenuada, face adaxial glabra, abaxial tomentosa. Capitulescência umbeliforme. Capítulos pedunculados, pedúnculo 0,7-1 mm compr. Invólucro 6-6,5 × 5-5,5 mm, campanulado, bisseriado; brácteas involucrais 13-16, externas 6-5m $\times 0,8-1 \mathrm{~mm}$, lanceoladas; internas 5-4 × 0,5-0,6mm, oblanceoladas, ápice agudo, margem levemente crenada, esverdeadas, face adaxial com tricomas glandulares sésseis, face abaxial estrigosa. Receptáculo cônico, paleáceo, páleas 1-2, 3-4 × 0,2 $\mathrm{mm}$, linear, ápice agudo, margem inteira, glabra, plana, persistente. Flores 20-22, corola tubulosa, $2,8 \mathrm{~mm}$ compr., alva, papilosa com tricomas glandulares sésseis, tubo 1-1,3 mm compr., limbo $1 \mathrm{~mm}$ compr., lacínias com lobos triangulares, 0,3-0,4 $\mathrm{mm}$ compr.; Antera ca. $1 \mathrm{~mm}$ compr., apêndice do conectivo da antera retuso, mais largo que longo, colar da antera cilíndrico. Estilete 5-5,2 $\mathrm{mm}$ compr., piloso abaixo do ponto de bifurcação, ramos do estilete clavados, papilosos. Cipsela 2,6-2,8 mm compr., prismática, estrigosa nas costelas com tricomas glandulares sésseis em toda a superfície, 4-5-costada; carpopódio anuliforme. Pápus 0,9-1,1 mm compr., unisseriado, sub-paleáceo.

Material selecionado: Tabuleiro do Tigre, $11^{\circ} 35$ '59,6”'S, 41 ${ }^{\circ} 09^{\prime} 52,3$ W, 1.102 m, 15.IX.2015, M. G. Staudt et al. 87 (ALCB, HUEFS).

Segundo Amorim \& Roque (2017), além das folhas pecioladas ( $v s$. sésseis a curtopecioladas), $S$. edmundoi diferencia-se de $S$. corymbosum pela venação reticulodroma basal (vs. venação reticulodroma suprabasal). S. edmundoi é endêmica de Morro do Chapéu e ocorre em áreade campo rupestre.

\section{Symphyopappus Turcz.}

Symphyopappus caracteriza-se por possuir folhas viscosas, cinco flores por capítulo e pápus bisseriado (King \& Robinson 1987; Hattori 2013). $O$ gênero apresenta 13 espécies descritas, sendo 12 endêmicas do Brasil e distribuídas na Caatinga, no Cerrado e na Mata Atlântica (BFG 2018). $\mathrm{Na}$ Bahia ocorrem quatro espécies e na área de estudo uma.

16.1. Symphyopappus decussatus Turcz., Bull. Soc. Imp. Naturalistes Moscou 21: 584. 1848.

Fig. 8 i

Arbusto ca. $50 \mathrm{~cm}$ alt. Ramos cilíndricos, estriados, vernicosos com tricomas glandulares sésseis. Folhas oposta-cruzadas, pecioladas, pecíolo 2-3 mm compr.; lâmina foliar 2,6-4 × 1,7-3,4 cm, cartácea, viscosa, discolor, ovada a orbicular, ápice agudo, margem denteada, base atenuada, face adaxial glabra, face adaxial pubérula. Capitulescência corimbiforme. Capítulos pedunculados, pedúnculo $1-1,5 \mathrm{~mm}$ compr. Invólucro $0,8-0,9 \times 0,3-0,7 \mathrm{~cm}$, cilíndrico; brácteas involucrais $17-20,5$ séries, decíduas, externas $3 \times 1,7 \mathrm{~mm}$, internas $7 \times 3 \mathrm{~mm}$, ovadas a oblanceoladas, ápice agudo a obtuso, margem ciliada, esverdeadas, pubérulas. Receptáculo plano a levemente convexo, alveolado, epaleáceo. Flores 5, corola cilíncrica, 4,6-5 $\mathrm{mm}$ compr., alva, glabra, tubo ca. 2,4 mm compr., limbo ca. 1,7 mm compr., lacínias lanceoladas, 0,8-0,9 $\mathrm{mm}$ compr., tricomas glandulares sésseis. Antera 2,3 mm compr., apêndice do conectivo agudo, mais longo que largo, base arredondada, colar da antera cilíndrico. Estilete 3-3,3 mm compr., base cilíndrica, ramos do estilete lineares, ápice obtuso, papilosos. Cipsela 3-3,2 mm compr., obcônica, com tricomas vesiculares, 5-costada; carpopódio inconspícuo. Pápus bisseriado, sub-iguais, ca. 3-5 mm compr., cerdoso-barbelado.

Material examinado: próximo à estrada para Utinga,

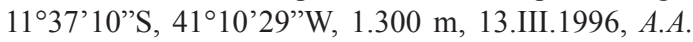
Conceição et al. 2434 (ALCB, CEPEC).

Symphyopappus decussatus é distinta das outras espécies pertencentes ao gênero pela lâmina foliar amplamente ovada a orbicular, margem denteada e brácteas involucrais decíduas (King \& Robinson 1987). Symphyopappus decussatus ocorre nos estados da Bahia e Minas Gerais em campos rupestres e cerrados, em solos arenosos ou sob afloramentos rochosos. $\mathrm{Na}$ área de estudo foi coletada em floresta estacional semidecidual. 


\section{Trichogonia Gardner}

O gênero é definido por possuir caule fortemente estriado, densa pubescência no limbo e nos lobos da corola e pápus plumoso. É um gênero sul americano com 20 espécies, das quais 17 ocorrem no Brasil e 11 na Bahia (Roque et al. 2012; BFG 2018). Na área de estudo foram encontradas três espécies.

\section{Chave de identificação das espécies de Trichogonia}

1. Folhas laxas; lâmina foliar estreito-elíptica, oblanceolada, lanceolada ou triangular, $0,4-3 \mathrm{~cm}$ larg.

2. Lâmina foliar $0,8-1,7 \times 0,4-0,7 \mathrm{~cm}$, estreito-elíptica ou oblanceolada, base atenuada.

17.1. Trichogonia campestris

2'. Lâmina foliar 2,5-7 × 1-3 cm, lanceolada ou triangular, base truncada.

17.2. Trichogonia salviifolia

1'. Folhas fasciculadas e congestas; lâmina foliar obovada, $0,1-0,2 \mathrm{~cm}$ larg.

17.3. Trichogonia tombadorensis

17.1. Trichogonia campestris Gardner, London J. Bot. 5: 459. 1846.

Fig. $8 \mathrm{j}$

Subarbusto $50-70 \mathrm{~cm}$ alt. Ramos cilíndricos, estriados, tomentosos com tricomas glandulares estipitados e sésseis. Folhas alternas, espiraladas, podendo ser conduplicadas; pecioladas, pecíolo $0,4-0,9$ cm compr.; lâmina foliar $0,8-1,7 \times 0,4-0,7$ $\mathrm{cm}$, cartácea, concolor, lanceolada a elíptica, ápice obtuso a agudo, margem crenada, base atenuada, tomentosas com tricomas glandulares sésseis. Capitulescência corimbiforme. Capítulos pedunculados, pedúnculo $0,4-1,2 \mathrm{~cm}$ compr. Invólucro $0,6-0,8 \times 0,5-0,8 \mathrm{~cm}$, campanulado, bisseriado; brácteas involucrais $13-15$, externas oblanceoladas, $4-5 \times 1-1,2 \mathrm{~mm}$, internas lineares, 5-6 × 0,4-0,7 $\mathrm{mm}$, ápice obtuso a agudo, margem inteira a ciliada, esverdeadas com ápice vináceo, tomentosas no ápice; Receptáculo plano, epaleáceo. Flores ca. 35, corola 4,5 mm compr., rosa a roxa, papilosa, com tricomas glandulares sésseis, tubo ca. 2,5 $\mathrm{mm}$ compr., limbo ca. 1,5 $\mathrm{mm}$ compr., lacínias triangulares, $0,3-0,5 \mathrm{~mm}$ compr., densamente pubescentes. Antera ca. 1,4 mm compr., apêndice do conectivo retuso, mais largo que longo, colar da antera cilíndrico. Estilete 3,5-8 mm compr., róseo, glabro, ramos do estilete lineares, ápice obtuso, alvo. Cipsela 2,5-3 mm compr., estipitada, pilosa, 5-costada; carpopódio anuliforme. Pápus ca. $3 \mathrm{~mm}$ compr., unisseriado, plumoso.

Material selecionado: Tabuleiro do Tigre, $11^{\circ} 35^{\prime} 58,8^{\prime \prime} \mathrm{S}$, 41 ${ }^{\circ} 09^{\prime} 51,4$ 'W, 1.095 m, 18.III.2016, M.G. Staudt et al. 138 (ALCB, HUEFS).

Trichogonia campestris destaca-se entre as outras espécies do gênero por apresentar folhas pecioladas, lâmina foliar estreito-elíptica a oblanceolada, base atenuada e capítulos com 30-40 flores (Roque et al. 2012). A espécie é endêmica do Brasil com registro para as regiões Norte e Nordeste nos domínios do Cerrado e da Caatinga (BFG 2018). Em Morro do Chapéu, $T$. campestris é comumente encontrada nos campos rupestres e em áreas antropizadas.

17.2. Trichogonia salviifolia Gardner, London J. Bot. 5: 460. 1846. Fig. 9a

Subarbusto $0,5-1,2 \mathrm{~m}$ alt. Ramos cilíndricos, estriados com tricomas estipitados e sésseis. Folhas alternas; pecioladas, pecíolo 1,3-2,9 cm compr.; lâmina foliar $2,5-7 \times 1-3 \mathrm{~cm}$, cartácea, levemente discolor, lanceolada, ápice agudo, margem crenada, base truncada, ambas as faces pubescentes com tricomas glandulares sésseis. Capitulescência corimbiforme. Capítulos pedunculados, pedúnculo $0,3-0,6 \mathrm{~cm}$ compr. Invólucro 6-8 × 7-8 $\mathrm{mm}$, campanulado, bisseriado; brácteas involucrais 11-13, externas $4,5-5 \times 0,8-1 \mathrm{~mm}$, lanceoladas, internas 4,8-5 $\times 0,4-0,5 \mathrm{~mm}$, oblanceoladas, ápice acuminado, esverdeadas com ápice vináceo, tomentosas no ápice. Receptáculo plano, epaleáceo. Flores 21-33, corola 3-3,8 mm compr., rosa a lilás podendo ser alva, papilosa, tubo $2-2,4 \mathrm{~mm}$ compr., limbo $0,8-1,2 \mathrm{~mm}$ compr., lacínias $0,3-0,4 \mathrm{~mm}$ compr., densamente pubescentes com tricomas glandulares sésseis. Antera 1,1-1,3 mm compr., apêndice do conectivo obtuso a retuso, tão longo quanto largo, colar da antera cilíndrico. Estilete 6-5,5 $\mathrm{mm}$ compr., ramos do estilete lineares, obtusos. Cipsela 0,2-0,3 cm compr., estipitada, pilosa, 5-costada; carpopódio anuliforme. Pápus ca. 3,3 mm compr., unisseriado, plumoso. 
Material selecionado: Barragem do Angelim, direção para o Ventura, 11'39'24"S, 40॰57'10,7'W, $704 \mathrm{~m}$, 16.VI.2015, M.G. Staudt et al. 21/22/23/24 (ALCB, HUEFS).

Segundo Roque et al. (2012), a espécie pode ser dintinguida de outras do gênero Trichogonia por suas folhas longo pecioladas $(1,3-2,9 \mathrm{~cm})$, triangulares com base truncada e número de flores por capítulo (21-33). Trichogonia salviifolia é a espécie com maior distribuição do gênero, com ocorrência na Venezuela, Colombia, Paraguai, Bolívia e no Brasil é registrada para áreas de Cerrado, Caatinga, campo rupestres, margens de floresta ripária e ambientes antropizados (Roque et al. 2012). Em Morro do Chapéu foi encontrada abundantemente em diferentes fitofisionomias da região.

18.3. Trichogonia tombadorensis R.M.King \& H.Rob., Phytologia 45: 111. 1980 . Fig. 9b,c

Subarbusto 0,2-1 $\mathrm{m}$ alt. Ramos cilíndricos, estriados, tomentosos com tricomas glandulares sésseis. Folhas alternas, fasciculadas, congestas; pecioladas, pecíolo 3-4 mm compr.; lâmina foliar 2-3,3 × 1,3-2 cm, sub-coriácea, concolor, obovada, ápice obtuso, margem inteira a serrulada, base atenuada, tricomas glandulares sésseis em ambas as faces. Capitulescência corimbiforme. Capítulos pedunculados, pedúnculo $1-2 \mathrm{~cm}$ compr. Invólucro 0,6-0,7 × 0,5-0,8 cm, bisseriado, campanulado; brácteas involucrais $12-18$, externas: 4-6 × 1-2,3 $\mathrm{mm}$, oblanceoladas; internas 5-6 × 0,7-1,2 mm, lanceoladas, ápice acuminado, margem inteira, esverdeadas com ápice rosa, serícea no ápice. Receptáculo convexo, epaleáceo. Flores 48-61, corola 3,5-4,8 $\mathrm{mm}$ compr., rosa, papilosa, tubo 1,8-2,7 mm compr., limbo 1,3-1,5 mm compr., lacínias 0,3-0,4 mm compr., densamente pubescente. Antera 1,3-1,8 mm compr., apêndice do conectivo retuso, mais largo que longo, base arredondada, colar da antera cilíndrico. Estilete 5,5-6 mm compr., glabro, ramos do estilete lineares, ápice obtuso. Cipsela 3-3,5 mm compr., estipitada, 5-costada; carpopódio inconspícuo. Pápus 2,5-3 mm compr., unisseriado, plumoso.

Material selecionado: Tabuleiro do Tigre, $11^{\circ} 35^{\prime}$ '59,6"S, $41^{\circ} 09^{\prime} 52,3$ 'W, 1.102 m, 15.IX.2015, M.G. Staudt et al. 89 (ALCB, HUEFS).

Trichogonia tombadorensis é similar a Trichogonia harleyi R.M.King \& H.Rob., pois ambas possuem folhas pequenas, fasciculadas e congestas. No entanto, T. tombadorensis pode ser diferenciada de $T$. harleyi pela lâmina foliar obovada ( $v s$. orbicular), margem inteira a serrulada
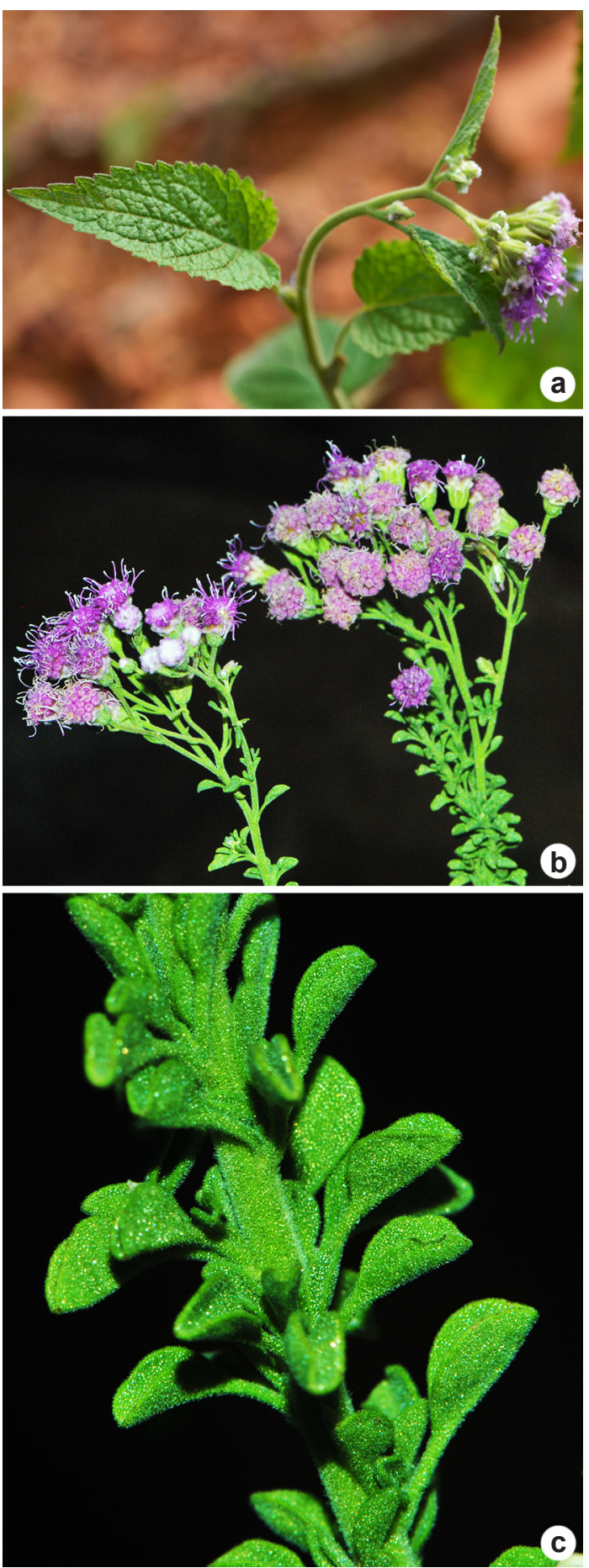

Figura 9-a. Trichogonia salviifolia. b, c. Trichogonia tombadorensis. (A. Gandara; b, c. D. Cardoso).

Figure 9 - a. Trichogonia salviifolia. b, c. Trichogonia tombadorensis. (A. Gandara; b, c. D. Cardoso). 
(vs. crenada) e base atenuada (vs. arredondada), respectivamente (Roque et al. 2012). A espécie é endêmica de Morro Chapéu, restrita aos campos rupestres da região.

\section{Material suplementar}

Este artigo possui material examinado suplementar em formato digital. Os dados podem ser acessados por meio do link < https://doi. org/10.6084/m9.figshare.11594181.v1>.

\section{Agradecimentos}

As autoras agradecem ao Ir. Delmar Alvim e à Companhia de Pesquisa de Recursos Minerais - CPRM, o apoio durante as viagens de campo; a Lídia Campos, o mapa; ao CNPq, a bolsa de Mestrado concedida à primeira autora e bolsa de Pesquisa à NR (NR-3051139/2016-9). Este trabalho teve apoio financeiro do projeto PRONEM (PNE 1642/2011).

\section{Referências}

Almeida GSS (2008) Asteraceae Dumort. nos campos rupestres do Parque Estadual do Itacolomi, Minas Gerais, Brasil. Tese de Doutorado. Universidade Federal de Viçosa, Viçosa. 365p.

Amorim VO \& Roque N (2017) Stylotrichium hortensiae (Asteraceae - Eupatorieae): a new species from Chapada Diamantina, Bahia, Brazil. Phytotaxa 308: 283-288.

Baker JG (1873) Compositae-Vernoniaceae. In: von Martiuns CFP, Eichler AW \& Urban I (eds.) Flora brasiliensis. Fried Fleischer, Munchen, Wien, Leipzig. Vol. 6, pars 2, pp. 99-137.

Barroso GM (1958) Mikaniae do Brasil. Arquivos do Jardim Botânico do Rio de Janeiro 16: 239-333.

Barroso GM (1965) De Compositarum Novitatibus. Sellowia 17: 79-84.

Bautista HP (2000) Sistemática e filogenia de um gênero endêmico do Brasil: Acritopappus R.M.King \& H.Rob. (Asteraceae, Eupatorieae). Tese de Doutorado. Universidade de Santiago de Compostela, Santiago de Compostela. 315p.

Bautista HP, Rodrigues-Oubinã J \& Ortiz S (2017) Two new species of the Brazilian endemic genus Acritopappus (Compositae, Eupatorieae) from Chapada Diamantina, Bahia state. Phytotaxa 311: 22-28.

Beentje H (2010) The Kew plant glossary: an illustrated dictionary of plant terms. Royal Botanical Garden, Kew, London. 164p.

BFG - The Brazil Flora Group (2018) Brazilian Flora 2020: innovation and collaboration to meet Target 1 of the Global Strategy for Plant Conservation (GSPC). Rodriguésia 69: 1513-1527
Bremer K (1994) Asteraceae: cladistics and classification. Timber Press, Portland. 752p.

Campos L, Guedes MLS, Acevedo-Rodrigues P \& Roque N (2016) Contributions to the floristic and vegetation knowledge of Espinhaço Septentrional, Bahia, Brazil. Brazilian Journal of Botany 40: 427-437.

CPRM - Companhia de Pesquisas de Recursos Minerais (2010) Serviço Geológico do Brasil. Shapefile de geodiversidade dos estados da Bahia e Minas Gerais. Disponivel em $<$ http://www.cprm.gov.br/publique/ Gestao-Territorial/Geodiversidade-162>. Acesso em 25 julho 2018.

Esteves RL (1993) Contribuição ao conhecimento das espécies brasileiras do gênero Stilpnopappus Mart ex DC (Compositae-Vernonieae), Seção Stilpnopappus. Dissertação de Mestrado. Universidade Federal do Rio de Janeiro, Rio de Janeiro. 137p.

Esteves RL (2001) O gênero Eupatorium s.l. (Compositae - Eupatorieae) no estado de São Paulo, Brasil. Tese de Doutorado. Universidade Estadual de Campinas, Campinas. 314p.

ESRI - Environmental Systems Research Institute (2010) ArcGIS Release 10, Redlands.

França F \& Melo E (2013) A complexidade da vegetação. In: França F, Melo E, Souza I \& Pugliesi L (orgs.) Flora de Morro do Chapéu. Vol. 1. Empresa Gráfica da Bahia, Feira de Santana. Pp. 17-19.

Funk, V. A.; Berry, P.E.; Alexander, S.; Hollowell, T.H. \& Kelloff, C.L. 2007. Checklist of the plants of the Guiana Shield (Venezuela: Amazonas, Bolivar, Delta Amacuro; Guyana, Surinam, French Guiana). Contributions from the United States National Herbarium 55: 1-584.

Funk VA, Susanna A, Stuessy TF \& Robinson H (2009) Classification of Compositae. In: Funk VA, Susanna A, Stuessy TF \& Bayer RJ (eds.) Systematics, evolution and biogeography of the Compositae. IAPT, Vienna. Pp. 171-189.

Giulietti AM, Menezes NL, Pirani JR, Meguro M \& Wanderley MGL (1987) Flora da Serra do Cipó, Minas Gerais: caracterização e lista das espécies. Boletim de Botânica da Universidade de São Paulo 9: 1-151.

Grokoviski L (2007) Estudo taxônomico do gênero Piptocarpha R.Br. (Asteraceae: Vernonieae) no estado do Paraná, Brasil. Dissertação de Mestrado. Universidade Federal do Paraná, Curitiba. 93p.

Guedes MLS \& Orge MDR (1998) Checklist das espécies vasculares do Morro do Pai Inácio (Palmeiras) e Serra da Chapadinha (Lençóis), Chapada Diamantina, Bahia, Brasil. Instituto de Biologia - UFBA, Salvador. 67p.

Guimarães JT, Alkmim FF \& Cruz SCP (2012) Supergrupos Espinhaço e São Francisco. In: Barbosa JSF (coord.) Geologia da Bahia. Pesquisa e atualização. Série Publicações Especiais, 13. CBPA, Salvador. Pp. 33-85. 
Harley RM \& Simmons NA (1986) Florula of Mucugê Chapada Diamantina, Bahia, Brazil. Royal Botanic Gardens, Kew. 228p.

Harley RM (1995) Introdução. In: Stannard BL (ed.) Flora of the Pico das Almas - Chapada Diamantina, Bahia, Brazil. Royal Botanic Gardens, Kew. Pp. 43-78.

Harris JG \& Harris MW (2001) Plant identification terminology: an illustrated glossary. $2^{\text {nd }}$ ed. Spring Lake, Utah. 206p.

Hatschbach G, Guarçoni EAE, Sartori MA \& Ribas OS (2006) Aspectos fisionômicos da vegetação da Serra do Cabral - Minas Gerais - Brasil. Boletim do Museu Botânico Municipal 67: 1-33.

Hattori EKO (2013) Revisão taxonômica e biogeografia de Symphyopappus e a sua relação dentro da subtribe Disynaphiinae. Tese de Doutorado. Universidade Federal de Minas Gerais, Belo Horizonte. 192p

Hind DJN (1993) Notes on the Compositae of Bahia, Brazil. Kew Bulletin 48: 245-277.

Hind DJN (1995) Compositae. In: Stannard BL (ed.) Flora do Pico das Almas - Chapada Diamantina, Bahia, Brasil. Royal Botanic Gardens, Kew, Londres. Pp. 175-278.

Hind DJN (2000a) Two new species of Paralychnophora (Compositae: Vernonieae) from Bahia, Brazil. Kew Bulletin 55: 367-379.

Hind DJN (2000b) A new genus, Catolesia (Compositae: Eupatorieae), and a discussion of its affinities within the subtribe Gyptidinae of Bahia, Brazil. Kew Bulletin 55: 941-948.

Hind DJN \& Robinson H (2007) Tribe Eupatorieae. In: Kadereit JW \& Jeffrey C (eds.) The families and genera of vascular plants. Flowering plants Eudicots, Asterales. Vol 8. Springer, Berlin. Pp 510-588.

Hind DJN \& Miranda EB (2008) Lista preliminar da família Compositae na Região Nordeste do Brasil. Royal Botanic Gardens, Kew. Pp. 8-16.

Hind DJN (2009) Agrianthus carvalhoi (Compositae: Eupatorieae: Gyptidinae), a new species from Bahia state, Brazil. Kew Bulletin 64: 291-294.

Holmes WC (1990) The genus Mikania (Compositae Eupatorieae) in Mexico. Sida 5: 1-4.

IBGE - Instituto Brasileiro de Geografia e Estatística (2004) Mapa de biomas e de vegetação do Brasil. Disponível em <http://www.ibge.gov.br/home/ presidencia/noticias/21052004biomashtml.shtm $>$. Acesso em 25 julho 2018.

IBGE - Instituto Brasileiro de Geografia e Estatística (2007) Divisão política do Brasil por unidades da federação. Disponível em <https://ww2.ibge.gov. br/home/geociencias/cartografia/default_dtb_int. shth>. Acesso em 25 julho 2018.

Keeley SC \& Robinson H (2009) Vernonieae. In: Funk VA, Susanna A, Stuessy T \& Bayer RJ (eds.) Systematics, evolution and biogeography of the Compositae. IAPT, Vienna. Pp. 439-469.
King RM \& Robinson H(1972) Studies in the Eupatorieae (Compositae). A new genus Pseudobrickellia. Phytologia 24: 74-76.

King RM \& Robinson H (1978) Studies in the Eupatorieae (Asteraceae). A new genus Bejaranoa. Phytologia 40: 51-53.

King RM \& Robinson H (1980a) Studies in the Eupatorieae (Asteraceae). Various new species from Brazil. Phytologia 46: 295-307.

King RM \& Robinson H (1980b) Studies in the Eupatorieae (Asteraceae). A review of the genus Stylotrichium. Phytologia 45: 101-103.

King RM \& Robinson H (1987) The genera of Eupatorieae (Asteraceae). Monographs in Systematic Botany from the Missouri Botanical Garden 22: 1-581.

Kirkman LK (1981) Taxonomic revision of Centratherum and Phyllocephallum (Compositae: Vernonieae). Rhodora 83: 1-24.

Leitão-Filho HF \& Semir J (1987) Compositae. In: Giulietti AM., Menezes N, Pirani J, Meguro M \& Wanderley M (eds.) Flora da Serra do Cipó, Minas Gerais: caracterização e lista de espécies. Vol. 9. Boletim de Botânica da Universidade de São Paulo, São Paulo. Pp. 29-41.

Loeuille B (2011) Towards a Phylogenetic Classification of Lychnophorinae (Asteraceae: Vernonieae). Tese de Doutorado. Universidade de São Paulo, São Paulo. 433p.

Loeuille B, Lopes JC \& Pirani JR (2012a) Taxonomic novelties in Eremanthus (Compositae: Vernonieae) from Brazil. Kew Bulletin 67: 1-9.

Loeuille B, Semir J \& Pirani JR (2012b) A new species of Paralychnophora (Asteraceae: Vernonieae), and comments on the identity of Paralychnophora bicolor. Britonia 64: 289-295.

Loeuille B, Siniscalchi CM \& Pirani JR (2014) New names in Vernonieae (Asteraceae) of Northeastern Brazil. Phytoneuron 9: 1-11.

Macleish NFF (1984) Argyrovernonia e Paralychnophora: new names in the tribe Vernonieae (Astereaceae/Compositae). Taxon 33: 105-106.

Macleish NFF (1987) Revision of Eremanthus (Compositae: Vernonieae). Annals of the Missouri Botanical Garden 74: 265-290.

Maury CM (2002) Avaliação e identificação de áreas e ações prioritárias para conservação, utilização sustentável e repartição de benefícios da biodiversidade brasileira. Brasília, Ministério do Meio Ambiente. 404p.

MMA - Ministério do Meio Ambiente (2007) Divisão política do Brasil por municípios. Disponível em $<$ http://mapas.mma.gov.br/i3geo/datadownload. htm $>$. Acesso em 25 julho 2018.

Moura L \& Roque N (2014) Asteraceae no município de Jacobina, Chapada Diamantina, estado da Bahia, Brasil. Hoehnea 41: 573-587. 
Nakajima JN, Dematteis M, Loeuille B, Teles AM, Heiden G, Schneider A, Ritter M, Oliveira CT, Hattori EKO, Roque N, Ferreira SC, Magenta M, Bringel Jr JBA, Esteves R, Almeida GSS, Saavedra MM, Monge M, Soares PN, Sancho G, Mondin CA, Fernandes AC, Pereira ACM, Kutschenko DC, Santos Filho LAF, Prieto PV, Borges RAX, Penedo TSA, Messina T, Moraes MMV, Moraes MA, Coelho MAN (2013) Asteraceae. In: Martinelli G \& Moraes MA (eds.) Livro Vermelho da Flora do Brasil. Centro Nacional de Conservação da Flora, Rio de Janeiro. Pp. 204-286.

Ogasawara HA \& Roque N (2015) Flora da Bahia: Asteraceae - subtribo Vernoniinae. Sitientibus, Série Ciências Biológicas 15: 1-24.

Panero JL \& Crozier BS (2016) Macroevolutionary dynamics in the early diversification of Asteraceae. Molecular Phylogenetics and Evolution 99: 116132.

Peixoto AL \& Maia LC (2013) Manual de procedimentos para herbários. Ed. Universitária da UFPE, Recife. $97 \mathrm{p}$.

Pirani JR, Mello-Silva R \& Giulietti AM (2003) Flora de Grão Mogol, Minas Gerais, Brasil. Boletim de Botânica da Universidade de São Paulo 21: 1-24.

Queiroz LP, Conceição A \& Giulietti AM (2006) Nordeste semiárido: caracterização geral e lista das fanerógamas. In: Giulietti AM \& Queiroz LP (orgs.) Instituto do Milênio do Semiárido: diversidade e caracterização das fanerógamas do semiárido brasileiro. Vol. 1. APNE, Recife. Pp. 15-364.

Radford AE, Dickison WC, Massey JR \& Bell CR (1974) Vascular plant systematics. Harper \& Row Pub., New York. 891p.

Ritter MR \& Miotto STS (2005) Taxonomia de Mikania Willd. (Asteraceae) no Rio Grande do Sul, Brasil. Hoehnea 32: 309-359.

Rivera VL, Panero JL, Schilling EE, Crozier BS \& Moraes MD (2016) Origins and recent radiation of Brazilian Eupatorieae (Asteraceae) in the eastern Cerrado and Atlantic Forest. Molecular Phylogenetics and Evolution 97: 90-100.

Robinson H (1979) New species of Vernonieae (Asteraceae) II. Five new species of Vernonia from Bahia. Phytologia 44: 287-288.

Robinson H (1980) New species of Vernonieae (Asteraceae) V. Additions to Vernonia from Brasil. Phytologia 45: 166-208.

Robinson H (1987) Studies in the Lepidaploa complex (Vernonieae: Asteraceae). III. Two new genera, Cyrtocymura and Eirmocephala. Proceedings of the Biological Society of Washington 100: 844-855.

Robinson H (1988) Studies in the Lepidaploa complex (Vernonieae: Asteraceae) V. The new genus Chrysolaena. Proceedings of the Biological Society of Washington 101: 952-958.

Robinson H (1990) Studies in the Lepidaploa Complex (Vernonieae: Asteraceae) VII. The genus
Lepidaploa. Proceedings of the Biological Society of Washington 103: 464-465.

Robinson H (1999) Generic and subtribal classification of american Vernonieae. Smithsonian contributions to Botany. Vol. 89. Smithsonian Institution Press, Washington, D.C. Pp. 1-116.

Robinson H (2002) Three new species of Piptocarpha (Asteraceae: Vernonieae) from Ecuador and Peru. Novon 12: 393-398.

Rocha AJD \& Costa IVG (1995) Projeto mapas municipais - município de Morro do Chapéu (BA): informações básicas para o planejamento e administração do meio físico. Ministério de Minas e Energia Companhia de Pesquisa de recursos Minerais. Prefeitura de Morro do Chapéu-BA, Salvador. 287p.

Roque N \& Bautista HP (2007) Redescoberta de Scherya bahiensis R.M.King \& H.Rob. (Compositae) na Chapada Diamantina, Bahia, Brasil. Boletim de Botânica da Universidade de São Paulo 25: 143145 .

Roque N \& Bautista HP(2008)Asteraceae: Caracterização e morfologia floral. EDUFBA, Salvador. 69p.

Roque N, Keil DJ \& Susanna A (2009) Illustrated glossary of Compositae. Appendix A. In: Funk VA, Susanna A, Stuessy T \& Bayer RJ (eds.) Systematics, evolution and biogeography of the Compositae. IAPT, Vienna. Pp. 781-806.

Roque N, Bautista HP \& Mota AC (2012) Taxonomic revision of Trichogonia (Eupatorieae, Asteraceae): a South American genus. Systematic Botany 37: 525-553.

Roque N, Oliveira EC, Moura L, Quaresma AS, Ogasawara HA, Alves M, Santana FA, Heiden G, Caires TA, Bastos NG, Lim GM \& Bautista HP (2016) Asteraceae no município de Mucugê, Chapada Diamantina, Bahia, Brasil. Rodriguésia 67: 125-202.

Roque N, Ferreira SC \& van den Berg C (2017) Lapidia, a new monotypic genus of Asteraceae (Eupatorieae) from Brazil, and its phylogenetic placement. Phytotaxa 291: 1-16.

Small J (1919) The origin and development of the Compositae. New Phytologist: 18: 129-176.

Smith GL (1982) Taxonomic considerations of Piptocarpha (Compositae: Vernonieae) and new taxa in Brazil. Brittonia, New York 34: 210-218.

Smith GL \& Coile NC (2007) Piptocarpha (Compositae: Vernonieae). Flora Neotropica Monographs 99: 1-94.

Staudt MG, Alves M \& Roque N (2017) Asteraceae in the northern Espinhaço Range, Brazil: richness, endemism and conservation. Acta Botanica Brasilica 31: 698-719.

Thiers B [continuamente atualizado] Index Herbariorum: a global directory of public herbaria and associated staff. New York Botanical Garden's Virtual Herbarium. Disponível em $<$ http://sweetgum.nybg. org/science/ih/>. Acesso em 20 abril 2018. 
Zappi DC, Lucas E, Stannard BL, Lughadha EN, Pirani JR, Queiroz LP, Atkins S, Hind DJN, Giulietti AM, Harley RM \& Carvalho AM (2003) Lista das plantas vasculares de Catolés, Chapada Diamantina, Bahia, Brasil. Boletim de Botânica da Universidade de São Paulo 21: 251-400.
Zappi DC (2008) Fitofisionomia da Caatinga associada à Cadeia do Espinhaço. Megadiversidade 4: 33-37. Zugaib M \& Amorim AM (2014) Flora da Bahia: Asteraceae - Piptocarpha (Vernonieae: Pitpotcarphinae). Sitientibus série Ciências Biológicas 14: 10.13102/scb705. 